\title{
ACTIVITIES OF THE WATER RESOURCES DIVISION, CALIFORNIA DISTRICT, FISCAL YEAR 1991
}

Compiled by Myrna L. DeBortoli and Debra A. Grillo

U.S. GEOLOGICAL SURVEY

Open-File Report 92-151

8
0
8 


\section{U.S. DEPARTMENT OF THE INTERIOR \\ MANUEL LUJAN, JR., Secretary}

U.S. GEOLOGICAL SURVEY

Dallas L. Peck, Director

Any use of trade, product, or firm names in this publication is for descriptive purposes only and does not imply endorsement by the U.S. Government.

For sale by:

Books and Open-File Reports Section

U.S. Geological Survey

Federal Center, Box 25425

Denver, CO 80225

For additional information write to:

District Chief

U.S. Geological Survey

Federal Building, Rm W-2233

2800 Cottage Way

Sacramento, CA 95825 


\section{MESSAGE FROM THE DISTRICT CHIEF}

Because California's population has grown and become more diverse during the last few decades, sharing of the State's water resources has become more complex. The ongoing drought emphasizes the limitations of our water resources. Equitable and effective sharing of the State's water resources can be accomplished only through informed water management. We at the California District of the U.S. Geological Survey are committed to conducting systematic and scientific studies and collecting hydrologic data that will provide information relevant to water-resource-sharing issues throughout the State. This report summarizes ongoing research, investigation, and data-collection activities.

Research, investigation, and data collection in southern California are focused to a large extent on the supply and quality of ground water. Critical issues and information needs are related to the effects of ground-water pumpage. Land subsidence, fissures, and potholes at Edwards Air Force Base and seawater intrusion in coastal aquifers in Ventura County are examples of negative effects caused by ground-water pumpage. Two ongoing projects in the Edwards Air Force Base and Ventura County areas are focused on understanding, quantifying, and evaluating options for mitigating the negative effects of ground-water pumpage.

Ground-water quality is another issue of concern in the southern part of the State where high concentrations of nitrate, organic contaminants, and trace elements affect the usability of ground water. Survey thrust programs, the National Water Quality Assessment program in the San Joaquin Valley, and the Regional Aquifer Systems Analysis of southern California coastal and desert basins are directed towards an understanding of hydrologic and geochemical processes that affect ground-water quality. Three projects being done in cooperation with State and local agencies--"Interaction of ground-water flow at different scales in the western San Joaquin Valley," "Nitrate in the Hemet subbasin," and "Processes governing the distribution of selenium and arsenic in the Tulare Basin"--address the processes that affect the distribution of trace elements and nitrate in ground water.

In northern California, the Sacramento-San Joaquin Delta is the focus of two critical issues of concern: (1) possible alteration of flow patterns in the delta and San Francisco Bay due to delivery of water to southern California and (2) water-quality changes of the bay/delta system due to contamination by agricultural, industrial, and municipal inputs into the system, and the effects of this bay/delta water on aquatic life and municipal users. The combined efforts of the cooperative project "Estimating tidal and residual circulation in San Francisco Bay" and the U.S. Geological Survey funded "San Francisco BayEstuary toxic contaminants study" are focused on understanding the processes that affect the flow of water and concentration of organic contaminants in the bay/delta system.

Because of the multifaceted nature of the bay/delta problem and other water-related problems throughout the State, the approach of many of the studies described in the report is interdisciplinary and requires (1) the participation of well-trained professionals willing to interact and learn from each other's fields and (2) that the search for solutions takes precedence over traditional disciplinary boundaries. The interdisciplinary data-collection, investigative, and research efforts of the California District, summarized in this report, provide information to the public, policymakers, and water-resource managers.

Steven J. Deverel

Assistant District Chief, Northern California 


\section{CONTENTS}

U.S. Geological Survey origin 1

Water Resources Division basic mission and program 2

California District organization 2

California District addresses 4

California District funding 6

Water conditions 9

Project descriptions:

CA001 Surface-water stations 14

CA002 Ground-water stations 16

CA003 Water-quality stations $\mathbf{1 8}$

CA004 Sediment stations $\mathbf{2 0}$

CA005 National trends network for monitoring atmospheric deposition 21

CA007 Water-use information for California $\mathbf{2 2}$

CA027 Ground-water appraisal, U.S. Marine Corps Base, Twentynine Palms 23

CA030 Appraisal of ground-water resources, Indian Wells Valley 24

CA184 Characterization of the quality of water resources of Santa Clara County 25

CA271 Characteristics of flooding and channel changes of the Sacramento River between Hamilton City and Butte City 26

CA342 Ground-water resources of the Santa Barbara area 27

CA419 Estimating tidal and residual circulation in San Francisco Bay 28

CA424 Southern California Regional Aquifer-System Analysis 29

CA431 Hydrologic studies related to volcanic activity in Long Valley $\mathbf{3 1}$

CA459 Investigation of land subsidence, Sacramento Valley; application of a new technique for investigation of land subsidence $\mathbf{3 3}$

CA466 Evaluation of ground-water contamination from nonpoint sources using solute-transport techniques $\mathbf{3 5}$

CA467 Optimum management in a basin with changing water-supply and water-quality problems 36

CA469 Rainfall and runoff in the Antelope Valley drainage area 38

CA470 Detailed study and assessment of irrigation drainage in the Salton Sea area, Imperial Valley $\mathbf{4 0}$

CA472 Changes in runoff in Perris Valley, Riverside County 41

CA473 Water resources and geohydrology of the city and county of San Francisco $\mathbf{4 2}$

CA474 Ground-water hydraulics in Wolf Valley, Riverside County 44

CA475 Effects of nonpoint source runoff from Alameda County on South San Francisco Bay 46

CA476 Development of Sacramento River bed-scour relation at the SR-32 bridge at Hamilton City 47

CA477 Ground-water resource investigations, Edwards Air Force Base 48

CA479 Evaluation of subsidence rates and processes in surficial peat, Sacramento-San Joaquin Delta 50

CA480 Nitrate in the Hemet ground-water subbasin $\mathbf{5 2}$

CA481 Processes governing the distribution and mobility of selenium and arsenic in shallow ground water, Tulare basin $\mathbf{5 3}$

CA482 Interaction of ground-water flow at regional, subregional, and farm scales, and implications for drainwater flow and quality, western San Joaquin Valley $\mathbf{5 5}$

CA483 Optimum control of seawater intrusion, Oxnard Plain, Ventura County 57

CA484 San Francisco Bay-Estuary toxic contaminant study $\mathbf{5 8}$

CA485 San Joaquin-Tulare basins National Water Quality Assessment Program 60 
Project descriptions--Continued

CA486 Appraisal of water resources in the Wawona area of Yosemite National Park with emphasis on the availability of ground water 62

CA487 Water resources of Indian reservations in California 63

CA488 Assessment of the effects of potential climate change on the water resources of the Carson and American River basins 64

CA489 Irrigation drainage detailed study of Klamath Basin, California and Oregon 66

Bibliography 68

Sources of WRD publications and information 73

Where to obtain additional information on U.S. Geological Survey programs 74

Where to obtain additional information on U.S. Geological Survey reports 74

\section{FIGURES}

1. Organization chart for the California District, 1991 3

2. Map showing location of offices in the California District, 19915

3, 4. Diagrams showing:

3. Sources of California District funds in fiscal year 19918

4. Categories of investigations in the California District, by funding, fiscal year 19918

5, 6. Graphs showing:

5. Monthly streamflow for water years 1990 and 1991 compared with median monthly streamflow, 1951-80, at six Califormia index stations 10

6. Departure from the sum of total median monthly streamflow at six California index stations 11

7. Total storage, by months, at six large California reservoirs $\mathbf{1 2}$

\section{TABLE}

1. Summary of water conditions in California, 19919 


\section{U.S. GEOLOGICAL SURVEY ORIGIN}

The U.S. Geological Survey (USGS) was established by an act of Congress on March 3, 1879, to provide a permanent Federal agency to conduct the systematic and scientific "classification of the public lands, and examination of the geological structure, mineral resources, and products of national domain." An integral part of that original mission includes publishing and disseminating the earth-science information needed to understand, to plan the use of, and to manage the Nation's energy, land, mineral, and water resources.

Since 1879 , the research and factfinding role of the USGS has grown and been modified to meet the changing needs of the Nation. As part of that evolution, the USGS has become the Federal Government's most comprehensive earth-science research agency, the Nation's largest civilian mapmaking agency, the primary source of data on the Nation's surface- and ground-water resources, and the employer of the largest number of professional earth scientists. Today's programs serve a diversity of needs and users. Programs include:

- Assessing the energy and mineral potential of the Nation's land and offshore areas.

- Geologic risk assessment, including issuing warnings of earthquakes, volcanic eruptions, landslides, and other geologic and hydrologic hazards.

- Conducting research on the tectonics of the Earth.

- Stuciying the geologic features, structure, processes, and history of the other planets of our solar system.

- Conducting topographic surveys and preparing topographic and thematic maps and related cartographic products.

- Developing and producing digital cartographic data bases and products.

- Collecting data on a routine basis to determine the quantity, quality, and use of surface and ground water.

- Conducting water-resource appraisals in order to describe the consequences of alternative plans for developing land and water resources.

- Conducting research in ground- and surface-water hydrology and hydraulics and coordinating waterdata acquisition with other Federal agencies.

- Using remotely sensed data to develop new cartographic, geologic, and hydrologic research techniques for natural-resources planning and management.

- Providing earth-science information through an extensive publications program and a network of public-access points.

Along with its continuing commitment to meet the growing and changing earth-science needs of the Nation, the USGS remains dedicated to its original mission to collect, analyze, interpret, publish, and disseminate information about the natural resources of the Nation--providing "Earth science in the public service." 


\section{WATER RESOURCES DIVISION BASIC MISSION AND PROGRAM}

The mission of the Water Resources Division (WRD) is to provide the hydrologic information and understanding needed for the optimum use and management of the Nation's water resources. To accomplish this mission, the WRD, in cooperation with local, State, and Federal agencies, uses a wide variety of techniques to collect and interpret hydrologic information and to transfer that information to the water-user community. An integral part of that mission includes publishing and disseminating the earth-science information needed to understand, plan the use of, and manage the Nation's energy, land, mineral, and water resources.

This is accomplished, in large part, through cooperation with other Federal and non-Federal agencies, by:

- Systematically collecting data needed for evaluating the quantity, quality, and use of the Nation's water resources.

- Conducting analytical and interpretive water-resources appraisals of the occurrence, availability, and physical, chemical, and biological characteristics of surface and ground water.

- Conducting basic and applied research in hydraulics, hydrology, and water chemistry, solute transport, and hydraulic modeling to improve the scientific basis for investigations and measurement techniques and to understand hydrologic systems sufficiently well to quantitatively predict their response to stress, either natural or manmade.

- Disseminating the water data and the results of these investigations and research through reports, maps, computerized information services, and other forms of public releases.

- Coordinating with other Federal agencies in the acquisition of water data for streams, lakes, reservoirs, estuaries, and ground water.

- Providing scientific and technical assistance in hydrology fields to other Federal, State, and local agencies, to licensees of the Federal Energy Regulatory Commission, and to International agencies on behalf of the Department of State.

\section{CALIFORNIA DISTRICT ORGANIZATION}

The headquarters for the California District is in Sacramento. Hydrologic investigations and data collection are conducted from 2 project offices and 10 field offices. These offices and supporting units of the District are shown in the organization chart (fig. 1). 


\section{CALIFORNIA DISTRICT}

U.S. Geological Survey

Water Resources Division

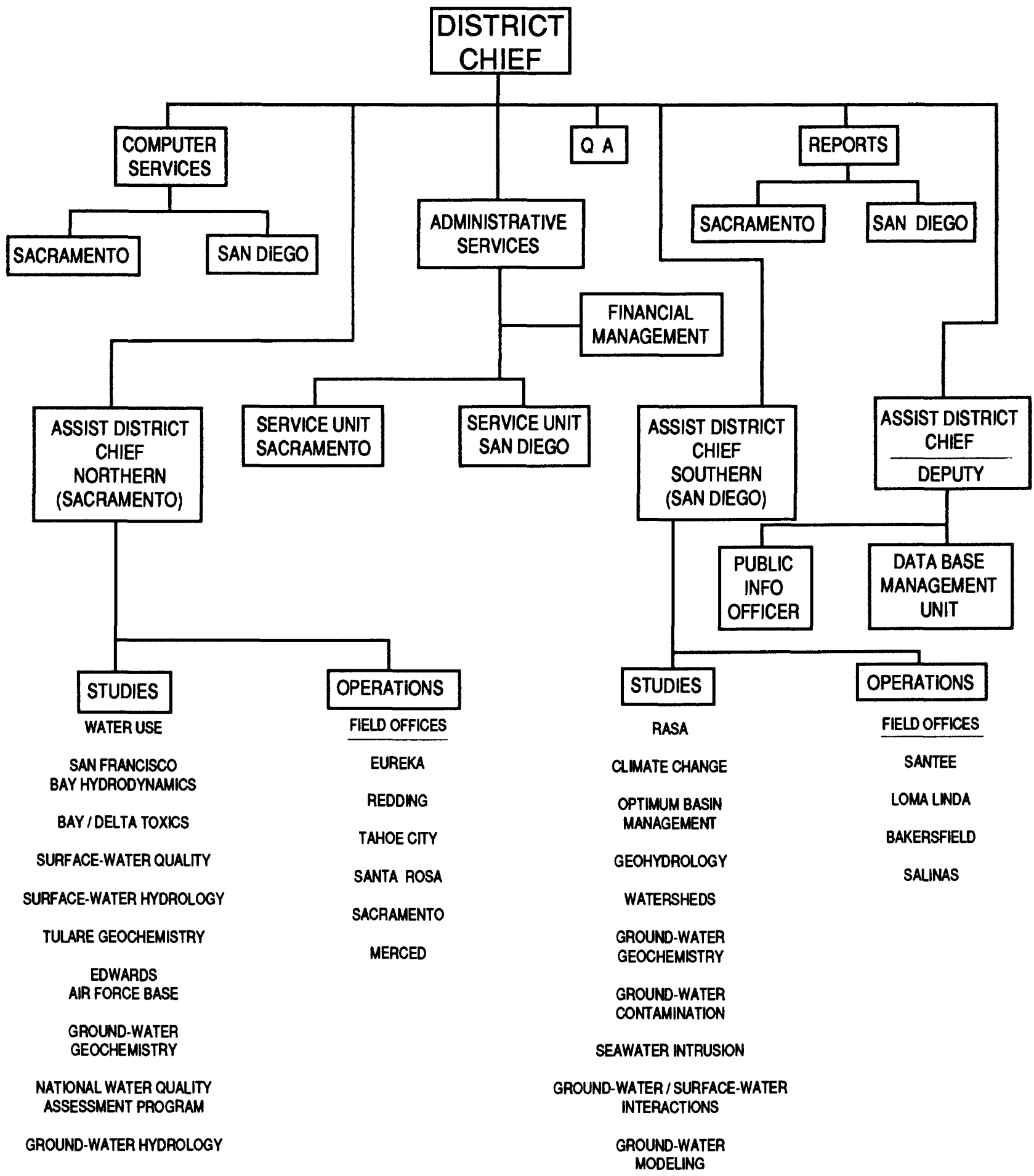

Figure 1. Organization chart for the California District, 1991. 


\section{CALIFORNIA DISTRICT ADDRESSES}

Inquiries regarding projects described in this report may be directed to the District Office. Addresses for the offices of the District Chief and Assistant District Chief and field offices are listed below. Location of offices are shown in figure 2 .

\section{DISTRICT CHIEF \\ (916) 978-4633}

\section{ASSISTANT DISTRICT CHIEFS}

Sacramento

(916) 978-4648

San Diego

(619) $557-6700$

\section{FIELD OFFICES}

Bakersfield

(805) $861-4347$

Eureka

Loma Linda

Merced

Redding

Sacramento

Salinas

Santa Rosa

Santee

Tahoe City
(707) $443-2028$

Office closed May 1992

(209) 383-9067

(916) $246-5282$

(916) $978-4658$

(408) 754-6717

(707) $576-1740$

(619) $557-5155$

(916) $583-4823$
U.S. Geological Survey 2800 Cottage Way, Rm W-2233

Sacramento, CA 95825

2800 Cottage Way, Rm W-2233

Sacramento, CA 95825

5735 Kearny Villa Road, Suite O

San Diego, CA 92123

3131 Pegasus Drive Bakersfield, CA 93308

1105 6th Street Eureka, CA 95501

1547 Yosemite Parkway Merced, CA 95340

11075 Black Marble Way Redding, CA 96003

2800 Cottage Way, Rm W-2233

Sacramento, CA 95825

P.O. Box 5027

Salinas, CA 93915

5 West 9th Street, \#2

Santa Rosa, CA 95401

10130 Mission Gorge Road Santee, CA 92071

605 Westlake Boulevard Tahoe City, CA 95730 


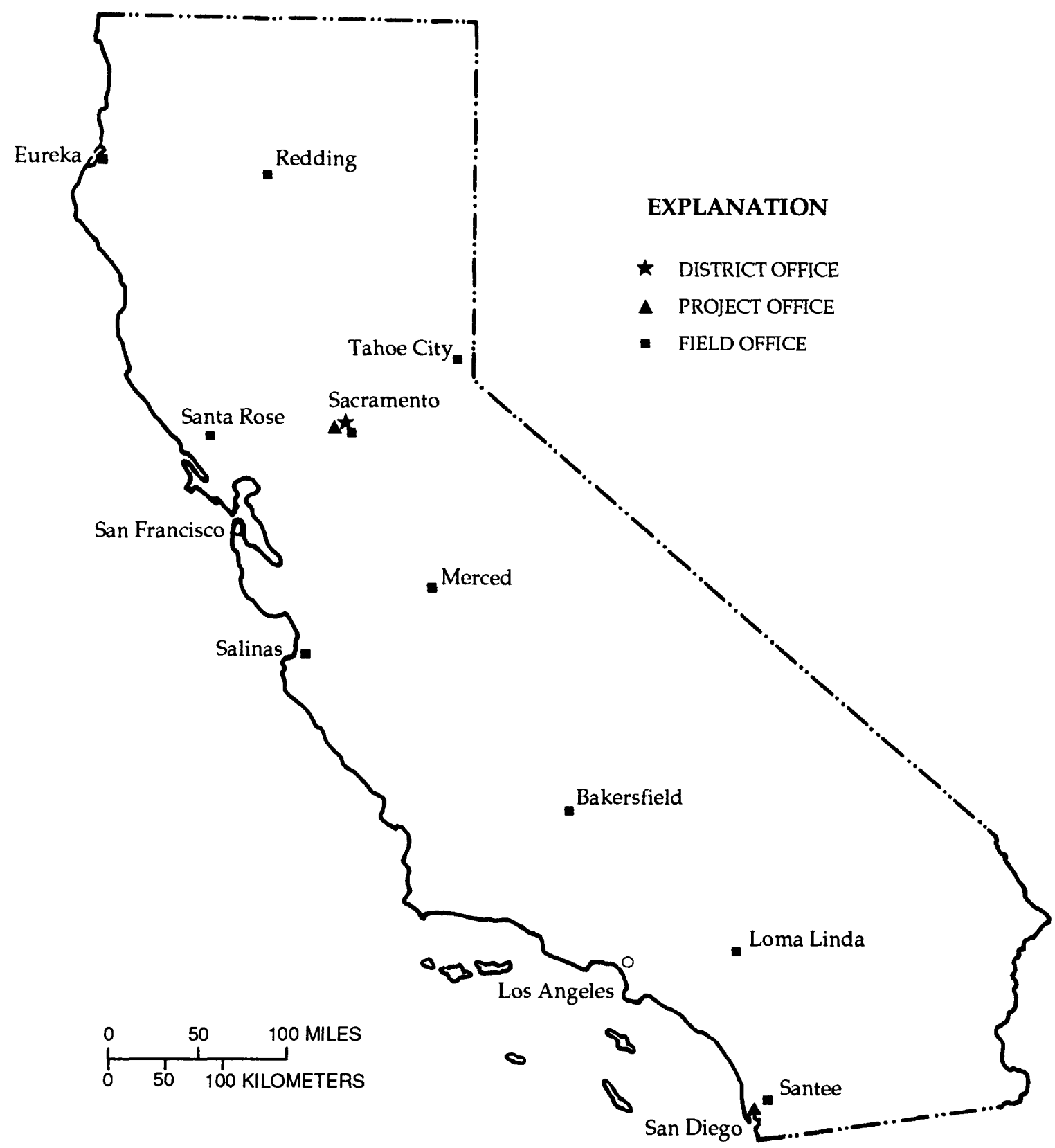

Figure 2. Location of offices in the California District, 1991. 


\section{CALIFORNIA DISTRICT FUNDING}

Programs of the Water Resources Division in Califomia are funded as follows: (1) the Federal program, which is specifically identified in annual Geological Survey appropriations made by Congress; (2) the Federal-State cooperative program, where the Water Resources Division represents national interest, the cooperating agencies represent State and local interest, and the funding generally is shared equally (the Federal share comes from direct Congressional appropriations); and (3) the Other-Federal-Agencies (OFA) Program, which is funded by Federal agencies. Total funds and sources of funding for fiscal year 1991 are shown in figure 3. [The fiscal year (FY) is from October 1 to September 30 and is designated by the calendar year in which it ends.]

The percentages for investigations, by funding, for fiscal year 1991 in each of the broad categories of hydrologic-data collection, areal appraisals and interpretive studies, and research projects are shown in figure 4.

In fiscal year 1991, State, local, and Federal agencies contributed funds or services or both in cooperative programs with the California District. Organizations that assisted the Survey through cooperative agreement are

\section{State Agencies}

California Department of Boating and Waterways

California Department of Food and Agriculture California Department of Parks and Recreation Califormia Department of Transportation Califomia Department of Water Resources California State Water Resources Control Board Califormia Regional Water Quality Control Board Central Valley Region Lahontan Region

\section{Local Agencies}

Alameda County Flood Control and Water Conservation District

Alameda County Water District

Antelope Valley-East Kern Water Agency

Calaveras County Water District

Carpenteria County Water District

Casitas Municipal Water District

Coachella Valley Water District

Contra Costa County Flood Control and Water Conservation District

Crestline-Lake Arrowhead Water Agency

Desert Water Agency

East Bay Municipal Utility District

Eastern Municipal Water District

East Valley Water District

Five Bears Hydroelectric

Fox Canyon Groundwater Management Agency

Georgetown Divide Public Utility District

Humboldt Bay Municipal Water District

Imperial County Department of Public Works
Local Agencies--Continued

Imperial Irrigation District

Independent Hydro Developers

Indian Wells Valley Water District

Los Angeles County Department of Public Works

Madera Irrigation District

Marin Municipal Water District

Mendocino County Water Agency

Merced, city of

Merced Irrigation District

Mojave Water Agency

Mono County

Montecito Water District

Monterey County Water Resources Agency

Monterey Peninsula Water Management District

Nelson Creek Power Company

Nevada Irrigation District

North Kern Water Storage District

Oakdale-South San Joaquin Irrigation District

Olcese Water District

Orange County Water District

Oroville-Wyandotte Irrigation District

Pacific Gas \& Electric Company

PacificCorp

Pala Band of Mission Indians

Palo Alto, city of

Panoche Water and Drainage District

Pechanga Indian Reservation

Placer County Water Agency

Rancho California Water District

Riverside County Flood Control and Water

Conservation District

Rock Creek Limited Partnership

Sacramento Municipal Utility District

Sacramento County Regional Sanitation District 
Local Agencies--Continued

San Benito County Water District

San Bernardino County Flood Control District

San Bernardino Valley Municipal Water District

San Diego, city of

San Diego County Department of Public Works

San Francisco, city and county of,

Hetch Hetchy Water and Power

San Francisco Water Department

San Luis Obispo County Engineering Department

San Mateo County

Santa Barbara, city of

Santa Barbara County Flood Control and Water Conservation District

Santa Barbara County Water Agency

Santa Clara Valley Water District

Santa Cruz, city of

Santa Cruz County Flood Control and Water Conservation District

Santa Maria Valley Water Conservation District

Santa Ynez River Water Conservation District

Scotts Valley Water District

Sonoma County Planning Department

Sonoma County Water Agency

South Sutter Water District

Southern California Edison Company

STS Hydropower Ltd.

Synergics, Inc.

Tahoe Regional Planning Agency

Tulare County Flood Control District

Tuolumne County

Turlock Irrigation District

United Water Conservation District
Local Agencies--Continued

Ventura County Public Works Agency

Woodbridge Irrigation District

Yolo County Flood Control and Water Conservation District

Yuba County Water Agency

Federal Agencies

U.S. Department of Agriculture Forest Service

U.S. Department of the Air Force Edwards Air Force Base Vandenberg Air Force Base

U.S. Department of the Army

Corps of Engineers

Los Angeles District

Sacramento District

San Francisco District

U.S. Department of the Interior Bureau of Indian Affairs Bureau of Reclamation National Park Service

U.S. Environmental Protection Agency

U.S. Navy

Marine Corps Air Ground Combat Center, Twentynine Palms

Marine Corps Base, Camp Pendleton

Naval Air Station, Point Mugu 


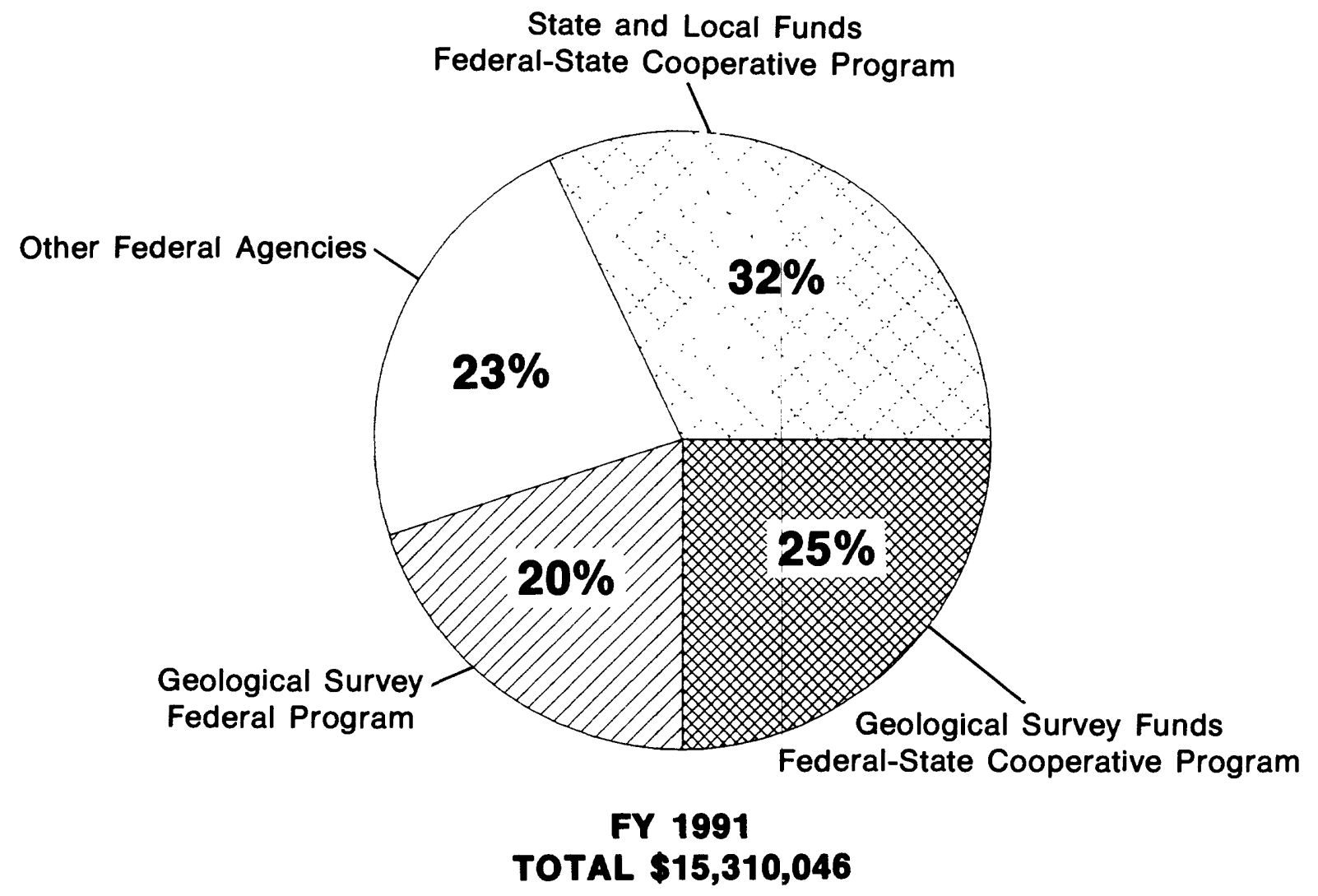

Figure 3. Sources of California District funds in fiscal year 1991.

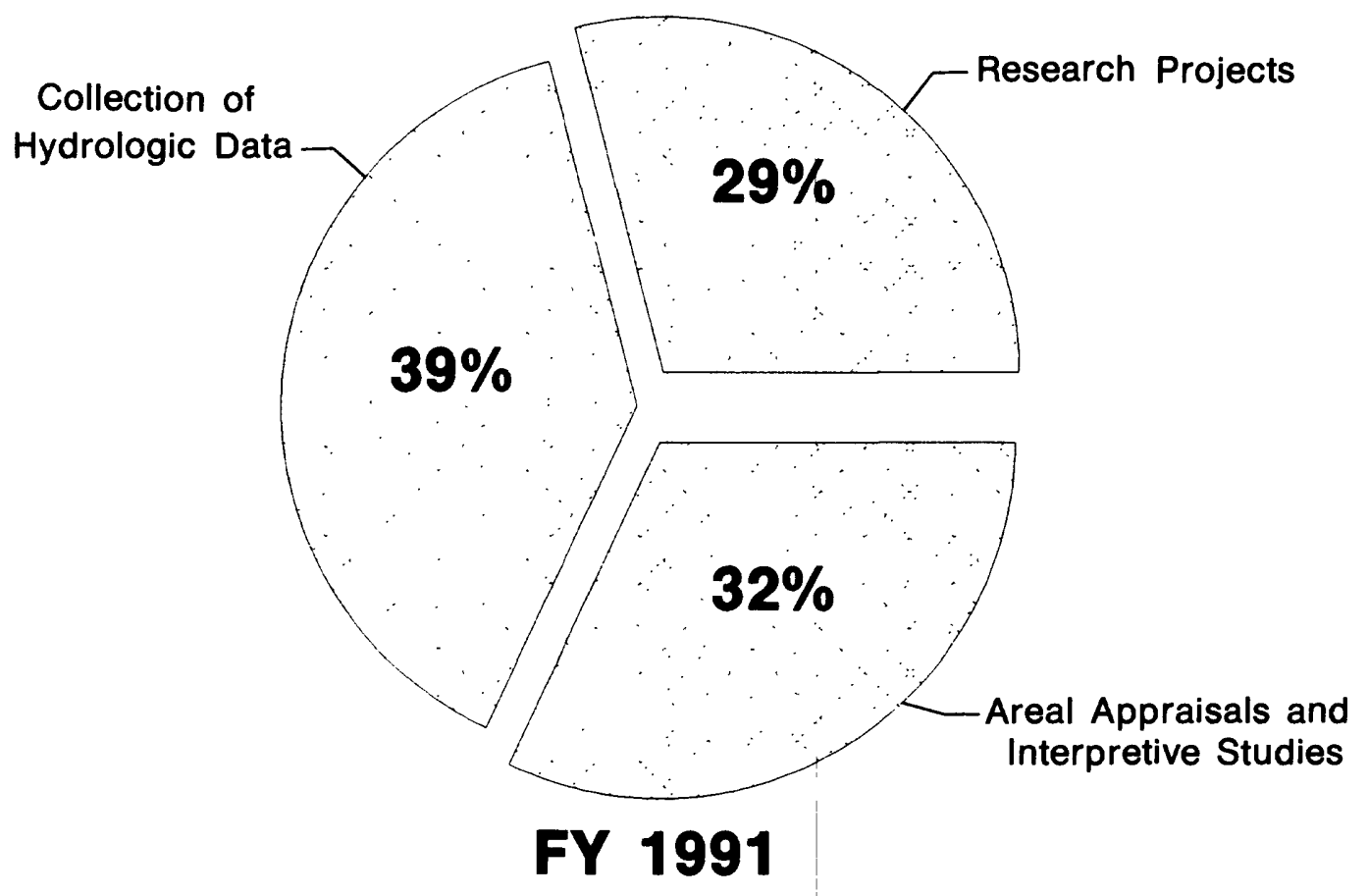

Figure 4. Categories of investigations in the California District, by funding, fiscal year 1991. 


\section{WATER CONDITIONS}

At the end of the 1991 water year, the accumulated effects of 5 consecutive years of drought in California include below average streamflow in most of the hydrologic regions of the State, below average storage in the State's reservoirs, and declining ground-water levels in the State's aquifers caused by an increase in ground-water pumping to supplement reduced surface-water supplies.

Although 1987 marks the beginning of the current period of drought, water-supply problems were minimal in 1987 because of the surface-water in storage from 1986 and earlier years. The most serious problems in 1987 affected the wetlands and nonirrigated agriculture. During 1988 and the first half of 1989, water shortages affected about one-third of the State's population and more than 40 percent of irrigated agriculture. Water-supply problems were especially difficult in areas where ground-water reservoirs are small (upland and coastal areas). In 1989, the State Water Project and the Federal Central Valley Project announced anticipated reductions of water deliveries of as much as 50 percent. Wet weather in March 1989 brought sufficient precipitation to allow full delivery of agricultural water supplies and the eventual lifting of drought restrictions in much of the State. However, water restrictions continued in the central coast region, which does not receive supplies from any of the major water projects.

In 1990, precipitation brought no drought relief, water deliveries were reduced for the second time in the history of the water projects--the first time was in 1977. The central coast region of the State continued to be the hardest hit by the drought.

In 1991, water-project deliveries were cut or suspended, agricultural and urban areas instituted a broad range of conservation measures, and water banking was created to aid in the transfer of water to areas of need. However, conditions improved significantly (table 1) in the central coast region of the State as a result of a 2 -week series of storms that began on February 28.

The largest water-supply shortages anticipated for 1992 will be to agricultural customers, who will be affected by the depleted reserves of the large water projects. Fortunately, as a result of the March storms of 1991 and water conservation, 1991 carryover of surface water did not decline but remained the same as for the 1990 water year.

Table 1. Summary of water conditions in California, 1991

[From California Department of Water Resources summaries]

\begin{tabular}{|c|c|c|c|c|c|c|}
\hline \multirow{3}{*}{$\begin{array}{l}\text { Hydrologic } \\
\text { region }\end{array}$} & \multicolumn{6}{|c|}{ Percentage of average } \\
\hline & \multicolumn{5}{|c|}{ Runoff (water years) } & \multirow{2}{*}{$\begin{array}{c}\text { Reservoir } \\
\text { storage } \\
\text { Oct. 1, } 1991\end{array}$} \\
\hline & 1987 & 1988 & 1989 & 1990 & 1991 & \\
\hline North Coast & 56 & 52 & 76 & 46 & 35 & 48 \\
\hline San Francisco Bay $\ldots \ldots \ldots \ldots$ & 25 & 26 & 45 & 23 & 48 & 84 \\
\hline Central Coast $\ldots \ldots \ldots \ldots \ldots$ & 19 & 20 & 19 & 9 & 43 & 30 \\
\hline South Coast $\ldots \ldots \ldots \ldots \ldots$ & 32 & 40 & 28 & 16 & 58 & 120 \\
\hline Sacramento Basin & 49 & 49 & 78 & 49 & 45 & 65 \\
\hline San Joaquin Basin $\ldots \ldots \ldots \ldots$ & 33 & 38 & 60 & 40 & 50 & 57 \\
\hline Tulare Lake Basin $\ldots \ldots \ldots \ldots$ & 45 & 42 & 50 & 34 & 56 & 42 \\
\hline North Lahontan & 40 & 33 & 78 & 45 & 45 & 17 \\
\hline South Lahontan & 70 & 62 & 64 & 54 & 47 & 77 \\
\hline Colorado River ${ }^{1}$ & 93 & 58 & 41 & 39 & 62 & -- \\
\hline STATEWIDE & 48 & 48 & 70 & 45 & 43 & 61 \\
\hline
\end{tabular}

\footnotetext{
${ }^{1}$ Colorado River inflow to Lake Powell
} 
Monthly streamflow is shown as the sum of six California index stations in figure 5. Monthly streamflow was well below the median through water years 1990 and 1991 except for March 1991 when the effects of the late February-early March storms show streamflow at about 10 percent below the median. The sum of cumulative departure and the monthly percentage of departure from median streamflow of the six California index stations is shown in figure 6. The effect of the drought is shown in the cumulative departure curve which shows that streamflow is more than 20 million acre-feet of water below median, since 1987.

Reservoir storage (table 1) at the end of water year 1991 increased, in part, from 1990, although not significantly. Total reservoir storage on October 1, 1991, was about 60 percent of average, nearly the same as at the end of water year 1990. Fluctuations in month-end storage figures summed for six large reservoirs in the State are compared with the average month-end storage computed through water year 1989 (fig. 7). The sum of storage at the six reservoirs was below average and, for the most part, has been below average since midsummer 1987. Figure 7 compares month-end storage for water years 1974-78

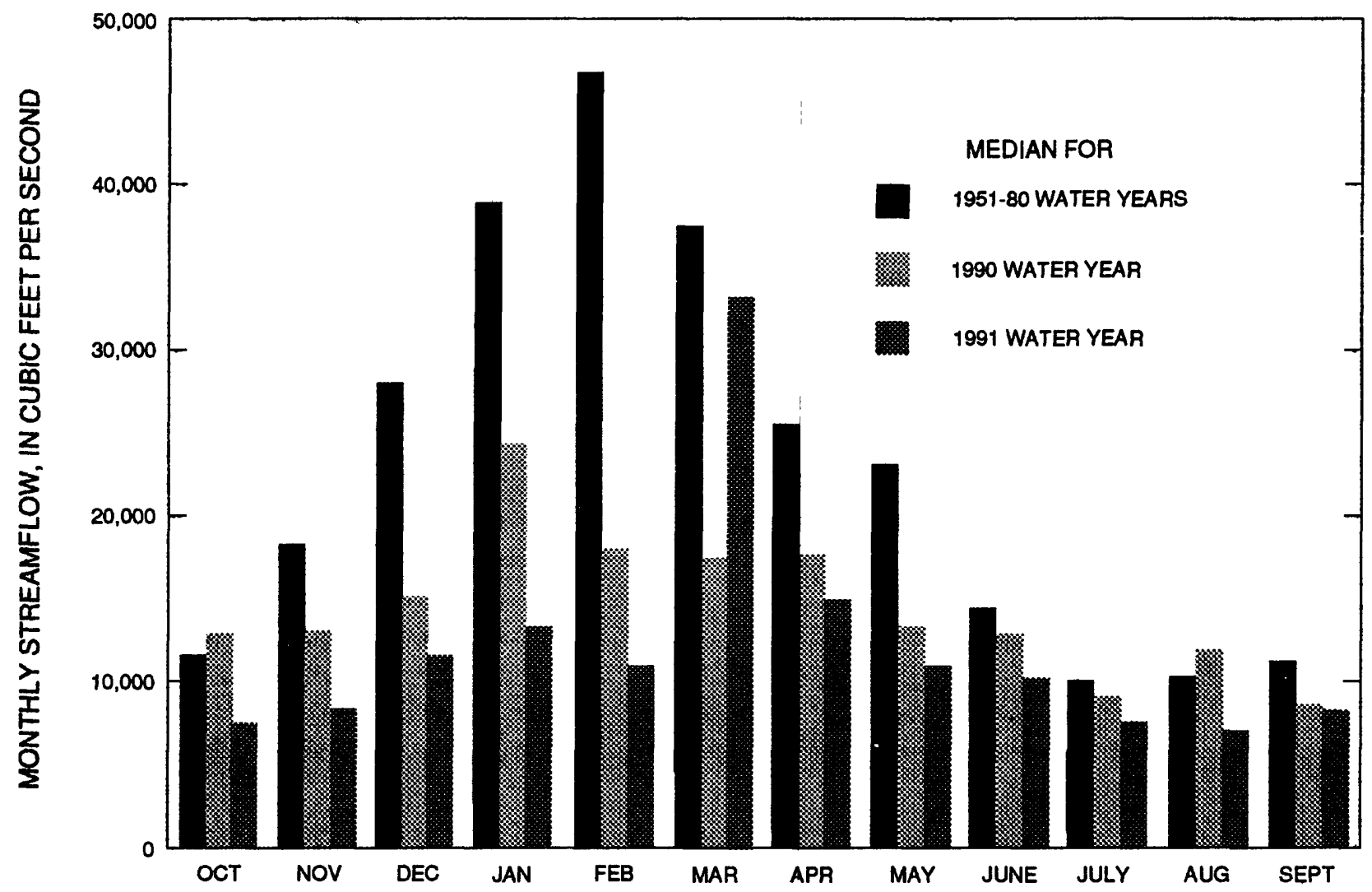

Figure 5. Monthly streamflow for water years 1990 and 1991 compared with median monthly streamflow, 1951-80, at six California index stations. 
and compares the 2-year drought of 1976-77 to the present drought. Month-end storage for the six reservoirs shown in figure 7 was worse during the 1976-77 drought compared with month-end storage for the current drought, although the 1976-77 drought was shorter in duration and ended with the spring rains of 1978. There are some notable, individual exceptions to the pattern shown in figure 7. In March 1991, storms moved from west to east in the middle of the State, producing significant rainfall in the lowlands and snowfall in the high mountains.

If the drought continues into the 1992 water year, carryover storage from 1991 will remain well below average and ground-water resources will continue to be used. The resulting water-level declines in aquifers likely will cause continued land subsidence, areas of deterioration in water quality, and the intrusion of seawater into fresh-water aquifers in coastal areas. The drought will continue to adversely affect fish and wildlife, wildland resources, water quality, hydroelectric power, recreation, agriculture, industry, and personal lifestyles throughout California.

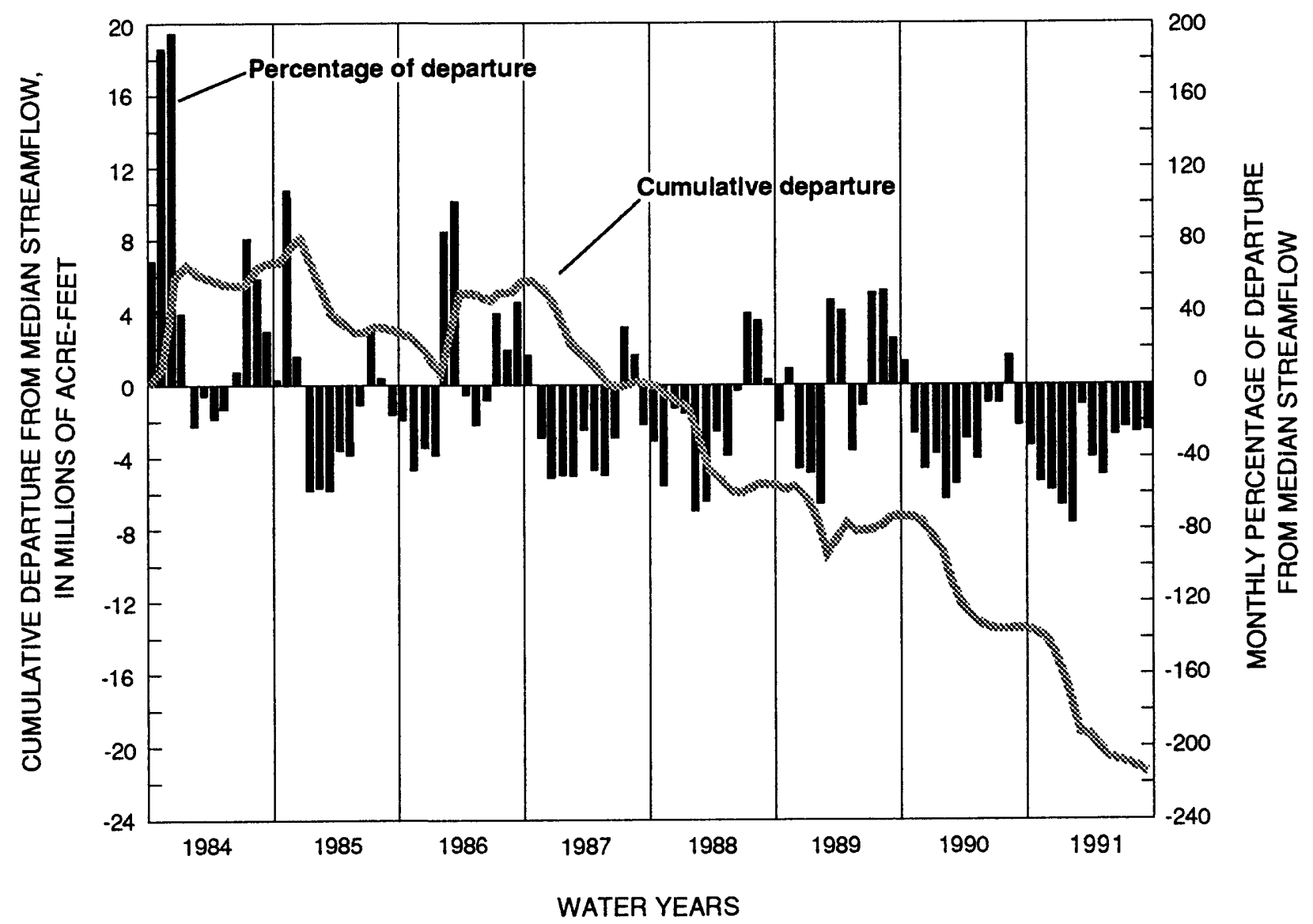

Figure 6. Departure from the sum of total median monthly streamflow at six California index stations. 


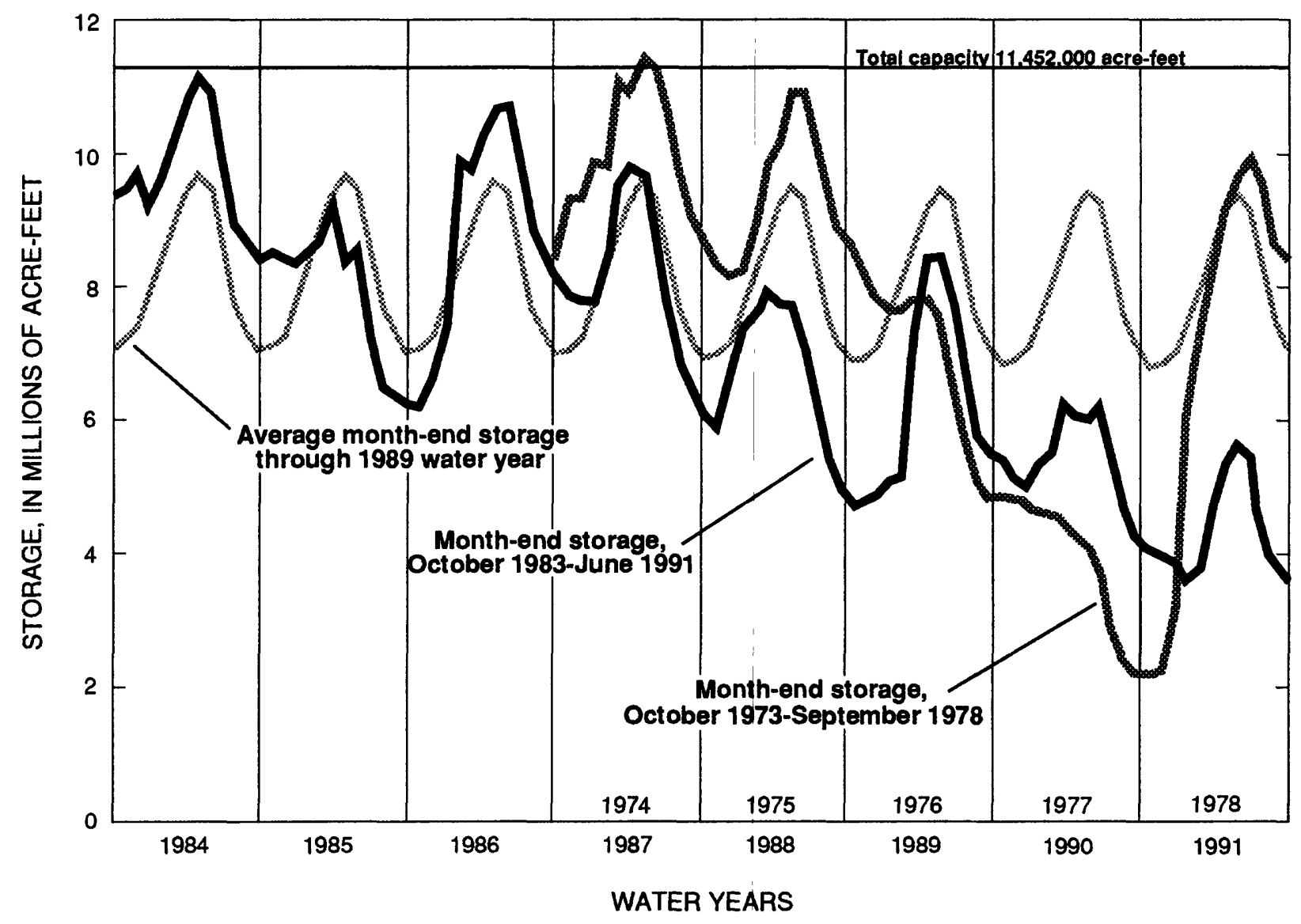

Figure 7. Total storage, by months, at six large California reservoirs. 


\section{PROJECT DESCRIPTIONS}




\section{SURFACE-WATER STATIONS}

Number: CA001

Location: Statewide (See accompanying map)

Project Chief: Kenneth W. Lee

Period of Project: Continuing

Problem: Surface water accounts for about 60 percent of the freshwater withdrawals in California. About one-third of California's population use surface water for domestic supplies. The distribution of surface water is highly variable both seasonally and areally; close monitoring of runoff is essential to the optimum management and development of this resource.

Objectives: Collect and publish surface-water data to meet needs for (1) assessing quantity and distribution of surface-water resources; (2) operating reservoirs for power, flood control, and irrigation; (3) forecasting flow; (4) monitoring of flow for instream-use requirements; (5) determining discharge to support water-quality sampling and assessment programs; (6) determining safe releases of treated reclaimed water to streams and rivers; (7) defining statistical streamflow characteristics needed for research and planning and design of dams, bridges, culverts, canals, flood-management projects, and ground-water-recharge facilities.

Approach: Stage and discharge of streams and stage and contents of lakes and reservoirs will be measured and recorded. Standard methods of data collection will be used as described in the series "Techniques of Water-Resources Investigations of the U.S. Geological Survey." Partial-record data will be collected instead of continuous-record data when it serves the required purpose.

Progress: Additional satellite data-collection platforms were installed and are in operation. Thirty-seven stations are presently equipped with satellite-relay data in transmitters installed by the U.S. Geological Survey. Surface-water data for 768 continuous streamflow stations were collected and compiled for publication. About 200 of these records were provided by other agencies and Federal Energy Regulatory Commission (FERC) licensees. Data were collected or reviewed from 156 reservoir stations. Data were collected and compiled for publication of 105 partial-record stream and reservoir sites that provide peak flow, low flow, seasonal flow, limited range of discharge, or stage information. Data for 1990 were published in four volumes of the annual data-report series.

Plans for Next Year: Statewide data collection and review will continue. Streamflow data will be published in the annual data report for water year 1991.

Reports:

Bowers, J.C., Jensen, R.M., and Hoffman, E.B., 1991, Water resources data--California, water year 1990. Volume 1. Southern Great Basin from Mexican border to Mono Lake basin, and Pacific slope basins from Tijuana River to Santa Maria River: U.S. Geological Survey Water-Data Report CA-90-1, 289 p.

Hunter, T.C., Mullen, J.R., and Anderson, S.W., 1991, Water resources data--California, water year 1990. Volume 3. Southern Central Valley basins and The Great Basin from Walker River to Truckee River: U.S. Geological Survey Water-Data Report CA-90-3, 402 p.

Mullen, J.R., Shelton, W.F., Markham, K.L., and Anderson, S.W., 1991, Water resources data--California, water year 1990. Volume 4. Northern Central Valley basins and The Great Basin from Honey Lake basin to Oregon State line: U.S. Geological Survey Water-Data Report CA-90-4, 323 p.

Shelton, W.F., Trujillo, L.F., Markham, K.L., and Palmer, J.R., 1991, Water resources data--California, water year 1990. Volume 2. Pacific slope basins from Arroyo Grande to Oregon State line except Central Valley: U.S. Geological Survey Water-Data Report CA-90-2, 333 p. 


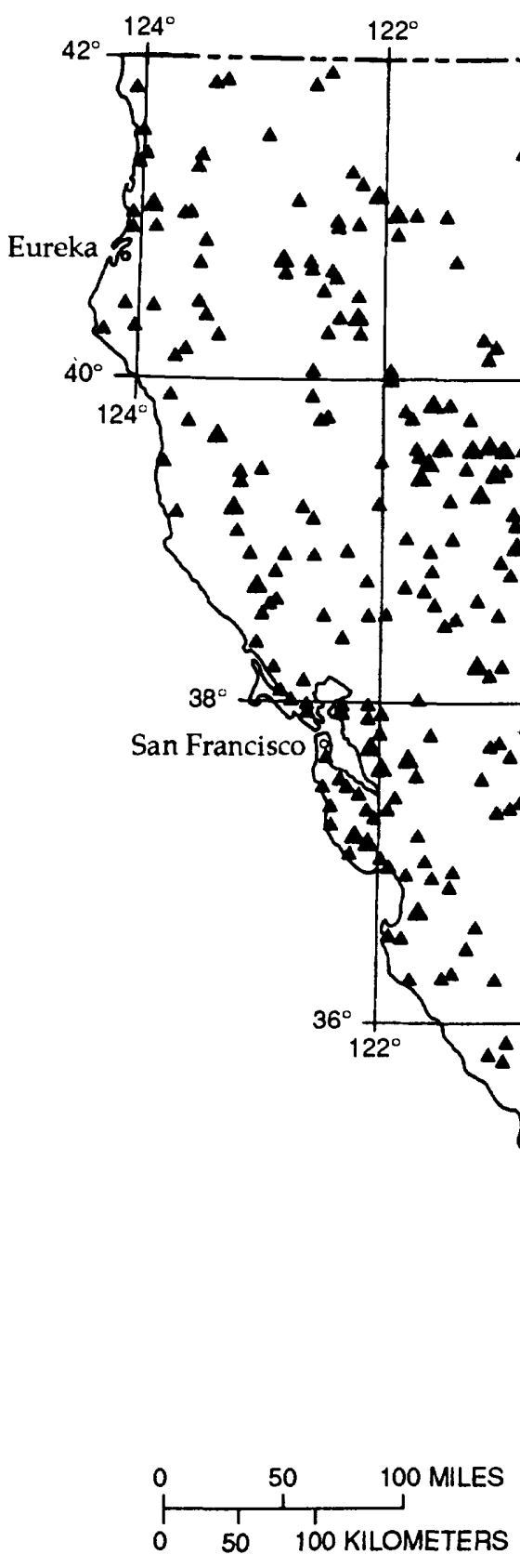

\section{EXPLANATION}

STREAMFLOW OR STAGE STATIONS -

Size of symbol represents indicated range of stations

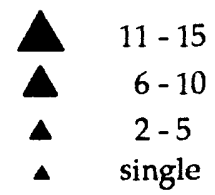




\section{GROUND-WATER STATIONS}

\section{Number: CA002}

Location: Statewide (See accompanying map)

Project Chief: Charles E. Lamb

Period of Project: Continuing

Problem: Ground-water sources supply about 40 percent of the total offstream fresh water used in California. Nearly three-quarters of Califomia's population use ground-water for domestic supplies. Ground-water quality and distribution are highly variable and are related to geologic influences and to natural and manmade stresses. Monitoring of ground-water levels and chemistry is essential to the management and development of the resource.

Objectives: Collect ground-water-level data to meet the needs for assessment of quantity, quality, and occurrence of ground water. These data will be useful to Federal, State, and local water planners.

Approach: Water-level data recorded continuously, monthly, semiannually, and annually will be entered into a computer data base. Standard methods of data collection will be used as described in the "National Handbook of Recommended Methods for Water-Data Acquisition" and Water Resources Division manuals and memorandums.

Progress: Collection and compilation of ground-water-level data continued at 999 long-term sites, 157 short-term sites, and 28 continuous-recorder wells. Data for water year 1990 were published in a separate volume of the annual data-report series.

Plans for Next Year: Data collection and record processing will continue. All processed data for water year 1991 will be published in a separate volume of the annual data-report series.

\section{Reports:}

Johnson, J.A., Fong-Frydendal, L.J., and Baker, J.B., 1991, Water resources data--California, water year 1990. Volume 5. Ground-water data for California: U.S. Geological Survey Water-Data Report CA-90-5, $387 \mathrm{p}$. 


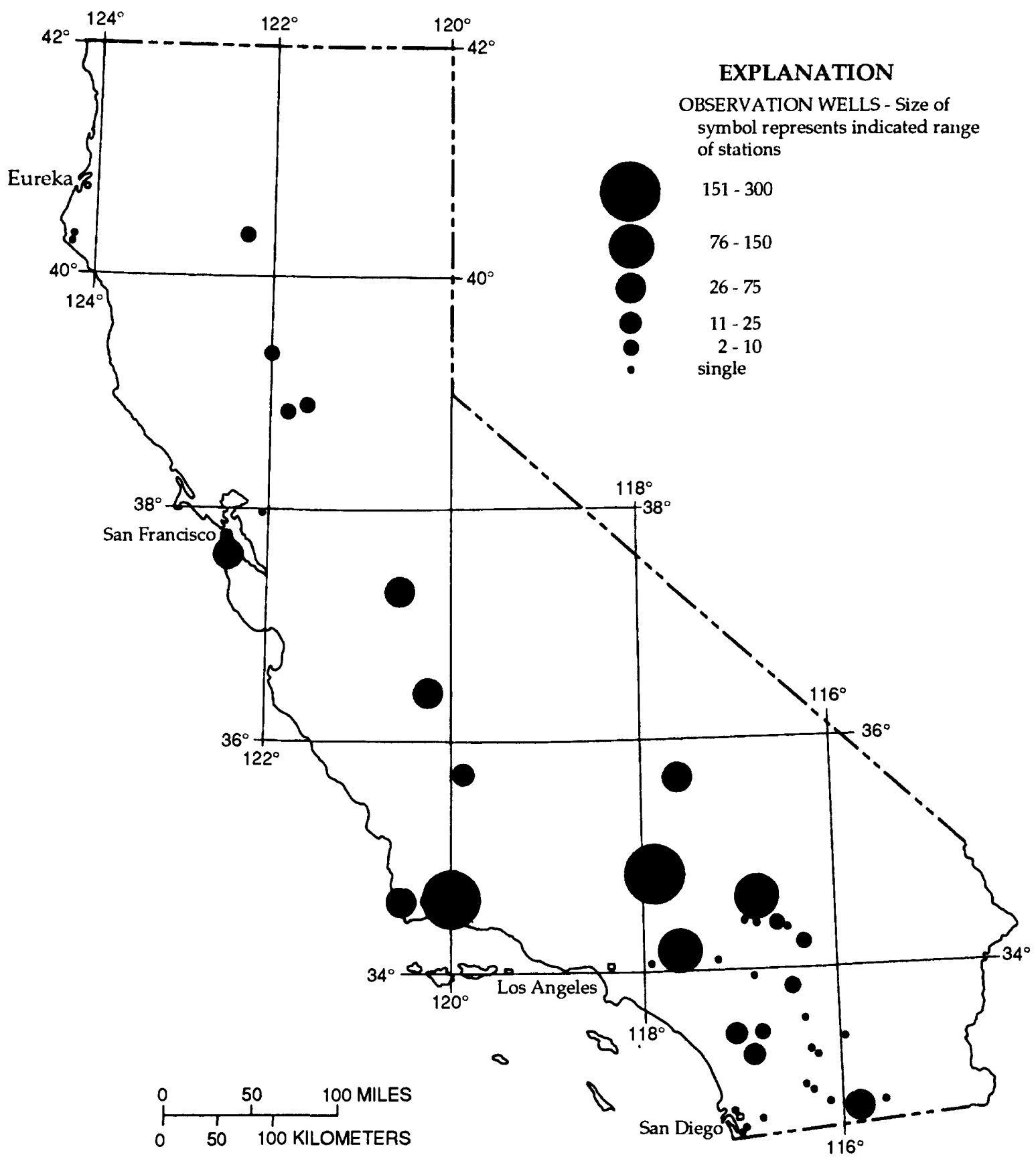

Location of selected observation wells. 


\section{WATER-QUALITY STATIONS}

Number: CA003

Location: Statewide (See accompanying map. Also see map of selected observation wells, page 17)

Project Chief: Rick T. Iwatsubo

Period of Project: Continuing

Problem: In order to properly manage the water resources of the State, the chemical quality of surface and ground water needs to be defined and monitored.

Objectives: Collect and publish long- and short-term records of water quality at selected stream, reservoir, precipitation, and spring sites and ground-water observation wells throughout California. The data will be used by Federal, State, and local agencies in the assessment, management, development, and protection of the State's water resources.

Approach: A network of water-quality sites will be established and operated to provide physical, chemical, and biological data for the objectives stated above. Standard methods of data collection will be used as described in the "National Handbook of Recommended Methods for Water-Data Acquisition" and Water Resources Division manuals and memorandums.

Progress: Water-quality data were collected periodically at many sites throughout California. Water-quality samples were collected bimorithly at 12 and quarterly at 6 NASQAN (National Stream Quality Accounting Network) stations, and quarterly at 3 Hydrologic Benchmark stations. Water temperature and specific conductance were measured continuously at 30 and 7 sites, respectively. Precipitation samples were collected weekly at the National Trends Network stations in the Los Padres National Forest and at Yreka. Water-quality data also were collected at 49 stream and reservoir sites. Chemical analysis were completed for ground-water samples collected from 316 long-term observation wells and 59 short-term observation wells. Data for water year 1990 were published in the annual data-report series.

Plans for Next Year: Collection of water-quality data will continue and the reports for the 1991 water year will be published.

\section{Reports:}

Bowers, J.C., Jensen, R.M., and Hoffman, E.B., 1991, Water resources data--California, water year 1990. Volume 1. Southern Great Basin from Mexican border to Mono Lake basin, and Pacific slope basins from Tijuana River to Santa Maria River: U.S. Geological Survey Water-Data Report CA-90-1, 289 p.

Hunter, T.C., Mullen, J.R., and Anderson, S.W., 1991, Water resources data--California, water year 1990. Volume 3. Southern Central Valley basins and The Great Basin from Walker River to Truckee River: U.S. Geological Survey Water-Data Report CA-90-3, 402 p.

Mullen, J.R., Shelton, W.F., Markham, K.L., and Anderson, S.W., 1991, Water resources data--Califormia, water year 1990. Volume 4. Northern Central Valley basins and The Great Basin from Honey Lake basin to Oregon State line: U.S. Geological Survey Water-Data Report CA-90-4, 323 p.

Shelton, W.F., Trujillo, L.F., Markham, K.L., and Palmer, J.R., 1991, Water resources data--California, water year 1990. Volume 2. Pacific slope basins from Arroyo Grande to Oregon State line except Central Valley: U.S. Geological Survey Water-Data Report CA-90-2, 333 p.

Johnson, J.A., Fong-Frydendal, L.J., and Baker, J.B., 1991, Water resources data--California, water year 1990. Volume 5. Ground-water data for California: U.S. Geological Survey Water-Data Report CA-90-5, 387 p. 


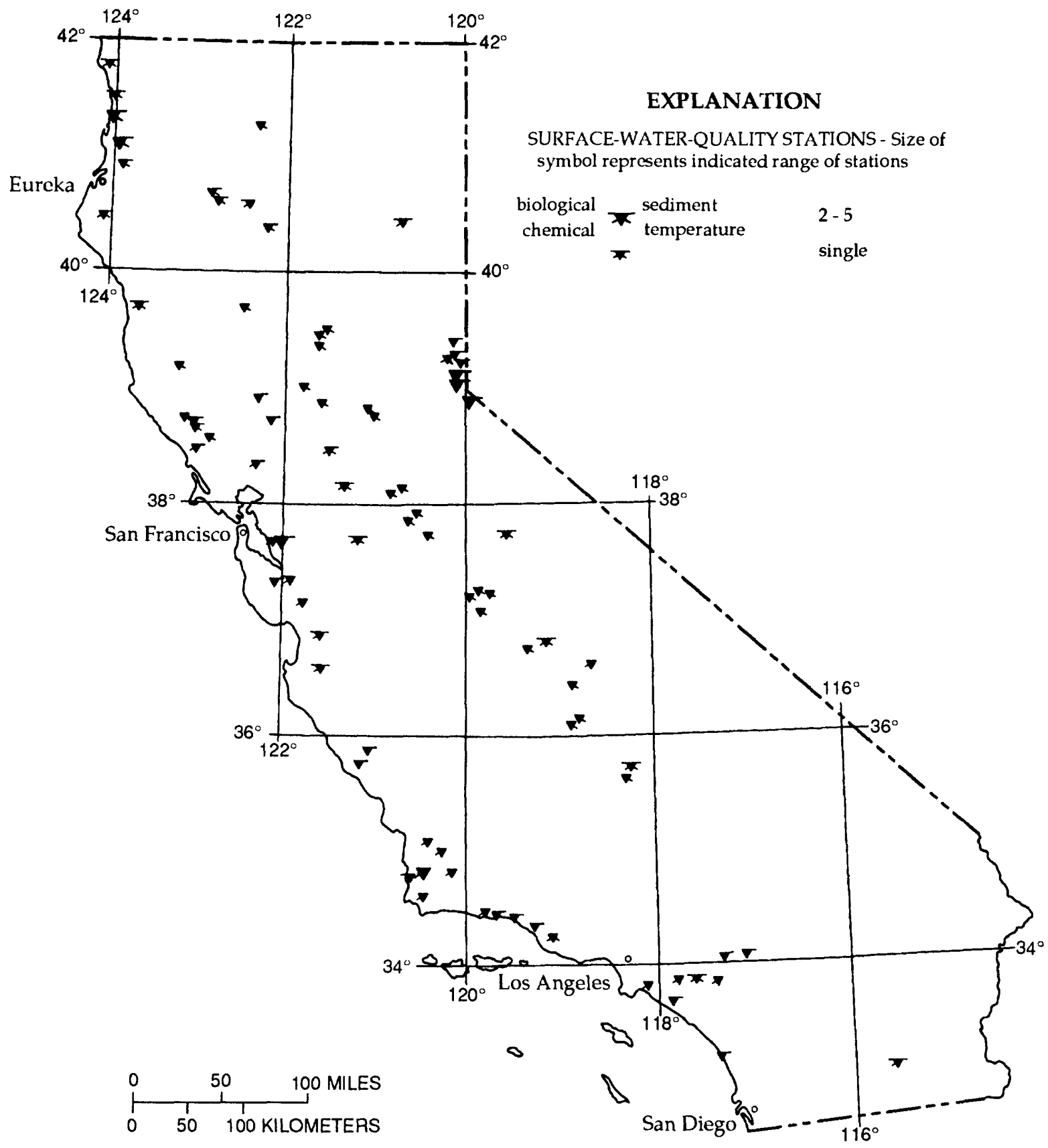

Location of surface-water-quality monitoring stations. 


\section{SEDIMENT STATIONS}

\section{Number: CA004}

Location: Statewide (See accompanying map for water-quality stations, page 19)

Project Chief: James M. Knott

Period of Project: Continuing

Problem: Erosion, transport, and deposition of sediment can have major adverse effects on lakes, streams, and adjacent lands, which may persist for years, decades, or even centuries. Knowledge of sediment transported by streams is essential in the development and management of water and land resources. Large variations in drainage-basin and precipitation characteristics in California result in significant differences in the quantity and composition of fluvial sediment. To obtain knowledge of sediment-transport characteristics of California's wide diversity of streams will require close monitoring of sediment at many locations.

Objectives: The primary objective of the sediment-station monitoring program is to provide data that can be used to aid in the development of land-management practices that will minimize erosion rates. Specific objectives include the evaluation of (1) changes in land- and water-management practices that increase or decrease the supply of sediment to lakes and streams, (2) changes in reservoir capacity due to sediment fluxes, and (3) changes in geomorphology as the result of sediment discharge.

Approach: Suspended-sediment and bed-material samples will be collected at specific sites on streams within the State. Bed-load samples will be collected at those sites that are total-load stations if stream characteristics are suitable. Daily suspended-sediment concentration and discharge will be compiled for daily sediment stations. Monthly bed-load discharge will be estimated for daily total-load stations. Selected sediment samples will be analyzed for particle-size distribution. Standard methods of data collection will be used as described in the series "Techniques of Water-Resources Investigations of the U.S. Geological Survey."

Progress: Sediment data collected during water year 1990 were published in the California annual data-report series. Sediment data collected at 15 daily, 22 periodic, 21 NASQAN (National Stream Quality Accounting Network), and 3 Hydrologic Benchmark stations during water year 1991 are being compiled and reviewed.

Plans for Next Year: Collection of sediment data will continue. Sediment data will be compiled and reviewed and all processed data will be published in the annual data report for water year 1991.

\section{Reports:}

Bowers, J.C., Jensen, R.M., and Hoffman, E.B., 1991, Water resources data--California, water year 1990. Volume 1. Southern Great Basin from Mexican border to Mono Lake basin, and Pacific slope basins from Tijuana River to Santa Maria River: U.S. Geological Survey Water-Data Report CA-90-1, 289 p.

Hunter, T.C., Mullen, J.R., and Anderson, S.W., 1991, Water resources data--California, water year 1990. Volume 3. Southem Central Valley basins and The Great Basin from Walker River to Truckee River: U.S. Geological Survey Water-Data Report CA-90-3, 402 p.

Mullen, J.R., Shelton, W.F., Markham, K.L., and Anderson, S.W., 1991, Water resources data--California, water year 1990. Volume 4. Northern Central Valley basins and The Great Basin from Honey Lake basin to Oregon State line: U.S. Geological Survey Water-Data Report CA-90-4, 323 p.

Shelton, W.F., Trujillo, L.F., Markham, K.L., and Palmer, J.R., 1991, Water resources data--California, water year 1990. Volume 2. Pacific slope basins from Arroyo Grande to Oregon State line except Central Valley: U.S. Geological Survey Water-Data Report CA-90-2, 333 p. 


\section{NATIONAL TRENDS NETWORK FOR MONITORING ATMOSPHERIC DEPOSITION}

Number: CA005

Cooperating Agency: None. (U.S. Geological Survey Federal Program)

Project Chief: Kenneth W. Lee

Period of Project: Continuing

Problem: Fish populations are decreasing because of the increasing acidity of some lakes in the United States due to acidic precipitation. An important question being asked is "What is the areal and temporal variation of the chemical composition of wet-atmospheric deposition in the United States?"

Objectives: Sample and analyze wet-atmospheric deposition and determine the annual deposition rate in areas of California. Sites are part of a national program.

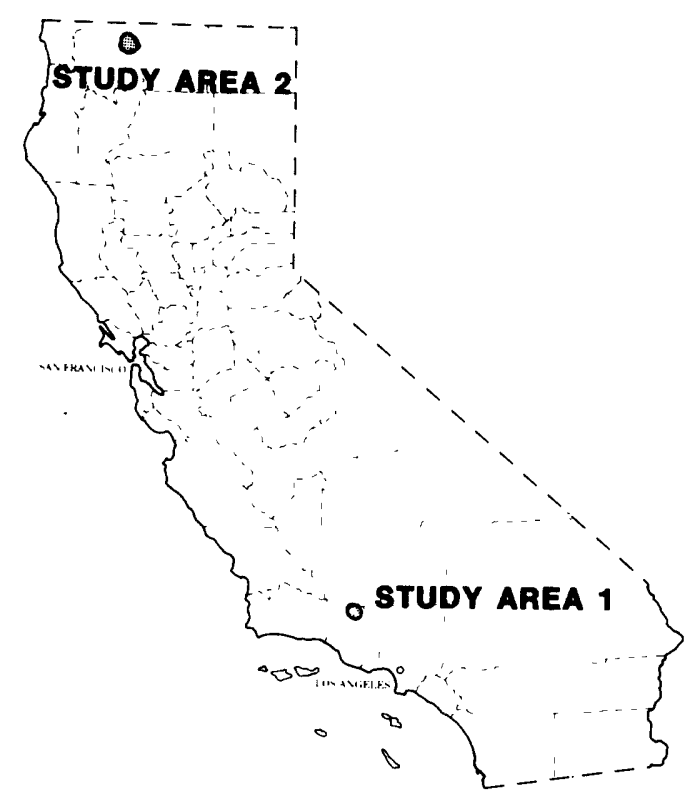

Approach: One atmospheric-deposition sampler will be installed and operated at Chuchupate Ranger Station in Los Padres National Forest in Ventura County (study area 1). Samples will be collected weekly for analysis; thereafter, the data are handled by the National program. The California District will provide quality assurance on sampling techniques for a site near Yreka (study area 2) operated by the Siskiyou County Air Pollution Control District.

Progress: The California District operated one station at Chuchupate Ranger Station, with assistance from the U.S. Forest Service, and provided quality-assurance reviews for one station near Yreka.

Plans for Next Year: Collection and analyses of atmospheric-deposition samples at Chuchupate will continue. Inspections of the Yreka site will continue once or twice annually.

Reports: None. 


\section{WATER-USE INFORMATION FOR CALIFORNIA}

Number: CA007

Cooperating Agency: California Department of Water
Resources

Project Chief: William E. Templin

Period of Project: Continuing

Problem: Nationwide, statewide, and site-specific estimates of water use are needed to establish waterresources policies and to conduct hydrologic investigations; water-use estimates must be consistent in wateruse categories and methods of determination to allow valid comparisons of statewide totals. California continually has the largest water-use volume of any state in the Nation; its multiagency water-management organizational structure and magnitude of water users create a complex water-use information environment. The problem is to meet present and future water-use information needs in the most efficient and cost-effective manner.

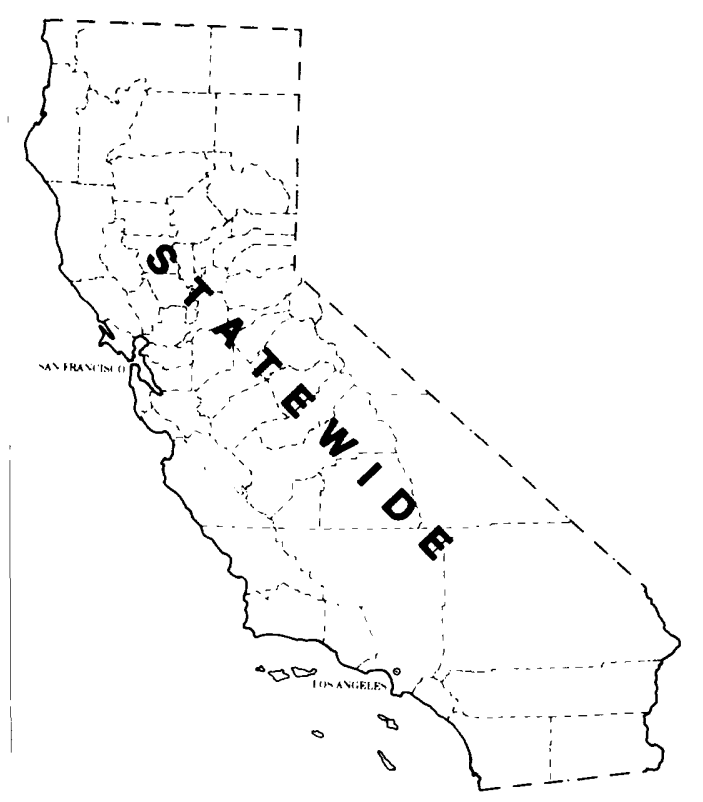

Objectives: (1) Determine how much fresh and saline surface and ground water is withdrawn and for what purposes, how much of this water is consumed during use, and how much water is returned to surface and underground sources after use; (2) maintain and refine computerized systems to store and retrieve statewide and site-specific water-use information; (3) devise and apply new methods and techniques to improve the collection, analysis, and dissemination of water-use information; and (4) explain the values and applications of water-use information, and make this information available.

Approach: Information will be developed for 14 National Water Use categories: irrigation; industrial; commercial; domestic; water supply; sewage treatment; mining; livestock specialties; animal specialties; reservoir evaporation (beginning in 1990); hydroelectric power; and 3 thermoelectric power sources: nuclear, fossil fuel, and geothermal. Site-specific information will be input into a Water Use Data System. Statewide information will be entered into an aggregated Water Use Data System. Methods and techniques for collection, storage, and dissemination of water-use information will be improved.

Progress: The Water-Use Information Program focused on improving coordination with other water agencies in California and on developing estimates of water use in 1990. A statewide water-use coordination work group was formed in cooperation with the Water-Use Section of the California Department of Water Resources to improve the accuracy and agreement of water-use data in California. The California District was involved in developing irrigation and program-planning components for the WaterUse Concepts course at the Denver Training Center and co-chairing the Western Region/Central Region's annual water-use workshop. A revised edition of the National Handbook of Recommended Methods for Data Acquisition, Chapter 11, "Water Use" was developed and submitted to Headquarters for approval. Coordination with subsidence studies in Antelope Valley continued, and a new study started in the South San Francisco Bay area. Progress was made on an open-file report containing water-delivery and crop-use information for the west side of the San Joaquin Valley. The continuing drought added to the number of requests for water-use information that were received from within the Survey and from other agencies.

Plans for Next Year: An open-file report for the west side of the San Joaquin Valley will be published. A report comparing 1985 and 1990 estimates of water use in California will be prepared. In addition, a proceedings article on the use of a forecasting model compared to the use of historical data and standard projection methods in Monterey County will be written and published. A report also will be written on wastewater reuse and water-supply reductions due to conservation in response to drought-created water shortages.

Reports: None. 


\section{GROUND-WATER APPRAISAL, U.S. MARINE CORPS BASE, TWENTYNINE PALMS}

Number: CA027

Cooperating Agency: U.S. Marine Corps, Air Ground Combat Center, Twentynine Palms

Project Chief: Charles A. Kaehler

Period of Project: Continuing

Problem: Most of the water supply for the Twentynine Palms Marine Corps Base is obtained from wells in the Surprise Springs ground-water basin, about 10 miles northwest of headquarters in the Mesquite basin. To use this supply of potable, but distant, water efficiently, the Marine Corps would like to develop alternative sources of ground water for two specific needs: (1) production of about 250 gallons per minute to be used for landscape irrigation at the housing area near the golf course; and (2) production of a minimum of about 100 gallons per minute for a planned facility to wash vehicles. Hydrogeologic information on the Mesquite basin is scarce.

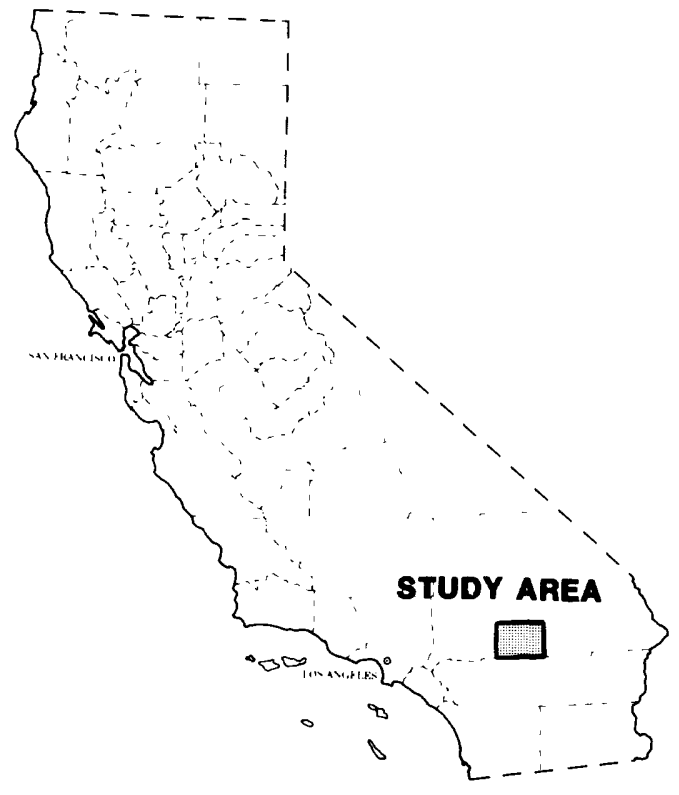

Objectives: Expand on the limited information available on the hydrogeology of the Mesquite basin.

Approach: All available hydrogeologic data for the Mesquite basin will be reviewed, and designs for wells at the two facilities will be formulated. The two sites will be selected on the basis of a hydrologic assessment of the area and on the needs of the Marine Corps. Two wells will be constructed and developed using U.S. Geological Survey drilling equipment. After the wells are constructed and developed, pumping tests will be done to determine well yield and drawdown. Water samples will be collected for analysis of major ions, fluoride, nitrate, boron, and dissolved solids.

Progress: Water-Resources Investigations Report 89-4099 describing the geohydrology and a groundwater flow model of the Surprise Spring basin and Open-File Report 91-482, a supplement to WaterResources Investigations Report 89-4099 were published. Analyses of aquifer tests were completed. Results of aquifer tests done by the U.S. Geological Survey at two new production wells were transmitted to the Marine Corps. Water levels were monitored at 19 wells, and water samples were collected from 4 wells as part of the ground-water monitoring program at the Combat Center.

Plans for Next Year: Monitoring of ground-water levels and chemical quality will continue.

\section{Reports:}

Londquist, C.J., and Martin, Peter, 1991, Geohydrology and ground-water-flow simulation of the Surprise Spring basin aquifer system, San Bemardino County, California: U.S. Geological Survey WaterResources Investigations Report 89-4099, $41 \mathrm{p}$.

Mitten, H.T., and Londquist, C.J., 1991, Documentation of model input and output values for the geohydrology and ground-water-flow simulation of the Surprise Spring basin aquifer system, San Bernardino County, California: U.S. Geological Survey Open-File Report 91-482, 5 p. (Supplement to Water-Resources Investigations Report 89-4099). 


\section{APPRAISAL OF GROUND-WATER RESOURCES, INDIAN WELLS VALLEY}

Number: CA030

Cooperating Agencies: Indian Wells Valley Water District; and U.S. Navy, Naval Weapons Center, China Lake

Project Chief: Roy A. Schroeder

Period of Project: Continuing

Problem: Indian Wells Valley is undergoing rapid population growth and is faced with the problem of managing its water resources in order to best meet future needs.

Objectives: Define current ground-water conditions in the valley using a water-level and water-quality monitoring network and develop a computer model that can be used to predict aquifer response to future

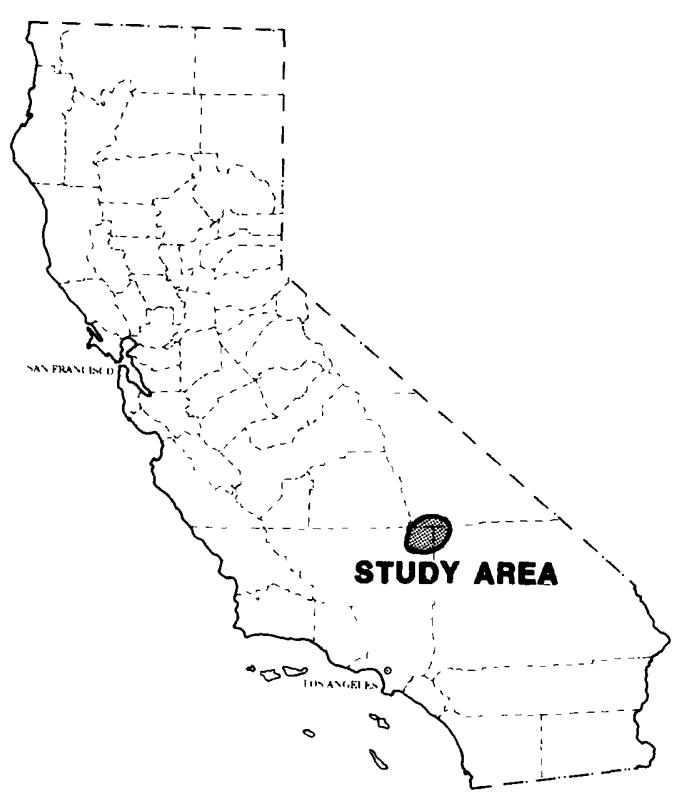
ground-water development.

Approach: Water levels will be measured, ground-water pumpage will be estimated, and samples will be collected for chemical analyses. Previous model data will be reorganized and reevaluated to develop a steady-state and transient-state digital flow model of the basin using the U.S. Geological Survey Modular Model. The flow model will be used to predict ground-water levels primarily in the current pumping centers of the basin under selected management alternatives. Current and historical chemical data will be used to show spatial variations and changes in ground-water quality. The solute-transport model, MODPATH, will be used to illustrate the movement of solutes in response to pumping.

Progress: A report describing the ground-water flow system in Indian Wells Valley was published. A report describing variations in ground-water quality, processes affecting chemical quality, variations in oxygen- and hydrogen-isotope concentrations, and computer simulations of solute transport in Indian Wells Valley was written and has received technical reviews.

Plans for Next Year: The water-quality report will be revised and submitted for Director's approval for publication in the Water-Resources Investigations series. A condensed version will be prepared for publication in a journal if time permits. A network for continued monitoring of ground-water levels and water quality in Indian Wells Valley will be maintained.

Reports:

Berenbrock, Charles, and Martin, Peter, 1991, The ground-water flow system in Indian Wells Valley, Kern, Inyo, and San Bernardino Counties, California: U.S. Geological Survey Water-Resources Investigations Report 89-4191, 81 p. 


\section{CHARACTERIZATION OF THE QUALITY OF WATER RESOURCES OF SANTA CLARA COUNTY}

Number: CA184

Cooperating Agency: Santa Clara Valley Water District

Project Chief: Vacant

Period of Project: Terminated

Problem: The Santa Clara Valley Water District (SCVWD) is concerned with the behavior of contaminants in the reservoirs, streams, and aquifers which serve to store, convey, and treat its water. These contaminants include taste and odor causing algae imported with Central Valley Project water, trace elements in surfacewater runoff from mine tailings, and nitrate in ground water from the application of fertilizers to agricultural lands. The presence of these contaminants in the hydrologic system requires an understanding of the processes that control their mobility and distribution to ensure adequate protection of the water supply.

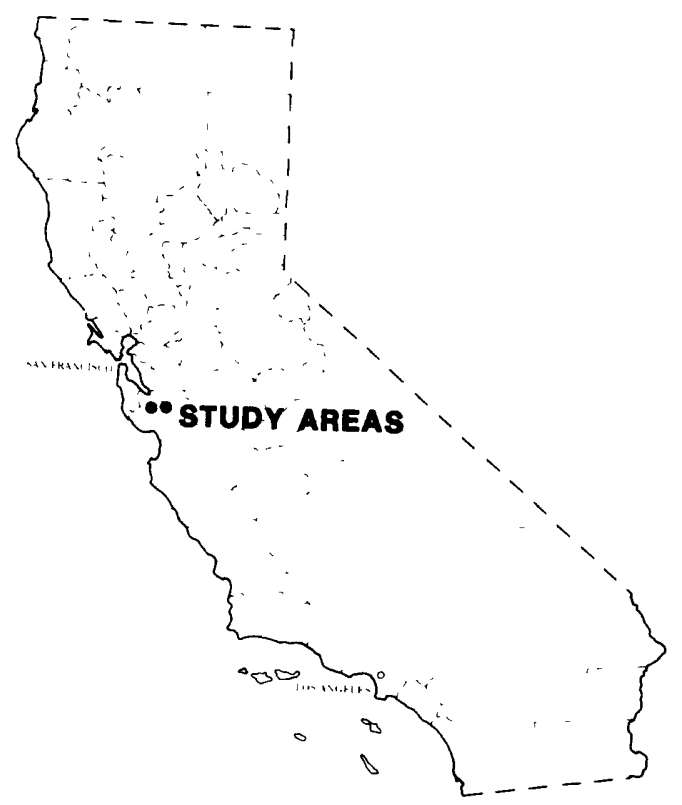

Objectives: General study objectives are to characterize surface- and ground-water quality, assess the processes controlling contaminant transport, and design hydrologic monitoring networks.

Approach: (1) Maintain an optimum surface-water quality monitoring network; (2) determine the processes controlling the mobility of trace elements in the streams, reservoirs, and percolation ponds in the Guadalupe River drainage system; (3) determine the processes controlling the dynamics of the algal blooms responsible for taste and odor problems in Calero Reservoir; and (4) design a ground-water monitoring network for the Llagas-Bolsa subbasins.

Progress: Water-quality data were collected from nine streams at Calero Reservoir. Funding was sufficient only for the collection of water-quality data for the surface-water segment of this study. Samples for major ions and nutrients were collected twice during moderate storms in March 1991. In addition to these constituents, trace elements were determined once during a period of high-flow in March and once during a period of low-flow in July. These data will be used to evaluate water-quality conditions and trace-element distributions in the streams. Calero Reservoir was sampled in April, May, June, August, and September for major ions, nutrients, phytoplankton, and chlorophyll $a$ and $b$ to determine the factors related to algal blooms. No algal blooms were observed during the year; consequently, there were no associated problems with taste and odor. Additionally, trace elements were determined when lake water was nearly anoxic in August 1991. Anoxic conditions produce a reducing environment and may release trace elements bound to bottom sediments. These data may be used to evaluate and manage the surface-water resources of Santa Clara Valley. Work on entering ground-water data into a Geographic Information System (GIS) and development of a conceptual model of the Llagas-Bolsa subbasin was suspended because the ground-water segment of this study was not funded.

Plans for Next Year: Project terminated.

Reports: None. 


\section{CHARACTERISTICS OF FLOODING AND CHANNEL CHANGES OF THE SACRAMENTO RIVER BETWEEN HAMILTON CITY AND BUTTE CITY}

Number: CA271

Cooperating Agency: California Department of Water Resources

Project Chief: Jerry G. Harmon

Period of Project: Continuing

Problem: Flooding in the Sacramento River basin may cause changes in the magnitude and duration of overbank flows to Butte basin and increased amounts of lateral erosion. Continued lateral migration of the channel may cause the Sacramento River to change course and enter Butte basin or allow excessive flows down the main channel of the river, where the design channel capacity decreases in leveed reaches.

Objectives: (1) Define relations and document changes in the proportional division of floodflows between the

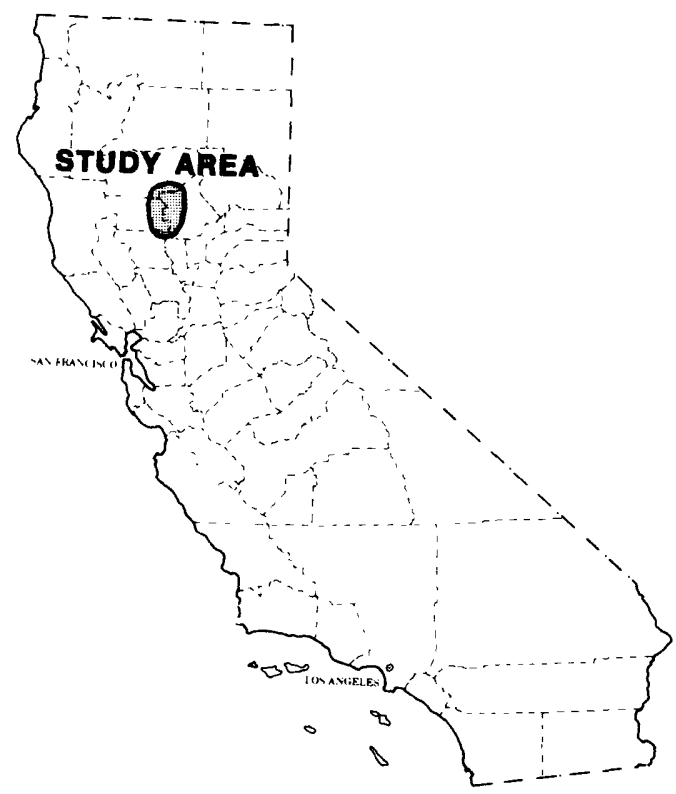
Sacramento River and Butte basin; (2) show the results of channel scour, channel fill, and streambank erosion at monumented cross sections of the river; and (3) present water-surface profiles of floods to provide a base for documenting changes in channel-flow characteristics.

Approach: Flood data (part of the ongoing data-collection program) will be collected. Channel cross-section data at monumented sites will be collected annually. Flood data will include streamflow and surveyed or recorded stage measurements.

Progress: Progress was limited to preparation of reports, annual cross-section surveys, and streamflow-recording gage and crest-stage gage operations until the next flood.

Plans for Next Year: Streamflow-recording gages and crest-stage gages will be in operation during the 1991-92 flood season. The data-collection network will be modified to include peak-stage data near Parrott Weir. Elevations and descriptions of reference marks will be documented to relate to floodflow measurements and surveys of high-water marks along the Sacramento River and in Butte basin. Flows will be measured and recorded to document changes or stability in characteristics of floodflows. Monumented cross sections of the river will be resurveyed annually and compared with data from previous surveys for each of the seven sites. A report will be written after the next flood to document changes in floodflow characteristics following an extended drought period.

Reports: None. 


\title{
GROUND-WATER RESOURCES OF THE SANTA BARBARA AREA
}

Number: CA342

\author{
Cooperating Agency: Santa Barbara, City of \\ Project Chief: John R. Freckleton
}

Period of Project: July 1977 to September 1992

Problem: The reduced efficiency of surface reservoirs due to siltation will place increasing pressure on the ground-water supply in the Santa Barbara ground-water basin. Because of anticipated pumpage in the basin and the possibility of seawater intrusion into the freshwater aquifer, it has become necessary to develop and implement a ground-water program capable of evaluating the effects of anticipated stresses on the ground-water basin.

Objectives: Design a comprehensive program to regularly monitor water levels and water quality in the ground-water basin in order to measure the effects of increased pumping and the potential movement of seawater into the ground-water reservoir. Results of the monitoring program will be used to develop a computer model of the Santa Barbara area ground-water basin that will aid in defining the hydrogeology of the basin and aid in the management of local water resources.

Approach: Previous investigations will be reviewed. Historical water-level and water-quality data and rainfall and streamflow records will be collected and analyzed. Additional hydraulic data, such as storage coefficient and transmissivity estimates, will be collected. A finite-difference flow model based on measured or estimated hydraulic properties and known or estimated values of recharge and discharge will be developed. The mathematical model will be used to investigate various pumping alternatives that may lessen the effects of increased pumping in the study area.

Progress: Eight new wells were completed in June 1991 in the Santa Barbara area ground-water basin. One borehole containing two wells was drilled in Storage Unit I. Two boreholes with two wells each and two boreholes with one well each were drilled in Storage Unit III. The new wells will be used to monitor the effects of pumping on water levels near the Mesa fault, which may be a barrier to ground-water flow. Examination of the driller's logs and analysis of the drill cuttings indicate that water-bearing deposits do not extend as far southeast in Storage Unit III as originally was believed because the Sespe Formation was encountered at shallow depth. The Sespe Formation is a reddish-brown shale characterized by poor water quality and low water yield. Slug tests were done on three sets of nested wells in Storage Unit III to estimate storage coefficients and transmissivities of both water-bearing deposits and the Sespe Formation. An addition to the USGS Modular Manual, called the Horizontal Flow-Barrier Package, was used to simulate fault boundaries in the areawide model (Storage I and III and the Foothill basin). Several sections of the horizontal-flow barrier documentation report have been written and the main body of the report was revised and the logic of the Fortran source code was verificd. The Horizontal-Flow Barrier Package was tested using the combined Santa Barbara basin flow model.

Plans for Next Year: A report describing the geohydrology of Storage Unit III will be completed. Development of a combined-flow model of the Santa Barbara ground-water basin will continue, and the report documenting the Horizontal-Flow Barrier Package will be prepared.

\section{Reports:}

McFadden, M.C., Polinoski, K.G., and Martin, Peter, 1991, Measurement of streamflow gains and losses on Mission Creek at Santa Barbara, California, July and September 1987: U.S. Geological Survey Water-Resources Investigations Report 91-4002, 15 p. 


\section{ESTIMATING TIDAL AND RESIDUAL CIRCULATION IN SAN FRANCISCO BAY}

Number: CA419

Cooperating Agency: California Department of Water Resources; and California State Water Resources Control Board

Project Chief: Lawrence H. Smith

Period of Project: Continuing

Problem: California State and Federal water projects regulate the quantity of fresh water flowing into San Francisco Bay from the Sacramento-San Joaquin River Delta. This regulation has caused a decrease in the annual inflow of fresh water to the bay and has altered the time sequences of inflows during the year. The effect of decreased inflow may be altering the mixing characteristics of the bay and adversely affecting fish and shrimp populations.

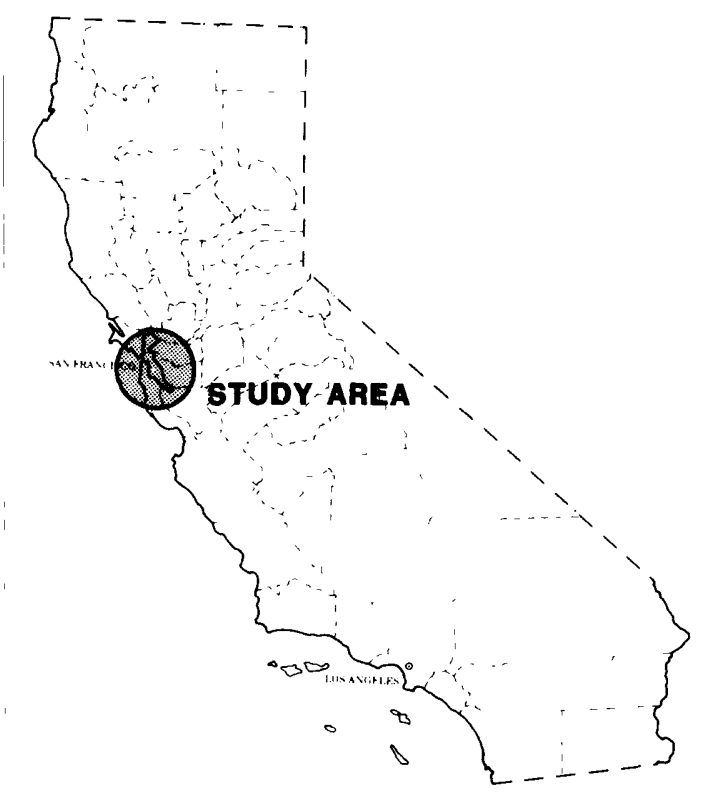

Objectives: To determine the magnitude and location of variations in hydrodynamics (water currents and salinity) within San Francisco Bay that result from changes in freshwater inflows from the Sacramento-San Joaquin River Delta.

Approach: Two- and three-dimensional mathematical models will be used to project the effect of variations in delta flows on water currents and salinity in the bay. In addition, currents and salinity will be measured during a wide range of delta-flow conditions. A new prototype of a vessel-mounted acoustic Doppler current profiling (ADCP) system will be tested and used to measure vertical profiles of currents. A high resolution in situ conductivity-temperature-depth system will be used to measure vertical salinity profiles. Field data will be used as appropriate to calibrate and validate mathematical models.

Progress: Two monitoring stations for water levels, one station for salinity, and two stations for meteorological data were operated in northern San Francisco Bay. Data from these stations, along with several years of historical salinity data from six additional monitoring stations, were reviewed and entered into a computerized hydrodynamic data base. Analyses of the monitoring data were continued in order to study the causes of low-frequency variations in water levels and salinities. A three-dimensional model was used in San Pablo Bay to simulate the vertical and lateral distributions of residual currents for six cross sections of the bay. The simulations showed that residual currents are sensitive to freshwater inflow and tidal currents interacting with the complex bay bathymetry and that there is a pronounced variation in gravitational circulation during the spring-neap cycle. Finally, Director's approval was received for a water-supply paper describing an acoustic Doppler, moving-boat discharge-measurement system.

Plans for Next Year: Analyses of monitoring station data and the three-dimensional modeling of San Pablo Bay will continue. Coding of a new three-dimensional model for all of San Francisco Bay will begin. If funding becomes available, four UVMs (ultrasonic velocity meters) will be installed at delta sites and calibrated. The flow data will be used to validate a new delta flow model and to measure delta transfer and delta outflow. A prototype of a new broad-band ADCP will be tested.

\section{Reports:}

Smith, P.E., Cheng, R.T., Burau, J.R., and Simpson, M.R., 1991, Gravitational circulation in a tidal strait: American Society of Civil Engineers, National Conference on Hydraulic Engineering, Nashville, Tennessee, July 29-August 2, Proceedings, p. 429-434. 


\section{SOUTHERN CALIFORNIA REGIONAL AQUIFER-SYSTEM ANALYSIS}

Number: CA424

\author{
Cooperating Agency: None. (U.S. Geological Survey \\ Federal Program)
}

\section{Project Chief: Peter Martin}
Period of Project: October 1990 to September 1993 (reactivated)

Problem: To meet the needs for hydrologic information on a regional scale and to develop predictive capabilities to effectively manage the Nation's ground-water resources, the U.S. Geological Survey has initiated a series of hydrologic investigations in the Regional Aquifer Systems Analysis (RASA) program. The RASA study of the southern California basins covers a 75,000 -square-mile area. The area includes 89 drainage basins that can be grouped into coastal and desert basins according to common characteristics and relations.

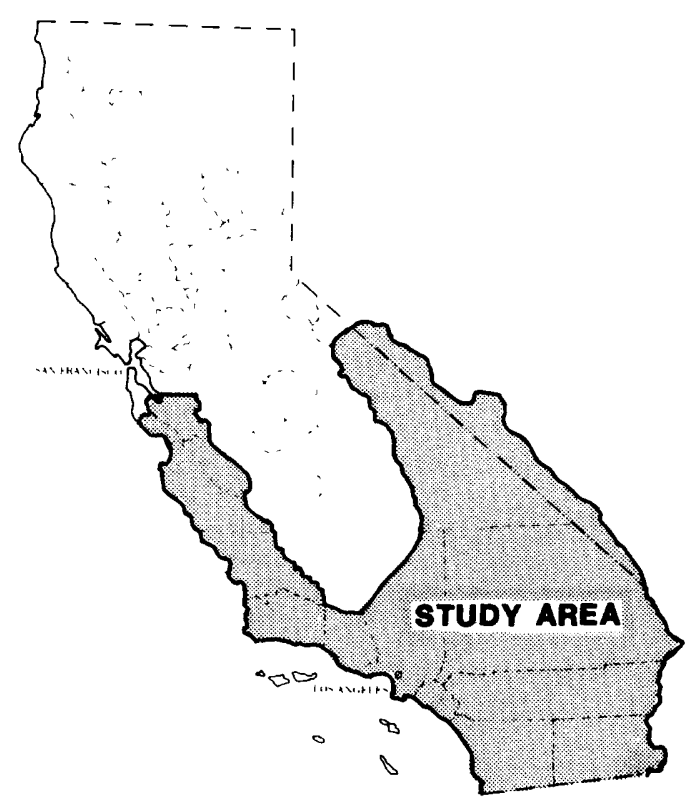

Objectives: The objective of the study is to analyze the major problems and issues that affect the use of ground water in southem California including: (1) ground-water overdraft, (2) ground-water contamination, (3) seawater intrusion, (4) quantity and distribution of recharge, (5) inter-aquifer flow, and (6) conjunctive use of ground water and surface water. Because of the large size of the study area and the large number of basins involved, it is impractical to study these problems and issues for each basin. Therefore, at least one coastal basin and one desert basin will be selected for intensive study to determine the major geohydrologic processes and human activities that control or influence these problems and issues.

Approach: The Santa Clara-Calleguas coastal basin and the Mojave Desert basin were selected for this study. These basins are affected by all the major problems and issues identified for study. The first phase of these intensive studies will involve assembling available geohydrologic data into a geographic information system (GIS), defining the regional geohydrology and geochemistry, and developing ground-water flow and solute-transport models to help understand the ground-water flow system. Information obtained from these intensive studies will aid in the effective management of the ground-water resources of these and other basins in southern California. The second phase of the study will include data collection and modeling where necessary to better gain knowledge and to report on the (1) geohydrologic framework; (2) geochemistry and water-quality problems; (3) hydraulics of seawater intrusion; and (4) ground-water use including hydraulic and economic optimization of management alternatives. The second phase of the study will include data collection and modeling where necessary to better gain knowledge and to report on the (1) geohydrologic framework; (2) geochemistry and water-quality problems; (3) hydraulics of seawater intrusion; and (4) ground-water use including hydraulic and economic optimization of management alternatives.

Progress: During the past year, almost the entire effort of the RASA study has involved assembling and analyzing geohydrologic and geochemical information for the Santa Clara-Calleguas basin. This effort has included developing a computerized GIS, describing the geohydrology of the basin on the basis of well logs, evaluating the geochemistry of the basin using new and historical data, and developing the regional ground-water-flow model. To describe the geohydrology of the basin, more than 200 electric logs of oil and deep-water wells have been digitized and processed for graphical representation. Correlation of these logs currently is being done to define the different aquifers and the geologic structure of the basin. The 
geochemistry of the basin has been evaluated by analyzing existing data compiled on the GIS and collecting more than 150 samples as part of this study.

One of the main objectives of the RASA study is to determine how geohydrology and human activities affect seawater intrusion. Therefore, much of the effort has been concentrated on collecting samples near the coastal section of the study area. On the basis of previous studies, it had been estimated that more than 23 square miles of the Oxnard aquifer (shallowest of the five major aquifers) is intruded by seawater that entered primarily through outcrop areas in submarine canyons near the coast. Waterquality data, including stable-isotope analyses, from more than 40 wells installed as part of this study show that the area affected by seawater intrusion is less than originally believed. The source of elevated chloride concentration, in at least some wells, is leakage of seawater through failed well casings or through abandoned irrigation wells perforated in more than one aquifer. In other wells, irrigation return may be the cause of elevated chloride concentrations. In addition, seawater has intruded deeper aquifers near Hueneme submarine canyon and a brine other than seawater may have invaded deeper aquifers near Point Mugu.

Plans for Next Year: During fiscal year 1992 the GIS data bases for the Santa Clara-Colleguas basin will be completed and fully operational. Geochemical data will be collected to further define the source and age of water in the different aquifers. The regional ground-water-flow model will be developed and calibrated. Interpretive reports describing the coastal basin results will be prepared. In addition to completing work in the Santa Clara-Calleguas basin, assembling and analyzing geohydrologic and geochemical information for the Mojave basin will begin.

\section{Reports:}

Izbicki, J.A., 1991, Chloride sources in a California coastal aquifer: American Society of Civil Engineers, Irrigation and Drainage Division Conference on Ground Water in the Pacific Rim Countries, Honolulu, Hawaii, July 23-25, Proceedings, p. 71-77. 


\title{
HYDROLOGIC STUDIES RELATED TO VOLCANIC ACTIVITY IN LONG VALLEY
}

\author{
Number: CA431
}

Cooperating Agency: None. (U.S. Geological Survey Federal Program)

\section{Project Chief: Christopher D. Farrar}

\section{Period of Project: Continuing}

Problem: Long Valley along the eastern Sierra Nevada frontal fault is part of a large volcanic depression called the Long Valley caldera. Since 1978, earthquake activity has increased in the caldera. This earthquake activity and a total uplift of 31 centimeters probably are a result of rising magma. On May 26, 1982, the U.S. Geological Survey issued a notice of potential volcanic hazard in the Long Valley area. In response to this notice, the Survey has taken the lead in studies that include monitoring, assessment of potential hazards, and research for methods of prediction.

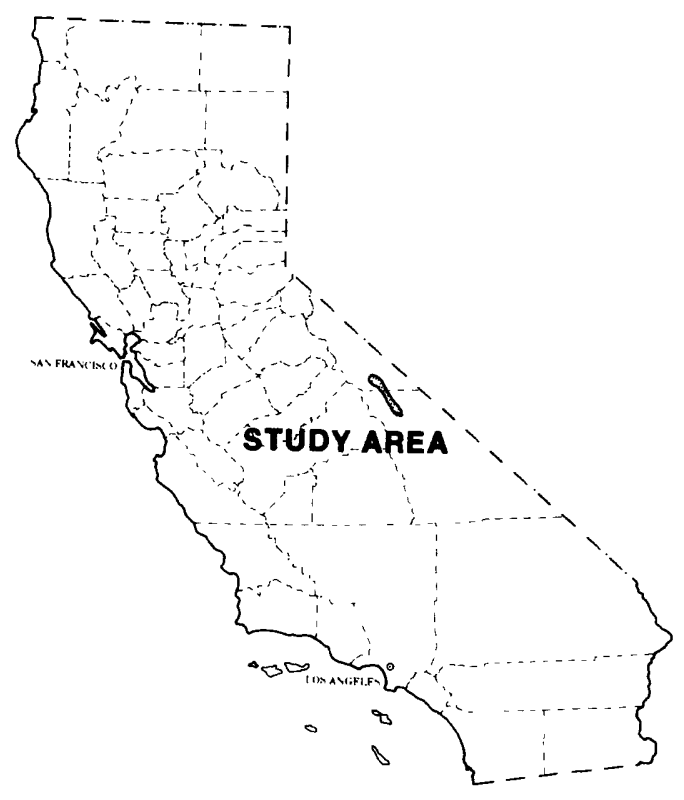

Objectives: The project is divided into three phases with the following objectives: Phase 1--monitor ground water and surface water to detect changes in the hydrologic system caused by geologic processes and phenomena associated with volcanism or with magma at depth in Long Valley caldera. Phase 2--determine the flood discharge at selected locations, depth of flow, extent of inundation, and time of travel of flood wave following projected failure of Long Valley Dam (Lake Crowley) on Owens River. Phase 3--delineate type and magnitude of changes that would be expected in the ground-water system of Long Valley caldera prior to volcanic eruption.

Approach: Phase 1--operate a network to monitor ground-water levels, water temperature and water quality, and surface-water quality. Relate data to geologic events. Phase 2--apply General Purpose Dam-Break Flood Simulation Model (K-634) for a projected dam failure. Application of other models or development of a new diffusion model will be considered. Phase 3--develop quantitative models capable of analyzing the interactions that take place between water-saturated rock and magmatic intrusions.

Progress: Data were collected from a monitoring network that included ground-water levels, discharge rates of springs and streams, ground-water and fumarole temperatures, chemical and stable-isotope analyses of water samples, and analyses of gases from fumaroles (Mono County provided funds to collect data from stream-sites, springs, and wells in the Mammoth Creek drainage.) Monitoring-network data show that the hydrologic system was most notably affected by 5 years of below average precipitation that has caused diminished discharges from streams and springs, lower ground-water levels, and increased temperatures in some springs and streams. Increased pumpage also has lowered ground-water levels as much as 40 feet locally. The hydrothermal system has shown responses to increased geothermal pumpage which has increased the rate of steam discharge from fumaroles around the Casa Diablo well field and dried-up a boiling spring located 1 mile away. Changes in thermal spring locations in Hot Creek gorge are associated with three periods of seismic swarm activity; however, the total flow of thermal water has remained relatively constant at about 240 liters per second. The temperature and helium $3 / 4$ ratio of gas discharged from a fumarole on Mammoth Mountain have declined in response to diminished seismicity under the mountain. Aerial infrared surveys were made for Mammoth Mountain and the Casa Diablo area to identify thermal anomalies. Leveling surveys were made in and around the Casa Diablo well field to detect subsidence possibly caused by thermal contraction of geothermal reservoir rocks. 
Plans for Next Year: Data collection from a monitoring network of 12 recording sites will continue through 1992. Ground-water-level fluctuations will be interpreted in terms of aerial strain in the aquifer. Leveling surveys will be used to detect subsidence in the geothermal field and to compare strain detected from ground-water-level fluctuations. Repeat aerial infrared surveys will be compared with 1991 surveys to detect changes in thermal discharge from Mammoth Mountain and Casa Diablo.

\section{Reports:}

Farrar, C.D., 1991, Hydrogeology of the interstratified volcanic rocks and glacial deposits in Mammoth basin, Mono County, California: Geological Society of America, Abstracts with program, v. 23, no. 5 , p. 215.

Farrar, C.D., and Lyster, D.L., 1991, Hydrologic monitoring for effects of geothermal and ground-water development, Long Valley caldera, California, in Symposium on Subsurface Injection of Geothermal Fluids, Santa Rosa, California, October 29-30, 1990, Proceedings: Oklahoma City, Oklahoma, Underground Injection Practices Council, p. 157-171. 


\title{
INVESTIGATION OF LAND SUBSIDENCE, SACRAMENTO VALLEY; APPLICATION OF A NEW TECHNIQUE FOR INVESTIGATION OF LAND SUBSIDENCE
}

\author{
Number: CA459
} Cooperating Agency: California Department of Water
Resources

Project Chief: Marti E. Ikehara

\section{Period of Project: October 1985 to September 1991}

Problem: Land subsidence of more than 4 feet since 1960 has been estimated in parts of the Sacramento Valley as a result of increased ground-water pumping. The effectiveness of many floodways, levees, and drains has been impaired by this subsidence. In the Sacramento Valley, many benchmarks used to measure subsidence have questionable elevations. In addition, the aquifer mechanics responsible for land subsidence in the Sacramento Valley have not been studied.

Objectives: The primary objective is to document

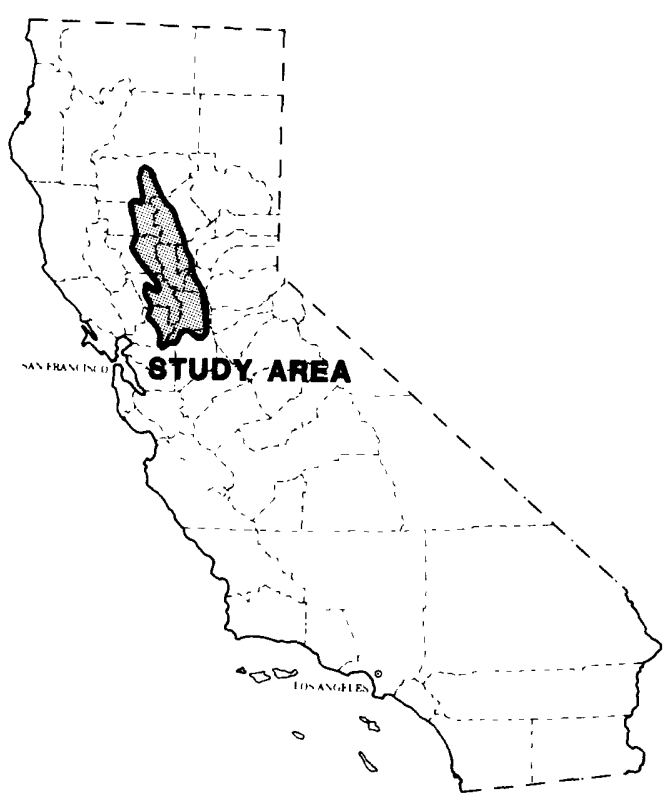
existing land subsidence and describe the aquifer mechanics involved in subsidence. Specific objectives include (1) evaluation and application of a new surveying procedure called Global Positioning System (GPS), which provides a rapid and relatively inexpensive method of repeat leveling and (2) establish a monitoring program to detect any continuing subsidence.

Approach: A pilot study was done to evaluate the GPS survey capabilities. GPS surveying was considered suitable and thus was used to survey a primary network of stable benchmarks and a secondary network in areas of krown and possible subsidence. A field inventory of unused or abandoned wells that are suitable for extensometer, piezometer, and possibly strain meter installation was done in areas of suspected subsidence. If suitable existing wells were not located, new wells were drilled. These wells are used to monitor the overall magnitude and rate of subsidence at each site.

Progress: A paper, "Repeat Global Positioning System Surveying to Monitor Land Subsidence in Sacramento Valley, California" was written for presentation at the Fourth International Symposium on Land Subsidence in May 1991. Results of the first GPS survey indicated that the benchmarks selected as control points in that survey were not sufficiently stable. Thus, another control network was designed and used in the next survey in 1989, but comparisons from the two GPS surveys cannot be made for subsidence monitoring purposes because different control points were used. Sediment cores collected from various sites in Sacramento Valley were examined at a Geologic Division soils laboratory in Golden, Colorado, and the best subsamples were selected for testing. Samples that were not good candidates for consolidation and permeability tests were identified and scheduled for triaxial consolidation testing instead. The transect where the extensometer and piezometers are located was re-leveled and showed the same magnitude and rate of subsidence as those measured for the past few years.

Digital data collected at the subsidence monitoring station near Woodland are being processed. These data will be published in an open-file data report.

Plans for Next Year: An article is being prepared for the International Association of Hydrological Sciences. Ground-water levels, sediment compaction, and atmospheric pressure data at the subsidence monitoring station near Woodland will continue to be processed for publication in an open-file data report. 
Leveling and GPS surveying data also will be processed for publication in an open-file data report. Elevation determinations and land subsidence calculations, and data from a subsidence monitoring station and sediment cores will be analyzed for publication in a water-resources investigations report.

\section{Reports:}

Ikehara, M.E., 1991, Land subsidence in the Sacramento-San Joaquin Delta, California: U.S. Geological Survey Open-File Report 91-452, 2 p. (Water Fact Sheet)

1991, Repeat of GPS surveying to monitor land subsidence in Sacramento Valley, California: Eos, Transactions of the American Geophysical Union, Abstracts, v. 72, no. 44, p. 118. 


\section{EVALUATION OF GROUND-WATER CONTAMINATION FROM NONPOINT SOURCES USING SOLUTE-TRANSPORT TECHNIQUES}

\author{
Number: CA466 \\ Cooperating Agency: Santa Ynez River Water \\ Conservation District
}

Project Chief: Daniel J. Bright

\section{Period of Project: Continuing}

Problem: Several studies have documented the deterioration of ground-water quality in the Lompoc area of the Santa Ynez River basin. These studies indicate that recharge of irrigation water probably is the principal cause of the observed deterioration. Ground water in the Lompoc area, especially in the Lompoc plain, is only marginally acceptable for most uses. Dissolved-solids concentrations currently exceed 2,000 milligrams per liter in several parts of the plain. If the ground-water quality continues to deteriorate, the ground water will be unusable for almost all uses without some treatment.

Objectives: Define the geohydrologic framework of the Lompoc area of the Santa Ynez River basin. Define quantitatively, where possible, the effects of irrigation on the quality of ground water. Evaluate ground-water flow and solute transport using numerical simulation.

Approach: Existing hydrologic data will be used to define the geohydrologic and geochemical framework of the study area. Observation wells and suction-cup lysimeters will be installed on four study plots that are typical of agricultural and geohydrologic conditions in the areas. Water levels will be monitored monthly, and wells will be sampled bimonthly. A three-dimensional finite-difference ground-water-flow model will be developed to simulate flow through the unconsolidated deposits that fill the basin. The movement of solutes in the main water-producing zone will be simulated using a two-dimensional, finite-element solute-transport model.

Progress: The report on phase 1 of this study, evaluating geohydrology and water-quality conditions of the Lompoc area, received Director's approval. In phase 2 of the study, sensitivity analyses for the ground-water flow and solute-transport models indicate that simulated hydraulic head and dissolved-solids concentrations for the main water-producing zone were most sensitive to changes in model input of total annual recharge and pumpage, and dissolved-solids concentrations for the overlying middle zone, respectively. Model simulation of selected ground-water management alternatives was done. The managementalternatives simulations for the 32-year period 1989-2020 include (1) doubling the average annual recharge from the Santa Ynez River, (2) simulating the effect of importing supplemental water, (3) changing the current location of the wastewater-treatment plant discharge point, and (4) reducing the average annual agricultural pumpage by 50 percent. Model results indicate that projected dissolved-solids concentration for the main water-producing zone would decrease beneath the eastern and central plains in all management alternatives. Beneath the western plain, however, projected dissolved-solids concentration decreased only in simulation 4 , in which agricultural pumpage is reduced. A preliminary report describing the results of the ground-water flow and solute-transport models was written.

Plans for Next Year: The report will be reviewed and submitted for approval. Collection of data will continue.

\section{Reports:}

Bright, D.J., Stamos, C.L., Martin, Peter, and Nash, D.B.. 1992, Ground-water hydrology and quality in the Lompoc area, Santa Barbara County, California, 1987-88: U.S. Geological Survey WaterResources Investigations Report 91-4172, 77 p. 


\section{OPTIMUM MANAGEMENT IN A BASIN WITH CHANGING WATER-SUPPLY AND WATER-QUALITY PROBLEMS}

Number: CA467

Cooperating Agency: San Bernardino Valley Municipal Water District

Project Chief: Wesley R. Danskin

Period of Project: October 1987 to September 1993

Problem: Historically, water purveyors have applied various techniques to solve their water-supply and waterquality problems. Although most water purveyors rely on some form of conjunctive use of ground and surface waters, seldom is there optimum management of the entire water system. Improved management of complex hydrologic systems should be possible by developing and applying hydraulic- and economic-optimization techniques. But, to date, the actual use of optimization techniques to solve real-world water-supply and water-quality problems has been slight.

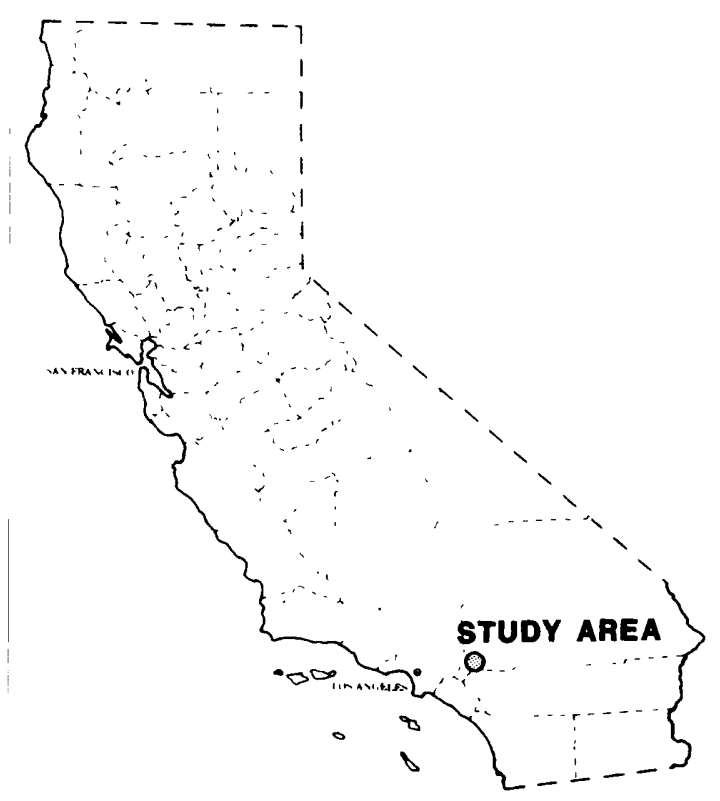

Objectives: Develop and apply optimization techniques to demonstrate their usefulness in a real-world setting for conjunctive management of ground-water pumpage, ground-water levels, quality of ground water, and artificial recharge of surface water. Research will focus on developing new methodologies to incorporate system and parameter uncertainty in the optimization model.

Approach: Key aspects of the ground-water system will be verified to ensure accurate simulation with the existing ground-water-flow model. A surface-water distribution model will be designed and constructed. Critical water-quality problems and potential management options will be identified. A hydraulic/ economic-optimization model will be developed that combines the surface- and ground-water models with the water-quality issues. New methods of water management will be evaluated.

Progress: The optimal water-management study of the San Bernardino area successfully demonstrated the application of constrained optimization techniques in a complex, real-world setting. A linked surfaceand ground-water model was developed and calibrated for the period 1945-89 in order to provide quantitative information about the response of the ground-water system to alternate methods of water management. Information from this model was combined with water-quality and economic information to form a constrained optimization model, which was used to identify optimal mathematical solutions to various water-management questions. The primary questions that were investigated involved tradeoffs between recharge, pumpage, and the rate of movement of organic contaminants through the ground-water system. In particular, the constrained optimization model was used to identify the optimal quantity and location of: (1) recharge necessary to maintain ground-water levels in alluvial fan areas; (2) pumpage necessary to dewater the downtown area, which is susceptible to liquefaction in the event of a major earthquake; (3) pumpage necessary to control two areas of trichloroethylene (TCE) contamination; and (4) combined recharge and pumpage required at two planned water-supply facilities. 
Plans for Next Year: The present study has been extended to address the critical aspect of monitoring in the basin and to aid in implementing results of the optimization study. Key water-management control points will be selected to monitor water-level and water-quality changes throughout the basin. These control points, identified using the ground-water-flow and optimization models, will serve as surrogates for the complex models and largely replace the need for frequent simulations. Reports documenting the models and summarizing results of the optimization study will be completed.

\section{Reports:}

Danskin, W.R., 1991, Advice and arbitration: The role of numerical models in the public sector (abs.): Geological Society of America, Cordilleran Section Annual Meeting, San Francisco, March 25-27, 1991, Program.

Danskin, W.R., Farrar, C.D., and Dreiss, S.J., 1991, Ground-water basins along the eastern Sierra Nevada: Tectonics, water, and politics, in Walawender, M.J., and Hanan, B.B., eds, Geological excursions in southern California and Mexico: Geological Society of America, Annual Meeting, San Diego, California, 1991 Guidebook, p. 447-473. 


\section{RAINFALL AND RUNOFF IN THE ANTELOPE VALLEY DRAINAGE AREA}

Number: CA469

Cooperating Agency: Los Angeles County Department of Public Works

Project Chief: James C. Blodgett

Period of Project: October 1987 to September 1992

Problem: Storm runoff in drainage basins being urbanized in Antelope Valley, California, is a major concern because increases in effective impervious areas in new developments cause increases in storm runoff volumes and peak magnitude. Reliable methods to estimate regional storm runoff are needed for land-use planning, establishing land-development criteria, and designing drainage facilities. Because numerous rainfall-runoff models are available, local development regulatory agencies are confronted with the problem of selecting the correct model for their region.

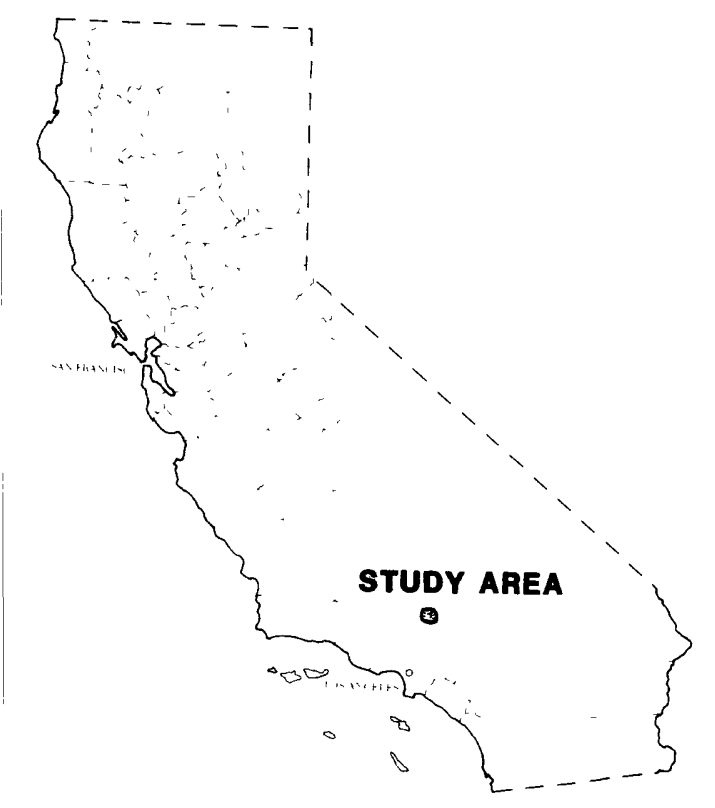

Objectives: The primary objectives are to (1) derive runoff frequencies for long-term simulation and (2) select a rainfall-runoff model appropriate for estimating design storm characteristics in ungaged drainage basins in Antelope Valley. Specific objectives include (1) instrumentation and measurement of rainfall and runoff in nine drainage basins in Antelope Valley and (2) testing and comparison of various rainfall-runoff models to simulate measured runoff.

Approach: Nine basins that represent urbanized and nonurbanized conditions will be selected for collection of continuous-flow and precipitation data. Using this data and suitable historical data, various rainfall-runoff models will be calibrated and results evaluated. Basins will be selected to provide four types of hydrologic data: flood magnitude and frequency and precipitation-runoff model calibration; flow duration and frequency; and flow attenuation in a downstream direction. Aerial photography and infiltration measurements will be obtained to evaluate characteristics of the basins and flow for model application.

Progress: Streamflow and precipitation data for the 1991 water year are being processed; only one storm occurred (March 1991) during the year. Efforts to assemble and analyze historical rainfall data for all long-term precipitation stations in order to provide rainfall frequency and areal distribution data in Antelope Valley continued. Precipitation data also were collected at each streamflow station. Infiltration measurements using a DC infiltrometer were obtained for all nine study basins. The DR3M computer model was used to evaluate various rainfall and runoff parameters so that special emphasis on collecting or assembling these data can be made. The PRIMS model was not applied because of a lack of data. An evaluation of historical rainfall-runoff data will be used to identify significant basin and precipitation characteristics as part of a regional analysis for Antelope Valley. One result of the first application of the DR3M model using the urbanized basins was to establish a need for checking the actual basin area that contributes flow at the gage. Basin boundaries are extremely difficult to determine from aerial photographs. Topographic maps are obsolete because of radical basin grading prior to home construction, and construction plans are unreliable. 
Plans for Next Year: Rainfall-runoff data will be collected on a continuing basis and processed using a format suitable for modeling. Newly collected data will be applied to the rainfall-runoff model. The model will be calibrated and compared with other selected models. The rainfall-runoff model will be extended to include historical data for selected streamflow stations in order to better define the frequency of rainfall and corresponding runoff. Because of the drought, the project will be extended at least one more year. The quality assurance group will prepare a new regional flood-frequency relation applicable to Antelope Valley.

Reports: None. 


\section{DETAILED STUDY AND ASSESSMENT OF IRRIGATION DRAINAGE IN THE SALTON SEA AREA, IMPERIAL VALLEY}

Number: CA470

Cooperating Agency: U.S. Department of the Interior

Project Chief: Roy A. Schroeder

Period of Project: October 1987 to September 1992

Problem: A reconnaissance study during 1986-88 found high selenium concentrations in irrigation drainage and biota from the Salton Sea area. Selenium and other potential toxins in agricultural drainage are a source of concern for aquatic wildlife throughout the Imperial Valley, which has resulted in restrictions on the human consumption of fish from the Salton Sea.

Objectives: Determine the source, transport, and fate of selenium and other potential toxins in the Imperial Valley.

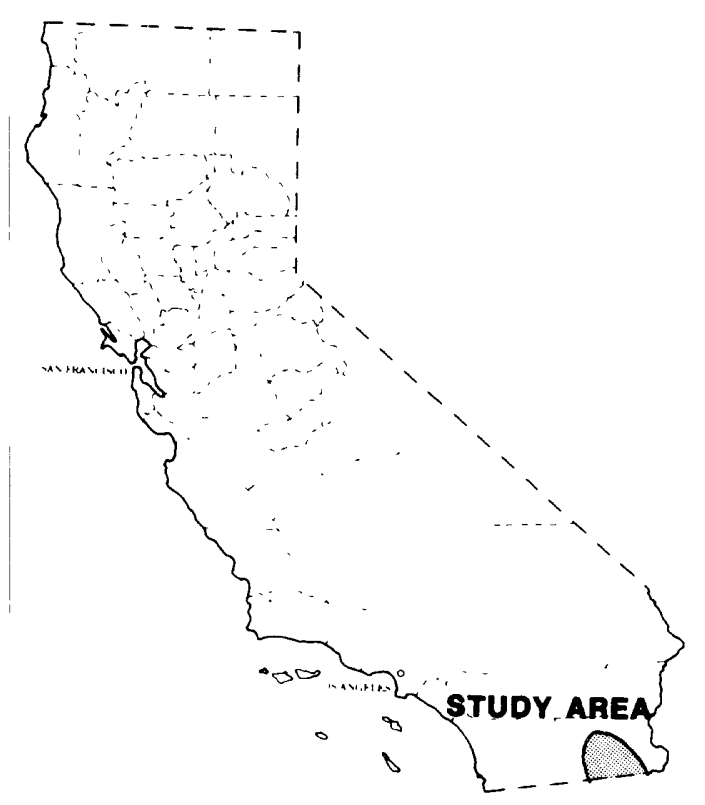

Approach: About 100 field sumps will be sampled for comparison with drainwater quality in 1986 . Results will be used to prepare concentration maps and to establish relative importance of various hydrogeochemical processes. Twenty-one sites are monitored monthly to determine temporal variability. Lysimeters and piezometers will yield information on interaction between drainwater and regional ground water. A range of representative environments for chemical residues in biota will be measured to identify the trophic levels at which bioaccumulation of toxins occur.

Progress: A 7-page article was published in the Proceedings of the 1991 National Conference of the American Society of Civil Engineers, Irrigation and Drainage Division, held July 22-26, 1991, in Honolulu.

Plans for Next Year: Final interpretive and data reports will be completed and submitted for Director's approval. Contacts and meetings will continue with appropriate Federal, State, and local agencies to discuss the results of completed studies and plan possible future investigations.

\section{Reports:}

Schrocder, R.A., Setmire, J.G., and Densmore, J.N., 1991, Use of stable isotopes, tritium, soluble salts, and redox-sensitive elements to distinguish ground water from irrigation water in the Salton Sea basin, in W.F. Ritter, ed., Proceedings of the 1991 National Conference: American Society of Civil Engineers, Irrigation and Drainage Division, Honolulu, Hawaii, July 22-26, p. 524-530. 


\section{CHANGES IN RUNOFF IN PERRIS VALLEY, RIVERSIDE COUNTY}

Number: CA472

Cooperating Agency: Riverside County Flood Control and Water Conservation District

Project Chief: Joel R. Guay

Period of Piroject: October 1988 to September 1993

Problem: Increased urbanization in Perris Valley since 1970 has caused appreciable changes in runoff characteristics. The additional impervious area has resulted in increased runoff volumes and peak discharges. Few studies have documented what effect urbanization has on runoff characteristics. Because rainfall/runoff data for Perris Valley prior to urbanization is available, a current study could determine how urbanization has affected runoff characteristics in Perris Valley.

Objectives: Compare current runoff characteristics in urbanized Perris Valley with runoff characteristics prior to urbanization.

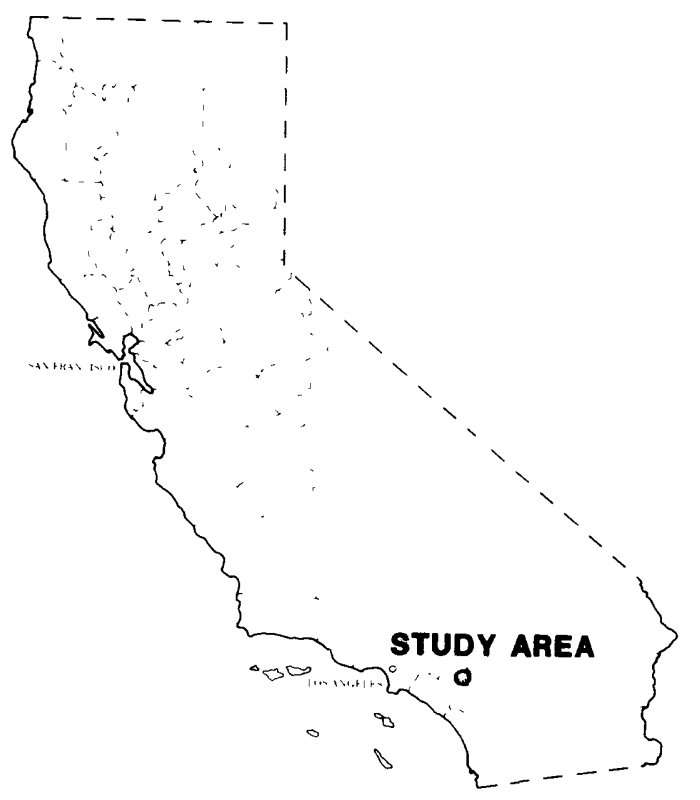

Approach: Rainfall-runoff data collected from 1989 to 1992 will be used to calibrate and verify a rainfall-runoff model. A rainfall-runoff model also will be calibrated and verified using the 1970-75 rainfall-runoff data. The results of the two models will be compared to estimate the effects of urbanization on runoff characteristics.

Progress: The rainfall-runoff model (preurbanization) for 1970-75 was completed during fiscal year 1991. A model was developed for four locations in the Perris Valley drainage basin. Simulation errors for each site were summarized as the median absolute deviation from the measured value. The simulation errors ranged from 11 to 39 percent for the runoff volumes and 11 to 33 percent for the peak discharges. Rainfall and runoff data from 10 storms were collected during fiscal year 1991. During fiscal year 1991, Perris Valley drainage basin received about 11 inches of rainfall; the 26-year average for the basin is about 11 inches. All rainfall-runoff data for the current period is stored on a computer, and work on the posturbanization rainfall-runoff model is nearly complete. Results of the first 3 years of the study were presented to the Riverside County Flood Control and Water Conservation District on October 15, 1991.

Plans for Next Year: Rainfall-runoff data will be collected for the posturbanization model, and the model will be completed. Work will begin on a comparison of storm characteristics of the preurbanization and posturbanization periods using the two rainfall-runoff models and historical rainfall data as input.

Reports: None. 


\section{WATER RESOURCES AND GEOHYDROLOGY OF THE CITY AND COUNTY OF SAN FRANCISCO}

Number: CA473

Cooperating Agency: San Francisco Water Department

Project Chief: Steven P. Phillips

Period of Project: October 1988 to September 1992

Problem: The San Francisco Water Department currently meets public supply demands by importing water from the Tuolumne River and Hetch Hetchy Reservoir in the Sierra Nevada. Expanded development of local water resources, primarily for nonpotable use, could reduce the dependency on imported water. However, better definition of the local water resources and geohydrology will be needed for future development.

Objectives: Define the water resources and geohydrology of the city and county of San Francisco. Specifically, assess water use and ground-water conditions in Golden Gate Park, Fleishhacker Zoo, and Lake Merced. Develop a work plan and cost estimate for the final phase of the study.

Approach: Literature and geohydrologic data will be reviewed and analyzed. Pumped wells will be metered by the San Francisco Water Department. The Survey will supervise tests to determine well and aquifer hydraulic characteristics. Pumping rates and water levels will be monitored. Ground-water-level recorders will be installed at suitable sites. Major-ion and isotope analyses will be done by Survey laboratories. Additional analyses to determine potable and nonpotable water use will be done by the San Francisco Water District laboratory. Geohydrologic and chemical information will help classify water types, determine surface and ground-water relations, and develop hydrologic budgets.

Progress: Major accomplishments during the past year included estimation of areal recharge throughout San Francisco, independent estimation of recharge using tritium data, continued analysis of sources of nitrate in ground water, development of a cross-sectional model of the seawater-freshwater interface, and continued development of a ground-water-flow model.

Estimates of areal recharge in San Francisco resulted from the development and calibration of an urban water-budget algorithm. These estimates compared well with independent estimates of long-term recharge rates in the Golden Gate Park area using tritium data. Areal-recharge estimates are an important part of determining the potential for development of ground water in San Francisco and are an essential element of the ground-water-flow model.

Isotopes of boron are being used to distinguish between marine and terrestrial sources of boron, which can help identify the sources of associated nitrates. High concentrations of terrestrial boron would indicate the presence of sewage, which contains detergents and cleansers. A cross-sectional model of the seawater-freshwater interface was developed along Moraga St., which is relatively simple in terms of smoothly varying topographic and bedrock surfaces, and in terms of lateral boundary conditions. A more complex cross section through Golden Gate Park will be developed on completion of the ground-water-flow model. 
Almost all input into the ground-water-flow model was completed. Depth-to-bedrock and basic surficial geology were converted to ARCINFO coverages, and most of the software required to make use of these coverages and previously compiled coverages was developed.

Plans for Next Year: The ground-water-flow model will be completed and calibrated, and a cross-sectional seawater-freshwater interface model will be developed for the Golden Gate Park area to estimate the response of the interface to additional ground-water development.

\section{Reports:}

Michel, R.L., Hamlin, S.N., and Phillips, S.P., 1991, Tritium distributions and recharge to ground water in western San Francisco, California: Eos, Transactions of the American Geophysical Union, Abstracts, v. 72, no. 44, p. 206. 


\title{
GROUND-WATER HYDRAULICS IN WOLF VALLEY, RIVERSIDE COUNTY
}

Number: CA474

\author{
Cooperating Agency: Pechanga Indian Reservation/ \\ Bureau of Indian Affairs
}

\section{Project Chief: Charles A. Kaehler}

\section{Period of Project: October 1988 to September 1992}

Problem: Population and water use are increasing rapidly in the upper Santa Margarita River basin. Rancho California Water District (RCWD), which supplies water to most of the area, will be relying more heavily on local ground-water resources to meet future water needs. In Wolf Valley, adjacent to the area served by RCWD, there is concern that RCWD pumping in the valley will cause ground-water levels to decline and will deplete ground-water storage beneath the Pechanga Indian Reservation. Much of the water for the reservation is pumped from a shallow alluvial aquifer, whereas most of the larger wells in the valley pump water from a deep aquifer.

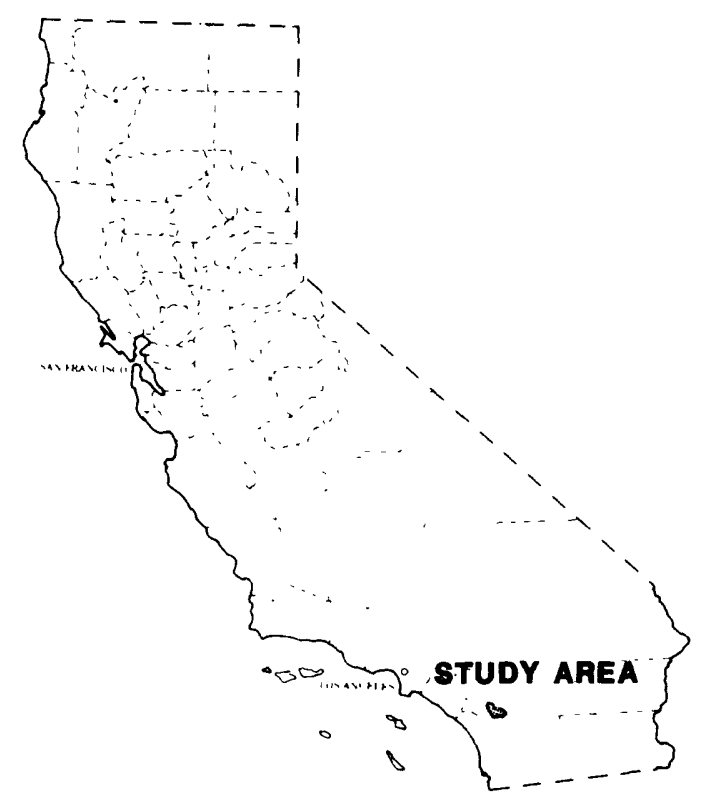

Objectives: The primary objective is to gain a greater knowledge of ground-water hydraulics in the multiple-aquifer system of Wolf Valley. The effect of pumping on ground-water levels and storage beneath the Pechanga Indian Reservation will be emphasized.

Approach: All available data on well construction, aquifer tests, subsurface geology, historical water levels, and pumpage for Wolf Valley will be collected. The existing water-level monitoring program (10 wells) will continue. All available wells will be measured in the autumn and spring of each year. Four or five test holes will be drilled to supplement existing geologic data, and the holes will be logged. Two nests of piezometers will be installed near a large production well. A long-term aquifer test (30-60 days) will measure the hydraulic properties of the shallow and deep zones as well as the confining unit. Knowledge gained on the ground-water hydraulics for the Wolf Valley aquifer system including the extent, thickness, and hydraulic properties of aquifer materials and confining layers, will be used to construct analytical solutions (distance/drawdown graphs).

Progress: During fiscal year 1991, preparations were made for the long-term aquifer test. Transducers and data loggers were installed in five piezometers to monitor pre-test water levels on an hourly basis. Several of the transducers, in continuous operation since December 1990, malfunctioned and were removed in the third quarter of the fiscal year for repair. Water levels in other piezometers and wells were measured periodically. Water levels in piezometers west of the Wolf Valley fault have been recovering since the Kelsey Tract well was tumed off in late November. Water levels in the Wolf Valley area, in general, rose an average of 1 to 2 feet in the spring. A barometric sensor was installed to determine if barometric effects will have to be accounted for in the aquifer-test data analysis. Water samples collected from several piezometers were analyzed for oxygen and hydrogen isotopes. Several problems, involving installation of the pump by the cooperator and issues concerning water supply and legal responsibilities, continued to delay the start of the long-term aquifer test. The problems apparently have been resolved, and the test has been rescheduled for January-March 1992. Single well response (slug) tests were done in 10 piezometers to obtain preliminary information on hydraulic properties of the aquifer. The information will be useful both in setting up and analyzing results of the long-term test. 
Plans for Next Year: The remainder of the study primarily will consist of a long-term aquifer test using the Pechanga well and USGS piezometers, analysis of data, construction of analytical solutions (distance/drawdown graphs) using knowledge of the aquifer system and data from the aquifer tests to evaluate possible future impacts on Kelsey Tract from large-scale pumping in Wolf Valley, and writing of a report. A digital model will not be a part of this phase of the study.

Reports: None. 


\section{EFFECTS OF NONPOINT SOURCE RUNOFF FROM ALAMEDA COUNTY ON SOUTH SAN FRANCISCO BAY}

Number: CA475

Cooperating Agency: Alameda County Flood Control
and Water Conservation District

Project Chief: Peter D. Dileanis

Period of Project: October 1988 to September 1992

Problem: Population growth in the San Francisco Bay area has caused concern about water quality in all areas of the bay. Runoff from urbanized areas adjacent to San Francisco Bay may be contributing to water-quality degradation of the bay waters. The California Regional Water Quality Control Board--San Francisco Bay Region has directed Alameda County to document contaminant loading from nonpoint sources to the bay, originating from drainage basins in the county. This project will evaluate the effects of these contaminants in the bay water and sediments in conjunction with Alameda County's study of contaminant discharges from nonpoint sources.

Objectives: Define spatial and temporal characteristics of freshwater plumes and associated suspended sediment resulting from storm flows in the three largest Alameda County tributaries to south San Francisco Bay. Determine the rate and area of dispersion of contaminants that are transported to the south bay by urban runoff from Alameda County.

Approach: Fresh water from storms discharged from San Lorenzo Creek will be monitored as it enters the bay and disperses. This will be done with automatic conductivity sensors in shallow waters and by boat-mounted sensors in deeper water. Chemical and biological constituents, such as trace metals, organic compounds, and viruses characteristic of nonpoint-source runoff will be sampled at the stream outflow and at various points in the bay to determine the dispersion of these contaminants in the bay waters and sediments.

Progress: A second year of sampling and analysis of bed sediments before and after the winter rainy season was completed at 27 sites. Concentrations of lead, mercury, and zinc are closely related to the percentage of fine particles (less than 62 micron) in the sediments, except for a few sites which seem to be enriched. Chemical and physical analysis suggest that sediments and accompanying pollutants generally are well mixed in the open shallow areas of the bay, but the embayments and narrow parts of the bay have higher percentages of fine sediments and trace-element concentrations.

Because few large storms occurred during the past several years of drought, data collection during storms was limited to one of three planned locations. Salinity and turbidity data were collected offshore of San Lorenzo Creek during five small to moderate-sized storms in 1991. A slight gradient in salinity developed along the shore, but no well-defined plume of fresh water could be detected. Mixing occurs fairly rapidly and longshore tidal currents apparently distribute the inflow considerable distances up and down the coastline. A bacteriophage tracer was released near the mouth of San Lorenzo Creek in September and was recovered successfully from numerous water samples collected offshore during a 10 day period. Although release of the tracer occurred during low flow, it did provide important data on offshore transport and demonstrated the feasibility of using the tracer to monitor storm-water transport. Because of unforeseen delays in the development of the bacteriophage tracer and a concurrent drought which severely limited storm runoff, the study was extended through fiscal year 1992.

Plans for Next Year: Work with the bacteriophage tracer will be completed, and, given a break in the drought, data will be collected during high flows into the bay.

Reports: None. 


\section{DEVELOPMENT OF SACRAMENTO RIVER BED-SCOUR RELATION AT THE SR-32 BRIDGE AT HAMILTON CITY}

Number: CA476

Cooperating Agency: California Department of
Transportation

Project Chief: James C. Blodgett

Period of Project: October 1988 to September 1992

Problem: Exposure or undermining of the bridge pier and abutment foundations from the erosive action of flowing water at the State Route 32 bridge at Hamilton City, California, can result in bridge failure or the need for expensive repairs. Bridge-scour data are difficult to obtain, partly because major scour usually occurs during flood conditions. As a result, actual measurements of scour that can be used to define significant bridge and channel characteristics in causing scour and comparison of scour data with laboratory derived relations are

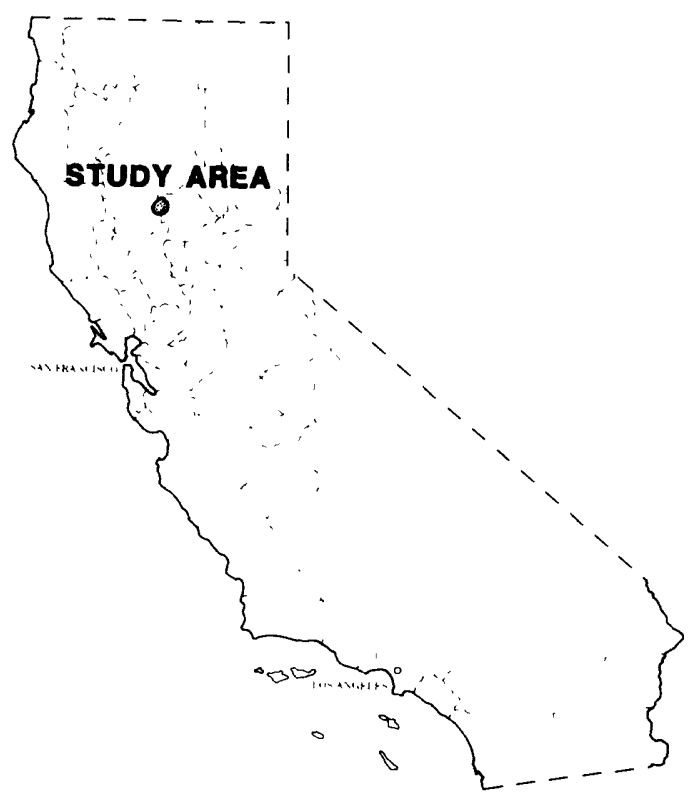
needed.

Objectives: Determine those hydraulic and bridge geometric factors that are important in the cause and extent of channel-bed scour. Develop equations to predict depth and lateral extent of scour at the old and new bridges and compare these equations with scour equations for other sites. Determine the rate of channel stabilization associated with constriction and local scour at the new bridge.

Approach: Channel-survey data obtained near the old bridge site will be used to relate bridge geometry and to indicate typical channel conditions. Scour and hydraulic data at the new bridge will be collected about four times per year and stored: once before the flood season, twice during the flood season, and once after the flood season. Geophysical soundings will be obtained annually to provide information on the maximum depth of scour below the surveyed channel bed. Data will be analyzed and separated into the components of channel bed, constriction, and local scour. Constriction and local scour will be related to bridge geometry.

Progress: Channel and bridge-scour data were collected in November 1990 and March and May 1991. New survey and sounding equipment that provides data in the $\mathrm{x}, \mathrm{y}$, and $\mathrm{z}$ planes was used to provide scour data at the new SR-32 site, which is 100 feet downstream from the old bridge site. Flooding did not occur during the 1991 water year, so data needed for analysis of scour conditions during high-flow conditions at the site are unavailable.

Plans for Next Year: Collection of scour depth and channel-geometry data will continue with emphasis on collecting scour data during several moderately high-flow events. If suitable floods occur, scour data will be collected around the bridge piers. An evaluation of previously collected scour data, especially that collected at the old bridge site, will be completed, and a final report will be prepared if sufficient flooding occurs so that an adequate range of data can be obtained. If flooding does not occur during the winter of 1991-92, an extension will be requested to obtain an additional year of data collection.

Reports: None. 


\section{GROUND-WATER RESOURCE INVESTIGATIONS, EDWARDS AIR FORCE BASE}

Number: CA477

Cooperating Agency: U.S. Air Force, Edwards Air Force Base

Project Chief: Devin L. Galloway

Period of Project: Continuing

Problem: Declining water levels, an apparent decrease in water quality, and an antiquated water-distribution system have resulted in a water shortage at Edwards Air Force Base. In addition, there has been widespread land-surface subsidence in the southwest part of the base; and an extensive system of cracks, fissures, and potholes has developed on Rogers Lake (dry). This has generated concern about the condition of runways on the lakebed.

Objectives: Define the boundaries and areal extent of

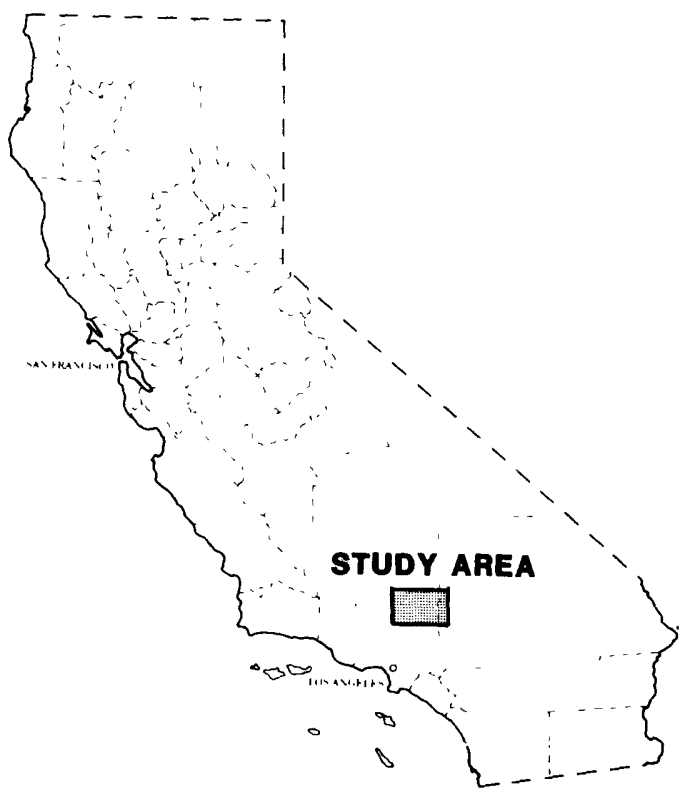
the ground-water system. Quantify the distribution of hydrologic properties. Determine ground-water recharge and discharge. Define the aquifer water types. Develop a long-term ground-water monitoring program. Identify sites for development of future well fields. Determine the influence of surface-water floodflows on the morphology of the playa surface. Determine the areal extent and amounts of land-surface subsidence. Determine the extent and cause(s) of fissures, cracks, and potholes on the lakebed. Evaluate the effect of these fissures and cracks on the geomorphology of existing stream networks entering and on the lakebed. Determine measures that may be used to control or prevent lakebed cracking and possibly hasten lakebed repair by natural means.

Approach: Gravity, seismic refraction, and direct current resistivity methods will be used to identify the geologic structure and boundary conditions of the ground-water basin. Exploratory drilling will be done. Water-quality samples will be collected. Piezometers will be installed at various levels to establish a multilevel monitoring network. Aquifer tests will be done. Well-field hydraulics will be modeled. Waterlevel and water-quality data for wells on and adjacent to the airbase will be inventoried and collected. Evidence of land subsidence and surface deformation will be obtained by spirit-level and Global Positioning System (GPS) surveys, acrial photography of the lakebed, and monumentation of selected fissures. Extensometers will be installed to measure the amount and rate of subsidence at selected locations.

Progress: Exploratory test drilling was done at nine sites in the Rogers Lake area of the base, and 33 piezometers were installed at these sites to monitor water levels and water quality. Existing wells on the base were inventoried; and pumpage data from the base supply wells were collected. Several survey lines were run in the Rogers Lake area to determine the shape of the lakebed. Mapping of the geology of the base was begun by personnel from Geologic Division.

Since 1957, water levels in the Rogers Lake area of the base have declined from 30 to 90 feet with the greatest decline occurring in the area of the South Track well field. This area of greatest water-level decline corresponds with the area of greatest measured land subsidence, which was about 3.5 feet from 1961 to 1989.

A north-south survey line that was run down the middle of Rogers Lake bed indicated that the north end of the lakebed is 5 feet higher than the south end. Most of this change in elevation occurs across a short distance in the south base area. 
Plans for Next Year: Several exploratory test holes will be drilled and equipped with multiple piezometers. Seismic surveys will be done at selected locations on Rogers Lake bed and in the Hospital Ridge area. An extensometer will be installed near the fissure on the southeast side of the lakebed. The survey of the lakebed will be completed and a map of the lakebed surface will be prepared. Samples from selected wells on base will be collected and analyzed for water quality. A ground-water-monitoring network will be established.

\section{Reports:}

Blodgett, J.C., and Galloway, D.L., 1991, Measurement of land subsidence using GPS surveys: Edwards Air Force Base, Antelope Valley, California: Eos, Transactions of the American Geophysical Union, Abstracts, v. 72 , no. 44 , p. 118.

McCaffrey, W.F., and Rewis, D.L., 1991, Significance of lacustrine sediments underlying Edwards Air Force Base and vicinity, California, to ground-water movement: Geological Society of America Abstracts with program, v. 2, no. 5, p. 27.

Rewis, D.L., and McCaffrey, W.F., 1991, Hydrogeologic evaluation of Edwards Air Force Base, California using geophysical data: Geological Society of America, Abstracts with program, v. 23, no. 5, p. 124. 


\section{EVALUATION OF SUBSIDENCE RATES AND PROCESSES IN SURFICIAL PEAT, SACRAMENTO-SAN JOAQUIN DELTA}

Number: CA479

\section{Cooperating Agency: California Department of Water Resources}

\section{Project Chief: Steven J. Deverel}

Period of Project: October 1989 to September 1993

Problem: The Sacramento-San Joaquin Delta islands and tracts have been subsiding because of oxidation of organic soils at a rate of 1 to 3 inches per year since the drainage of the islands and tracts began in the early part of this century. Continued subsidence threatens the integrity of the levee system and will increase the amount of energy required to maintain a low water table for crop production. Knowledge of the processes contributing to subsidence of these soils will provide a basis for waterand land-management strategies to mitigate subsidence.

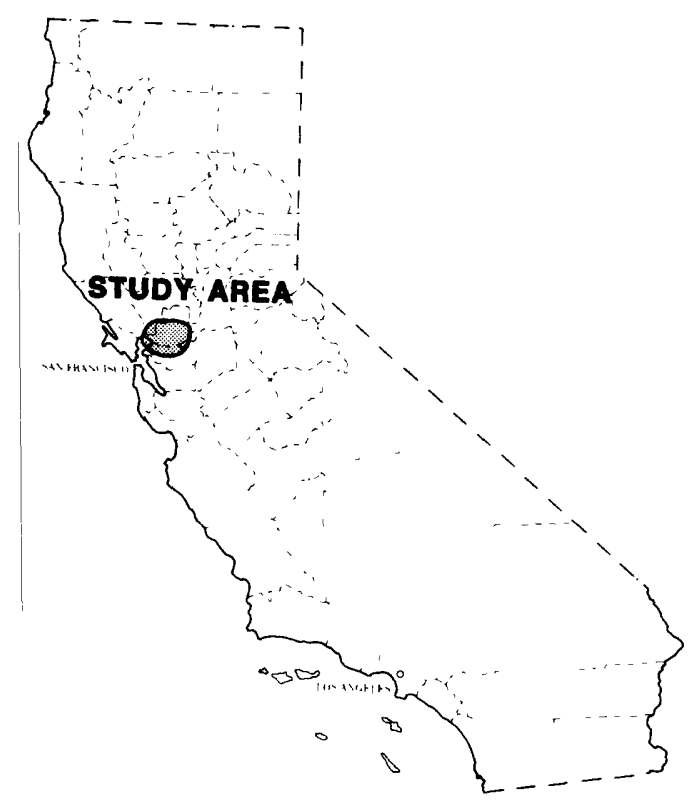

Objectives: The overall goal of this study is to better understand the factors which affect organic soil loss in the Sacramento-San Joaquin Delta. Specifically, the objectives are to: (1) quantify subsidence rates in organic soils at selected locations; (2) identify and quantitatively assess hydrologic and geochemical processes which affect carbon loss under different landand water-management practices; and (3) assess the spatial and temporal variability of carbon loss.

Approach: An attempt will be made to quantify the processes contributing to carbon loss from the organic soils at several agricultural sites in the delta. Two of these processes are (1) respiration of organic carbon and (2) dissolution and mobilization of aqueous-dissolved and particulate organic carbon. These processes will be assessed in conjunction with subsidence measurements at each site. A carbon mass-balance approach will be taken at each site to reconcile subsidence with carbon loss.

Progress: Monitoring of land-surface elevation changes and gaseous and aqueous carbon-dioxide fluxes during fiscal year 1991 allowed for improved quantification of the carbon budget and of the causes of subsidence. Measurements made during 1990 and 1991 show that gaseous carbon-dioxide fluxes vary seasonally and are influenced primarily by temperature and secondarily by soil moisture and soil-organic-matter content. The evolving carbon dioxide is a mixture of carbon dioxide derived from organic-matter oxidation and plant root respiration. Carbon-13 and carbon-14 determinations in carbon-dioxide samples indicated that the organic-matter oxidation represented from 40 to 100 percent of the carbon-dioxide flux. Land-surface elevation changes, determined with extensometers, are influenced primarily by hydraulic-head changes. Net subsidence rates were $1.49,1.06$, and 1.51 centimeters per year on Jersey Island, Orwood Tract, and Sherman Island, respectively. In all three cases, subsidence calculated from gaseous carbon-dioxide losses due to organic-matter oxidation, is in reasonable agreement with measured subsidence indicating that organic-matter oxidation is the primary mechanism of carbon loss. Estimates of dissolved organic-carbon fluxes for all three sites were small relative to gaseous carbon-dioxide losses and seem to represent less than 1 percent of the measured subsidence. 
Plans for Next Year: Monitoring of gaseous and aqueous carbon-dioxide fluxes will continue to further refine the carbon budget for the individual fields and to provide more information about temporal variability of subsidence. Experiments are planned to provide information about the spatial and temporal variability of carbon-dioxide fluxes. Soil sampling and laboratory experiments will be done to assess processes causing spatially variable subsidence throughout the delta.

\section{Reports:}

Neil, J.M., and Devere1, S.J., 1991, Atmospheric carbon input from decomposing peat soils of the Sacramento-San Joaquin Delta, California, in Global change and biogeochemistry of radiative trace gasses: International Symposium on Environmental Biogeochemistry, 10th, San Francisco, California, August 19-23, Abstracts. p. 30-31. 


\section{NITRATE IN THE HEMET GROUND-WATER SUBBASIN}

Number: CA480

Cooperating Agency: Eastern Municipal Water District

Project Chief: Terry F. Rees

Period of Project: January 1990 to September 1993

Problem: Nitrate concentrations in ground water from many basins in southern California approach or exceed the drinking-water standard of $\mathbf{4 5}$ milligrams per liter. High nitrate concentrations are due primarily to agricultural land- and water-use practices involving, for example, dairies, citrus groves, and irrigation with reclaimed water. In order to manage the ground-water resources and to identify future mitigating measures; the chemical, biological, and hydraulic processes that affect nitrogen speciation and concentration need to be determined for a variety of representative land-use and hydrologic conditions.

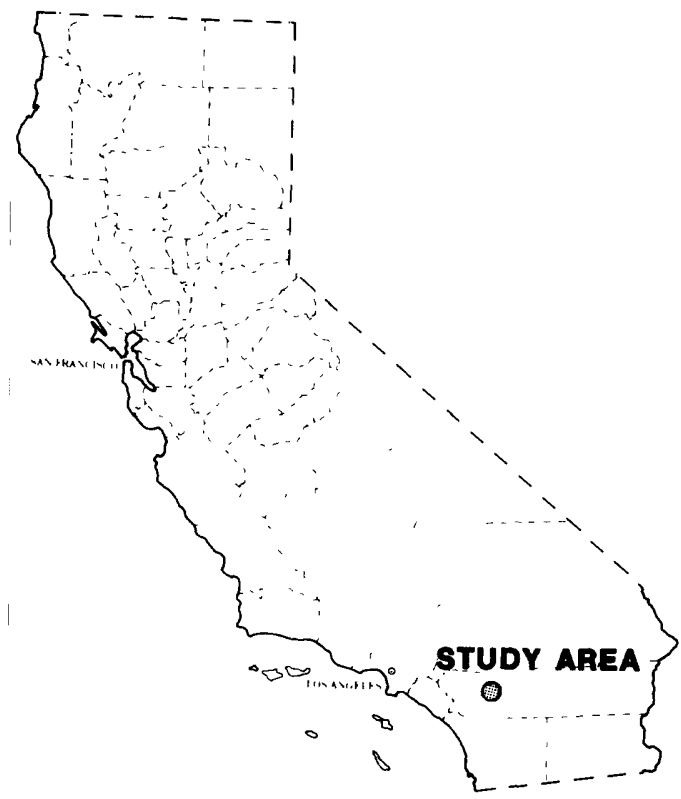

Objectives: Define current ground-water conditions in the Hemet subbasin, including thickness and extent of water-bearing materials, direction of ground-water flow, and chemical quality of ground water. Determine the effects of chemical, biological, and hydraulic processes on nitrogen speciation and concentration in the unsaturated zone. Determine the quantity of nitrate reaching the water table. Determine the degree of mixing and vertical distribution of nitrate in the saturated zone.

Approach: A detailed study will be done at six sites that have hydrologic and land-use conditions representative of southern California basins: (1) a residential area; (2) an area using reclaimed water; (3) a citrus grove; (4) an agricultural area; (5) a poultry operation; and (6) a dairy feedlot. Instrumentation will include neutron access tubes, suction-cup lysimeters installed above the water table, soil-gas sampling tubes, and nested piezometers installed below the water table. Physical and hydrogeologic characteristics, common chemical concentrations, selected radioisotopes and stable isotopes, and bacteria will be studied.

Progress: All phases of the site installations were completed December 5, 1990. In addition to the six sites originally selected and instrumented, an additional dairy site in the Chino basin was instrumented. The purpose of this additional site is to allow comparison between an old dairy (Chino basin) as related to a young dairy (Hemet subbasin) and a dairy with relatively thick unsaturated zone (Chino) and a shallow unsaturated zone (Hemet). Bacterial characterizations and basin lithologic descriptions were completed March 20,1991. An initial inventory of 70 basin wells for determination of water-table elevation and water quality was completed during March 1991. The first semiannual Cooperator Information Meeting was held May 6, 1991. Core materials were analyzed for particle-size distribution and for porewater content and chemistry. Hydrogen-isotope analyses on porewater and saturated-zone water were done to determine the rate at which water is moving through the unsaturated zone and to aid in determining the age of the saturated-zone water. Quarterly water-quality samples were collected during March, June, and September 1991.

Plans for Next Year: Journal reports describing the results of the bacterial characterizations and the porewater chemistry of the core material will be prepared during first quarter of fiscal year 1992. Results of water-quality sampling will be analyzed to delineate zones in which apparent denitrification is occurring. For these zones, extensive soil-gas analyses and nitrogen- and oxygen-isotope evaluations will be done. All field sampling will be completed by the end of fiscal year 1992. Cooperator information meetings are scheduled for early December 1991 and early May 1992.

Reports: None. 


\section{PROCESSES GOVERNING THE DISTRIBUTION AND MOBILITY OF SELENIUM AND ARSENIC IN SHALLOW GROUND WATER, TULARE BASIN}

Number: CA481

Cooperating Agency: California Department of Water
Resources

Project Chief: Roger Fujii

Period of Project: October 1989 to September 1993

Problem: Large parts of the Tulare basin are being affected by shallow ground water, leading to a need for subsurface drainage for continued agricultural production. Disposal of agricultural drainwater in evaporation ponds and potential downward migration of contaminated, shallow ground water to regional aquifers have been a source of concern for migratory waterfowl and human health because of the high concentrations of arsenic and selenium in the drainwater. The diversity and contrast of depositional environments has contributed to the highly

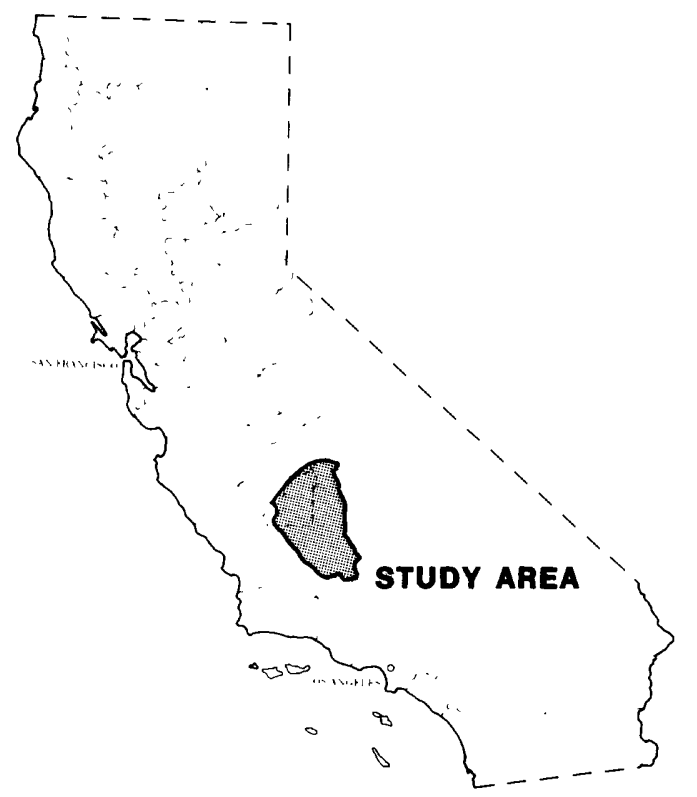
variable concentrations of arsenic and selenium in shallow ground water throughout the basin.

Objectives: Compare distribution of arsenic, selenium, and other selected elements in ground water and sediments at four locations in subareas of the Tulare basin. Identify potential geochemical, biological, and hydrologic processes controlling the solubility and mobility of arsenic and selenium at each location. Compare and contrast the potential influence of key processes between the subareas. Determine the necessary studies to comprehensively evaluate the geochemical, biological, and hydrologic processes governing solubility and mobility of arsenic and selenium for the subareas in this basin.

Approach: The distribution of arsenic and selenium in ground water and sediments will be evaluated at four locations in the basin. At each site, 20-, 50-, 100-, and 200-foot wells will be drilled and sampled. During drilling of the 100-foot well, a continuous core will be taken and porewater and sediments will be analyzed every 5 to 10 feet. Samples will be analyzed for arsenic, selenium, and other trace and major constituents. Water levels will be monitored. These data will help to define the key processes that affect the mobility of arsenic and selenium and to form the basis for further studies in the basin.

Progress: A preliminary evaluation of the results of analyses of observation-well and porewater samples was done for one well-cluster site in the southern Tulare Lake bed subarea and one well-cluster site in the Wheeler Ridge subarea. Results of selenium analyses show (1) a high correlation between high concentrations of selenium and specific conductance, (2) selenate specie dominates (90 percent), and (3) oxygen-18 and deuterium analyses indicate shallow ground water has been affected by evaporative processes. Results suggest that the distribution of selenium and salinity in upper ground water at both sites seems to be the result of evaporation of shallow ground water followed by irrigation and leaching. Concentrations of arsenic in samples from the southern Tulare Lake bed site were higher than at the Wheeler Ridge site. These differences probably are related to several complex geochemical and hydrologic influences, such as differences in depositional environments, sediment sources, redox conditions, and ground-water hydrology. Results of phosphate extractions of sediment samples indicate that substantial proportions of arsenic in sediments are present in labile forms. Field activities for this year consisted of installing two additional well clusters in the southern Tulare Lake bed subarea. 
Plans for Next Year: Observation wells installed last fiscal year will be sampled for water-quality analyses. Two or three new well clusters will be installed and sampled in the Wheeler Ridge subarea to evaluate the ground-water geochemistry of selenium, salinity, and other trace elements as well as the local ground-water hydrology. Detailed analyses of selected sediments collected during drilling will be analyzed to discern the solid-phase associations of trace elements in relation to potential availability to ground water. Results from analyses of observation-well, porewater, and sediment samples in conjunction with a preliminary evaluation of the local ground-water hydrology for the southern Tulare Lake bed area will be published in an interpretive report.

\section{Reports:}

Beard, Sherrill, Phillips, S.P., and Gilliom, R.J., 1991, Estimation of the constituent load of groundwater inflow to the San Joaquin River, California: Eos, Transactions of the American Geophysical Union, Abstracts, v. 72, no. 44, p. 187.

Fujii, Roger, and Dickson, A.T., 1991, Distribution of Se and As in ground water, Tulare basin, California (abs.): Soil Science Society of America, Annual Meeting, Denver, Colorado, October 27November 1, 1991, Program. 


\section{INTERACTION OF GROUND-WATER FLOW AT REGIONAL, SUBREGIONAL, AND FARM SCALES, AND IMPLICATIONS FOR DRAINWATER FLOW AND QUALITY, WESTERN SAN JOAQUIN VALLEY}

Number: CA482

Cooperating Agencies: Panoche Water and Drainage District; and California Department of Water Resources

Project Chief: John L. Fio

Period of Project: October 1989 to September 1992

Problem: In the western San Joaquin Valley, more than 250,000 acres of irrigated farmland require drainage because of severe soil salinity and a shallow water table. Shallow ground water and drainwater in these areas have toxic levels of boron, molybdenum, and selenium associated with high concentrations of dissolved solids. Preliminary data indicate that ground-water flow to drainage systems in the valley and resultant contaminant loads are affected by local, subregional, and regional hydrologic response to stresses. Management strategies designed to control drainwater flow and quality must address the interrelations at all three scales.

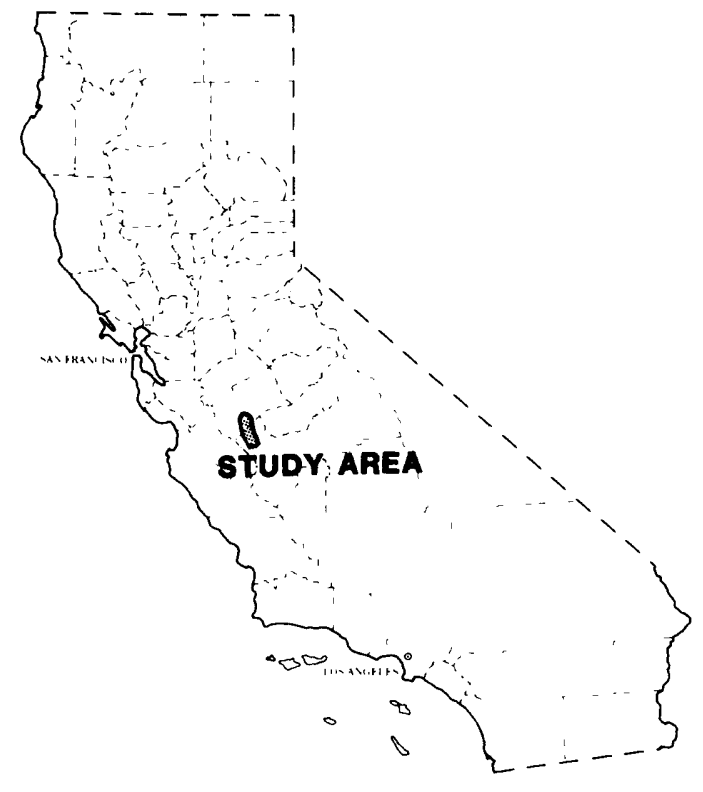

Objectives: Develop and verify a subregional-scale ground-water-flow model that simulates steady-state drainflow and drainwater chemistry. Quantitatively assess the interactions among the regional, subregional, and local ground-water-flow systems in response to irrigation and drainage. Evaluate the effects of potential local and larger-scale management actions on drainwater flow and quality. Assess implications for development of a field and modeling approach for the quantitative assessment of ground-water flow and contaminant movement in other irrigated and drained agricultural areas in which local- and regional-scale interactions must be evaluated.

Approach: A three-dimensional, finite-difference ground-water-flow model will be developed for the subregional flow system within the Panoche Water District in the western valley. Geohydrologic data from observation wells will be used to develop and calibrate the subregional model. Qualitative verification of simulated ground-water flow to the drainage systems will be made using geochemical data from ground-water and drainwater samples. Comparison of results from the subregional model and the Survey's regional-flow model of the western valley will assist the interactions between the two scales.

Progress: A three-dimensional, finite-differential ground-water-flow model was completed for the study area. Model results and hydrologic and geochemical data were used to assess subregional ground-water flow to drainage systems in the western San Joaquin Valley, California. Results showed that ground-water-flow characteristics vary depending on position on the alluvial fans in the study area. At the highest elevations, the water table is at depths greater than 10 feet below land surface and drainage systems are not present. Ground-water flow in these areas is predominantly downward. In contrast, at the lower elevations having drainage systems and a water table within 10 feet of land surface, ground-water flow is predominantly upward. In the midfan areas, changes in hydraulic head with depth are minimal, and substantial horizontal movement of ground water can occur. Geochemical and isotopic data from ground-water samples indicate that shallow ground water was enriched in stable isotopes by partial evaporation from the shallow water table. Isotopically enriched ground water has the greatest concentrations of salts and selenium. In areas of downward flow, the distribution of soluble constituents 
is fairly constant with depth; but where flow is predominantly upward, the depth distribution of chemical constituents show a distinctive geochemical profile. Salt and selenium loads depend on the depth distribution of constituents and local hydrologic conditions associated with irrigation and drainage.

Plans for Next Year: A quantitative assessment of ground-water flow using a three-dimensional, ground-water-flow model will continue. Preparation of the final report will be completed.

Reports: None. 


\section{OPTIMUM CONTROL OF SEAWATER INTRUSION, OXNARD PLAIN, VENTURA COUNTY}

Number: CA483

Cooperating Agency: United Water Conservation
District

Project Chief: Eric G. Reichard

Period of Froject: October 1989 to September 1993

Problem: Seawater intrusion beneath the Oxnard Plain threatens the water supply in Ventura County. There is a need to improve the understanding of the processes of seawater intrusion in the multiaquifer system and to develop management plans for controlling intrusion.

Objectives: Apply and demonstrate the usefulness of solute-transport and hydraulic-optimization modeling techniques in evaluating various management options to control seawater intrusion in a multiaquifer system.

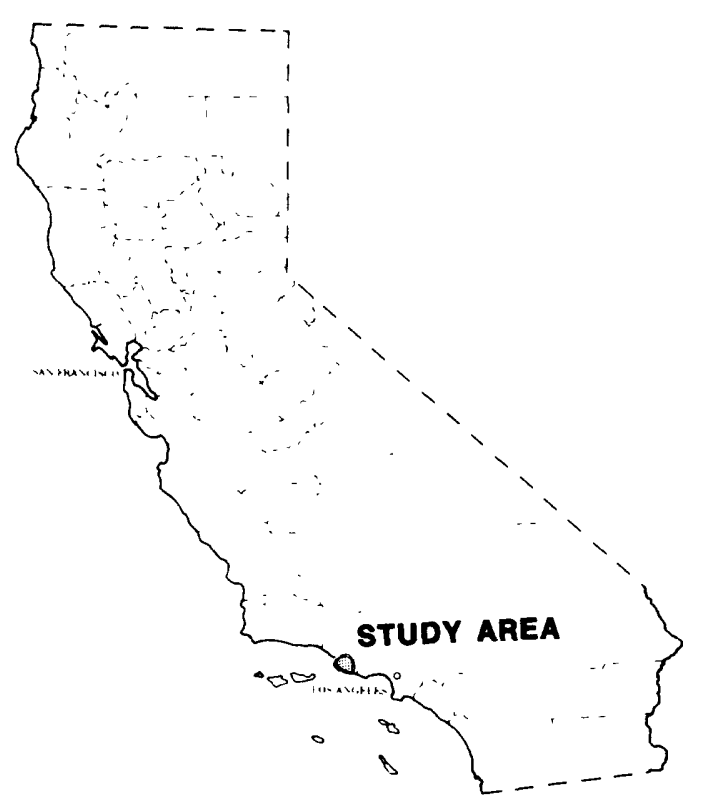

Approach: The study tasks are to drill and collect data from nested test wells in the Oxnard Plain, to analyze the data to develop a conceptual model of the three-dimensional geohydrologic system, to develop a three-dimensional transport model of seawater intrusion, and to develop a set of simulation optimization models for evaluating alternative strategies for controlling seawater intrusion.

Progress: Work completed in the second year of the study included monitoring well drilling, data collection, and model development. Eight additional nested monitoring wells were drilled. Water-level and water-quality data were collected from all the USGS wells, including the 11 drilled in FY90, and from existing non-USGS wells in the basin. A preliminary simulation flow model was linked to mathematical optimization software. The linked model was used to evaluate alternative scenarios for managing seawater intrusion. Work began on applying a three-dimensional transport model to simulate seawater intrusion in the Oxnard Plain. All tasks for this study have been carried out in close cooperation with the Southern California RASA.

Plans for Next Year: Analyses of previously collected data and development of the two models will be completed: the three-dimensional transport model of seawater intrusion and the second-phase management model (linking the RASA regional-flow model with optimization software).

\section{Reports:}

Reichard, E.G., and Martin, Peter, 1991, The role of ground-water modeling in the design of management plans for the control of seawater intrusion: Geological Society of America, Cordilleran Section Meeting, 87th, San Francisco, March 25-27, Abstracts with programs, p. 91.

Reichard, E.G., and Nishikawa, T., 1991, Management of seawater intrusion in Ventura County, California: A multistep simulation-optimization approach: Eos, Transactions of the American Geophysical Union, Abstracts, v. 72, no. 44, p. 201. 


\section{SAN FRANCISCO BAY-ESTUARY TOXIC CONTAMINANT STUDY}

Number: CA484

Cooperating Agency: None. (U.S. Geological Survey Federal Program)

Project Chief: Kathryn M. Kuivila

Period of Project: March 1990 to September 1995

Problem: Estuaries are among the most heavily used of the Nation's surface-water resources and are particularly susceptible to contamination by toxic substances. The San Francisco Bay estuary receives a broad range of organic contaminants that vary widely in their sources, seasonality, toxicity, and environmental behavior. Despite an increasing awareness of potential contamination issues, the effect of organic contaminants in the estuarine environment is not fully understood.

Objectives: Determine how organic contaminants from riverine and local sources are transported and react in the estuary under varying hydrologic conditions. Determine the ultimate fate of these organic contaminants within the estuary. Develop methods to detect and quantify ecological responses to the presence of organic contaminants in the estuary.

Approach: Present data on pesticide use and waste discharges will be synthesized to select specific organic contaminants for sampling and analysis. Various sampling techniques will be used, including fixed-site monitoring and synoptic studies to provide a consistent record of river-transported contaminants. Certain hypotheses on contaminant distribution during specific hydrologic and contaminant-loading conditions will be tested. Bottom sediment and biota will be collected and analyzed to define the distribution of these contaminants and their partitioning between water, sediment, and biota.

Progress: Three de-watering methods were used to concentrate large volume samples from Suisun Bay for suspended sediments: a hollow-fiber tangential flow device, continuous-flow centrifuge, and Pellicon ultrafiltration. Partitioning between sediments and water was examined by analyzing the samples for pesticides. Water sampling for pesticides began in January; samples were collected three times a week at the mouths of the San Joaquin and Sacramento Rivers. The results of this monitoring emphasize the highly seasonal temporal nature of the pesticide inputs. A study of the pesticides used on almond orchards in February suggested that low concentrations of diazinon entered the delta but were not transported into Suisun Bay. Fixed sites in the delta were sampled for pesticides used on alfalfa fields in April and May. Carbofuran concentrations increased seaward, suggesting input from local deltaic sources and possible transport into Suisun Bay. The transport of pesticides from rice fields was studied in June and July. Results were presented at the 4th Toxic Substances Hydrology Meeting as two talks and two posters. In addition, a field trip was organized for the meeting and a field trip guide was compiled. Study results also were presented during a briefing for the Director of the U.S. Geological Survey and at seminars of the Geological Society of America meeting at University of Califomia, Davis, at a San Francisco Bay Symposium, and in Reston. An article was written for the Director's yearbook.

Plans for Next Year: The above studies will be continued with more emphasis on the transport and transformation of pesticides used on alfalfa and rice. An areal reconnaissance will be made of suspended and bed sediments and the pesticides adsorbed into them within the delta. 


\section{Reports:}

Crepeau, K.L., Kuivila, K.M., and Domagalski, J.L., 1991, Riverine inputs of pesticides to the Sacramento-San Joaquin Delta, California (abs.): Biennial International Conference of the Estuarine Research Federation, 11th, San Francisco Bay and Delta special session, San Francisco, November 10-14, 1991, Program.

Domagalski, J.L, and Kuivila, K.M., 1991, Transport and transformation of dissolved rice pesticides in the Sacramento River Delta, California, in Mallard, G.E., and Aronson, D.A., compilers, U.S. Geological Survey Toxic Substances Hydrology Program--Proceedings of the technical meeting, Monterey, California, March 11-15, 1991: U.S. Geological Survey Water-Resources Investigations Report 91-4034, p. 664-666.

Domagalski, J.L., and Kuivila, K.M., 1991, Transport and transformation of dissolved rice pesticides in the Sacramento River delta, California, in Mallard, G.E., and Aronson, D.A., compilers, U.S. Geological Survey Toxic Substances Hydrology Program--Abstracts of the technical meeting, Monterey, California, March 11-15, 1991: U.S. Geological Survey Open-File Report 91-88, p. 117.

Domagalski, J.L, Kuivila, K.M., and Crepeau, K.L., 1991, Transport and transformations of dissolved and particle-bound pesticides in the San Francisco Bay Estuary, California (abs.): Biennial International Conference of the Estuarine Research Federation, 11th, San Francisco Bay and Delta special session, San Francisco, November 10-14, 1991, Program.

Kuivila, K.M., and Domagalski, J.L., 1991, Organic contaminants in San Francisco Bay-Estuary (abs.): Geological Society of America, Cordilleran Section Annual Meeting, San Francisco, March 25-27, 1991, Program.

Kuivila, K.M., and Nichols, F.H., 1991, Overview of San Francisco Bay estuary toxic contaminants study in Mallard, G.E., and Aronson, D.A., compilers, U.S. Geological Survey Toxic Substances Hydrology Program--Proceedings of the technical meeting, Monterey, Califomia, March 11-15, 1991: U.S. Geological Survey Water-Resources Investigations Report 91-4034, p. 659-663.

Kuivila, K.M., and Nichols, F.H., Overview of San Francisco Bay estuary toxic contaminants study, in Mallard, G.E., and Aronson, D.A., compilers, U.S. Geological Survey Toxic Substances Hydrology Program--Abstracts of the technical meeting, Monterey, Califomia, March 11-15, 1991: U.S. Geological Survey Open-File Report 91-88, p. 116. 


\title{
SAN JOAQUIN-TULARE BASINS NATIONAL WATER QUALITY ASSESSMENT PROGRAM
}

Number: CA485

\author{
Cooperating Agency: None. (U.S. Geological Survey \\ Federal Program)
}

\section{Project Chief: Neil M. Dubrovsky}

\section{Period of Project: Continuing}

Problem: The quality of the Nation's water is being degraded by various human and natural processes. A large amount of water-quality data has been collected to assess the impact of point sources and compliance with regulations. In contrast, the impact of nonpoint sources is significant but rarely studied. Existing data generally are inadequate to assess the status and trends in water quality of large regions and the Nation. Additional data need to be collected to address questions about water quality and to determine the effect of regulatory practices and past water-quality management decisions.

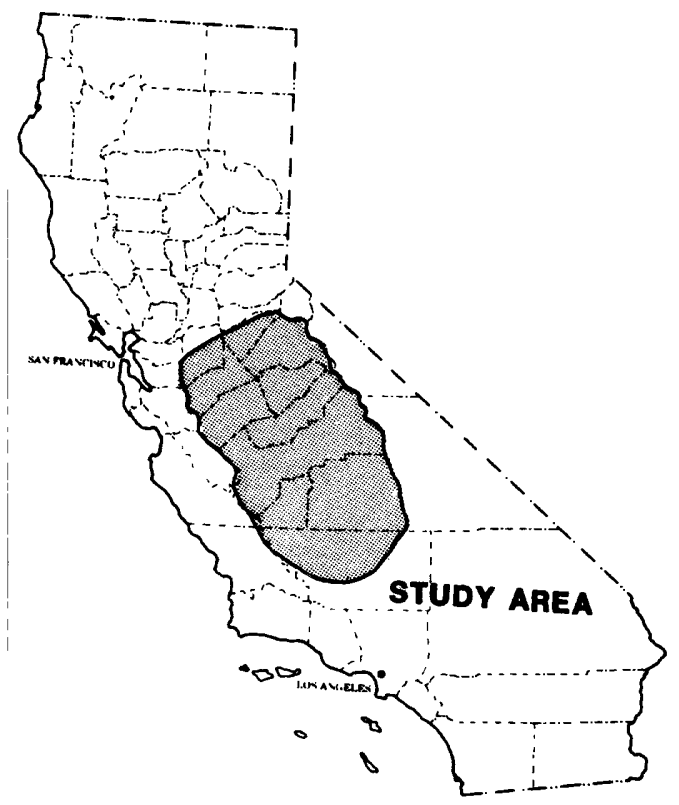

Objective: (1) Provide a description of current water-quality conditions consistent with the needs of the national level synthesis of the data; (2) define long-term trends (if any) in water-quality data; and (3) identify, describe, and explain to the extent possible the major human and natural factors that affect observed water-quality conditions and trends. Key factors of concern in the study unit are concentrations of pesticides, nutrients, and naturally occurring trace elements in surface and ground water; and surface-water salinity.

Approach: During the first phase an extensive retrospective analysis of the status and trends in water quality and aquatic ecology will be done using existing data. A reconnaissance will be done concurrently to collect data on aspects of water quality for which little or no data exists. These two activities will identify areas where there is insufficient data for water-quality assessment and will provide the basis for design of a 3-year intensive data-collection phase. A long-term network will be a carefully selected subset of the stations sampled in the intensive phase.

Progress: During fiscal year 1991, efforts were directed at four activities: assembling a liaison committee, acquiring staff, defining and prioritizing issues, and writing a workplan for fiscal year 1992. The first liaison committee meeting was held in May. Representatives from 35 agencies were given descriptions of the national and study-unit scale goals and the structure of NAWQA (National Water-Quality Assessment Program). A dialogue on identification and prioritization of major water-quality issues in the study unit also was begun. This dialogue was the main topic of the second meeting, held in September. The study unit staff, assembled in fiscal year 1992, consists of the project chief (ground-water quality), an organic geochemist, a surface-water-quality specialist, an aquatic biologist, a data-base manager, and a lead technician. The workplan prepared for fiscal year 1992 focused on a conceptual model for water quality in the study unit, identification and prioritization of major water-quality issues, the approach to the retrospective analysis, and reconnaissance activities.

Plans for Next Year: During fiscal year 1992, efforts will focus on the retrospective analysis of existing water-quality data; reconnaissance studies of issues which have little data existing; and preparation of a workplan for the intensive data-collection phase that will start in fiscal year 1993. Because of the large amount of water-quality data available, subjects for the retrospective analysis will be prioritized on the 
high priority include concentrations of pesticides in surface and ground water, sediment and salinity in surface water, and nutrients in ground water. A draft plan for reconnaissance studies is in review. Results of fiscal year 1992 activities will be used to prepare the fiscal year 1993-95 workplan. This workplan will be an evolutionary document that will become more detailed as understanding of the study-unit hydrology and water quality improves.

\section{Reports:}

Dubrovsky, N.M., 1991, National Water-Quality Assessment Program--The San Joaquin-Tulare Basins: U.S. Geological Survey Open-File Report 91-153, 2 p. (Water Fact Sheet) 


\section{APPRAISAL OF WATER RESOURCES IN THE WAWONA AREA OF YOSEMITE NATIONAL PARK WITH EMPHASIS ON THE AVAILABILITY OF GROUND WATER}

Number: CA486

Cooperating Agency: National Park Service

Project Chief: James W. Borchers

Period of Project: October 1990 to March 1993

Problem: The 1980 General Management Plan for Yosemite National Park recommends relocating the park and concessioner headquarters and most employee housing out of Yosemite Valley. Most of the relocations have not taken place because of questions regarding water supplies at El Portal and Wawona. Currently, most water used in Wawona is from the south fork of the Merced River, but this source of water does not adequately meet present demands during low riverflows. Alternative water sources need to be determined. Minimal information exists on ground water and springs in the fractured granitic rocks underlying the Wawona area.

Objective: Examine potential for water-resources development in the Wawona area of Yosemite National Park.

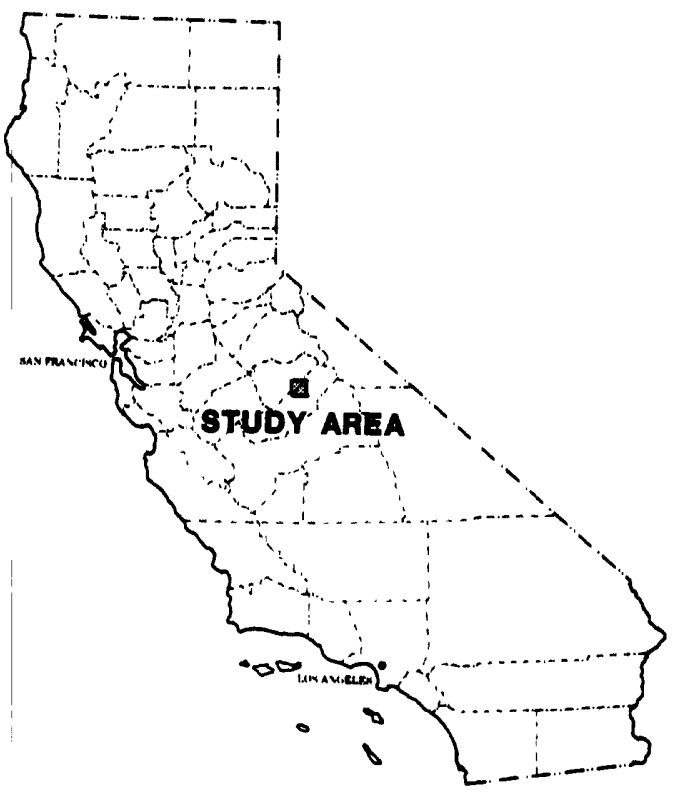
The investigation will focus on defining the hydrogeologic framework of the ground-water-flow system of the South Fork, Merced River valley, near Wawona. Development of an adequate water supply may require conjunctive use of surface and ground water and importation of water from outside the Wawona area. Evaluate existing data to determine the relation between streamflow and ground water in the Wawona area and the reliability of nearby springs as a source of supply.

Approach: A reconnaissance study will be done to: (1) develop a conceptual model of the fracturecontrolled flow system using existing data, (2) collect data to refine the model, and (3) use the model to evaluate the ground-water system as a source of supply. Refinement of the conceptual model will be based on ground-water levels, water chemistry, stream gains and losses, aquifer tests, surface and borehole geophysics, and test drilling. Analysis will include evaluation of conjunctive use of springs, wells, and surface-water sources of supply.

Progress: Eighty water-supply wells were inventoried. Seventeen wells were sampled for common inorganic chemical constituents, and 25 wells were sampled for inorganic constituents and trace elements. Thirty-three wells were sampled for tritium, oxygen-18, and deuterium. Thirty wells were sampled for Freon-11 and Freon-12, dissolved noble gases, carbon-14, chlorine-36, and uranium decay products. Two springs and two streams also were sampled for common inorganic constituents, Freons, and various isotopes and trace metals. Seepage runs were done on the South Fork Merced River and Rainier Creek to evaluate the interaction between streams and aquifers. Twenty seismic-refraction lines were run near Wawona Meadow to define the thickness of alluvial deposits, depth to the top of the unweathered granite surface, and fracture-caused anisotropy in the granitic rocks. Thirty-five, single-well aquifer tests were conducted. Linear features and fracture traces were mapped from aerial photographs.

Plans for Next Year: Additional single-well aquifer tests will be conducted, data from these tests will be analyzed, and the distribution of aquifer parameters will be compared to fracture-trace maps. Geochemical data will be evaluated for spatial trends. Several wells and springs will be selected for temporal monitoring of geochemical and biological constituents. A ground-water-level monitoring network will be established. Seepage runs on the South Fork Merced River and Rainier Creek will continue. Precipitation and streamflow data will be compiled. Selected wells will be geophysically logged to determine fracture locations, ground-water inflow points, and fracture hydraulic properties. Test wells may be drilled late in the fiscal year to calibrate the seismic refraction surveys in Wawona Meadow and to investigate production characteristics of wells on fracture traces.

Reports: None. 


\title{
WATER RESOURCES OF INDIAN RESERVATIONS IN CALIFORNIA
}

\author{
Number: CA487
}

Cooperating Agency: Pala Band of Mission Indians

Project Chief: James C. Blodgett

Period of Project: July 1990 to September 1993

Problem: About 40 small Indian reservations in California occasionally request assistance in assessing their reservation's water resources. The ability for the U.S. Geological Survey to respond to these requests is dependent on availability of qualified personnel. Commonly, this will involve a reconnaissance study to determine the potential of surface or ground water for development or simply to suggest sites where small supplies of good quality water can be found.

Objectives: Provide water-resource appraisals of Indian reservations in California. Because the reservations generally are small (some having only tens of people), the work to be done on each reservation will be limited to reconnaissance level, qualitative hydrology, and well-site selection. Where present or future potential water needs are large, areas beyond the reservation may be evaluated.

Approach: As necessary, wells will be inventoried, streams will be measured, water quality will be determined, and favorable sites for development will be located. Limited geologic mapping will be done if not already available. When warranted, shallow augering will be done, and if necessary, test holes may be drilled. Preliminary hydrologic models may be developed to assist in data analyses and interpretation.

Progress: During the first year of data collection, about 14 inches of rainfall and subsequent runoff were collected at the Bubble-up Creek gage near Pala to determine surface-water and water-quality characteristics of the basin. Two culverts, rated at about 45 cubic feet per second each, were used as control structures to gage the flows. The storm of February 28, 1991, produced a peak flow of about 130 cubic feet per second and consequently washed out the control structures. Channel control subsequently was used to gage the flows. A new structure will be built in mid-October to insure the stability of the channel banks. All available data were entered on the computer. A stage-discharge rating will soon be available, and work has begun on a rainfall-runoff model of the basin. The model will be used to determine storm characteristics of the basin using historical rainfall data as input. Rainfall-runoff data also was collected at Keys Creek at Valley Center to verify the data collected at Bubble-up Creek.

Water-quality samples were collected at three locations on Bubble-up Creek on March 8, March 18, and March 21, 1991, and were analyzed for major ions, nutrients, and selected trace elements. None of the concentrations exceeded the Environmental Protection Agency's safe drinking-water standards. However, concentrations as high as 9.9 milligrams per liter were measured for nitrate plus nitrite, as nitrogen. The drinking-water standard is 10 milligrams per liter.

Plans for Next Year: Stream and rain gages on Bubble-up Creek and Keys Creek Tributary will be operated during the year. The rainfall-runoff model for the Bubble-up Creek drainage basin will be calibrated and verified. The rainfall-runoff model, using historical rainfall data, will be used to determine the storm characteristics of the basin.

Reports: None. 


\title{
ASSESSMENT OF THE EFFECTS OF POTENTIAL CLIMATE CHANGE ON THE WATER RESOURCES OF THE CARSON AND AMERICAN RIVER BASINS
}

\author{
Number: CA488
}

Cooperating Agency: None. (U.S. Geological Survey Federal Program)

Project Chief: Michael D. Dettinger

Period of Project: March 1990 to September 1993

Problem: Changes in current climatic patterns could have significant effects on the type, amount, and timing of precipitation and runoff in the Carson and American River basins. Significant changes could result in farreaching effects on hydrologic processes, biota, water management, and water use.

Objectives: Define the effects of possible climate change on the water resources of the Carson and

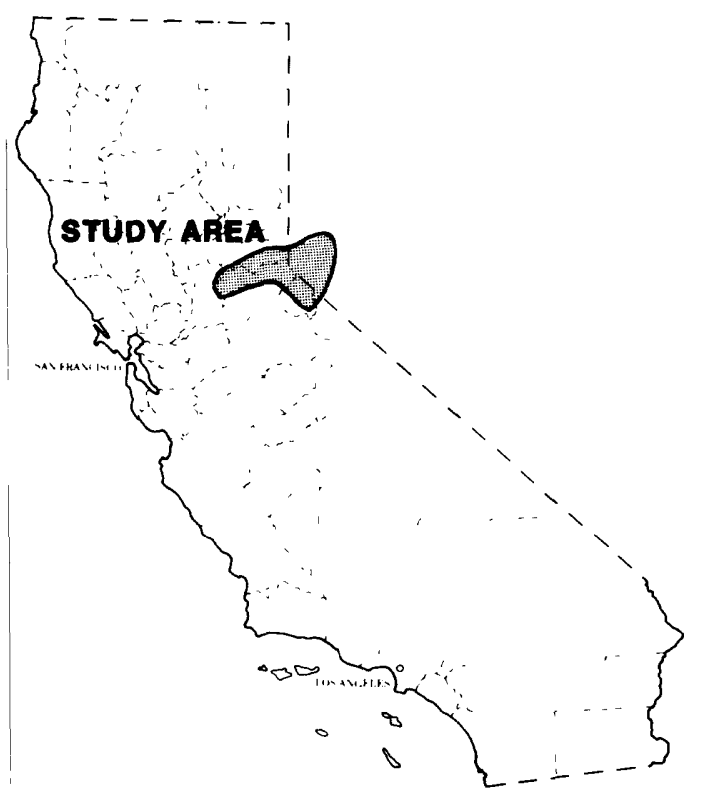
American River basins and develop analytical tools for analysis of the effects of climate change on water resources elsewhere.

Approach: The study will be a joint effort between the California and Nevada Districts. The general approach is to describe current climate and develop future climate scenarios, develop a data base to support watershed modeling and to develop a model of watershed processes for current and future scenarios. Specifically, project personnel in the California District will (1) link the unregulated streamflow for the basins to historical climate data on a stochastic analysis; (2) develop climate scenarios; and (3) analyze modeled streamflow responses to the scenarios.

Progress: (1) Analyses of winter circulation patterns over the Sierra Nevada were done, and recurring patterns were related stochastically to Sierra Nevada weather. A presentation describing the analyses was made at the 1991 American Geophysical Union (AGU) Fall Meeting, and a paper describing the analyses was begun.

(2) Year-round daily weather syntheses for the Carson and American Rivers were generated in support of Precipitation-Runoff Modeling System (PRMS) watershed modeling. The syntheses required derivation of an apparently new method for generating spatially correlated precipitation values. A technical note to document this new method is nearly completed.

(3) Multiple-regression analyses of streamflow in the American and Carson Rivers were completed, and the resulting models were used to test streamflow sensitivities to climate change. A paper describing these regression analyses and climate-change effects is in colleague review.

(4) An analysis of temperature variability across the United States was made at the University of California, Los Angeles in fiscal year 1990. Results were interpreted for the Sierra Nevada (CaliforniaNevada) and Gunnison (Colorado) climate-change study areas for a poster session at the USGS Global Change Research Forum in March 1991. Additional general results were presented to the National Oceanic Atmospheric Administration's 1991 Climate Diagnostic Workshop. 
Plans for Next Year: Papers in items 1 and 3 will be completed and submitted to refereed journals during fiscal year 1992, and presentations of results will be made at the 1992 Paclim Meeting and the 1992 American Water Resources Association Conference. Responses of the PRMS watershed models to long-term climate-change scenarios will be documented in a journal article and in a short project summary report presented to the 1991 NOAA Climate Diagnostics Workshop in October.

\section{Reports:}

Dettinger, M.D., 1991, A 40-winter chronology of 700-millibar atmospheric circulation patterns associated with warm-wet and cool-wet weather in the Sierra Nevada, California: Eos, Transactions of the American Geophysical Union, Abstracts, v. 72, no. 44, p. 156. 


\section{IRRIGATION DRAINAGE DETAILED STUDY OF KLAMATH BASIN, CALIFORNIA AND OREGON}

Number: CA489

Cooperating Agency: U.S. Department of the Interior

Project Chief: Vacant

Period of Project: October 1991 to September 1993

Problem: Results of a reconnaissance investigation done in 1988 indicate two major water-quality concerns that may effect aquatic environments within the Klamath Basin: (1) the effects of pesticide use and (2) excessive eutrophication on aquatic environments. This investigation also indicated a need for further study on the occurrence of arsenic and mercury in some biological tissues.

Objective: Determine if use of pesticides on agricultural lands adjacent to the Klamath Basin Wildlife Refuge is harming aquatic environments. Determine the relation between excessive eutrophication in the waterways and existing agricultural practices and the effects of the eutrophic conditions on aquatic environments.

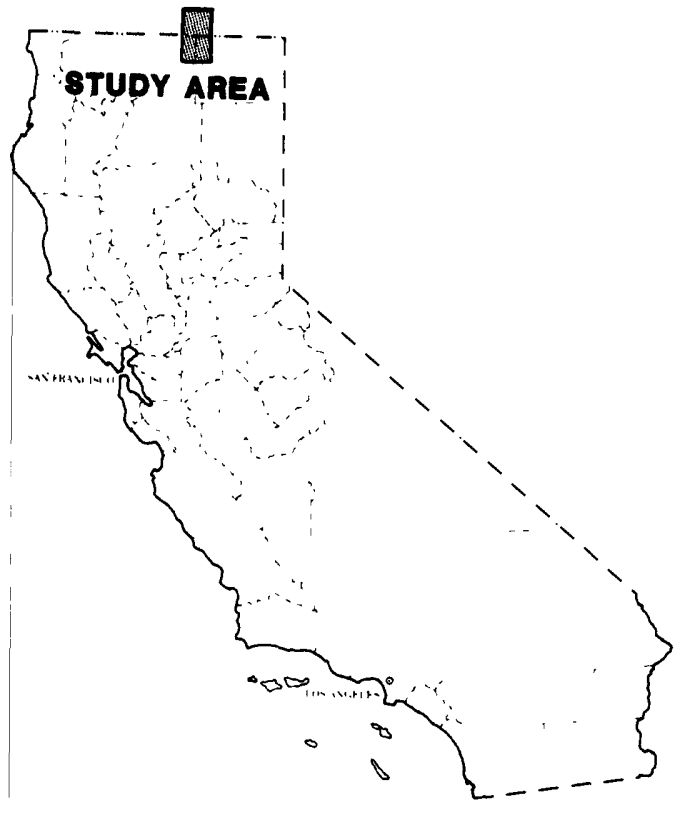

Approach: Effects of pesticides and eutrophication will be studied using various bioassays and chemical tests performed onsite or in a laboratory. Sampling stations will be located in and around the wildlife refuges and will represent end points for irrigation return flows, the most likely areas to contain detectable pesticides and to be effected by eutrophication. Static bioassays using Microtox (bacteria), algae, daphnia, amphipods, frog embryo, and fish and in situ bioassays using daphnia, amphipods, and fish will be done weekly. Water-quality measurements will be made with all bioassays. Water samples will be analyzed for organic pesticides.

Progress: During the 1991 field season, laboratory bioassays using Microtox, algae, daphnia, amphipods, frog embryo, and fish were run on water samples collected weekly at nine sites. A portion of this water was processed through solid-phase organic extraction cartridges for analysis of pesticides. In situ bioassays using daphnia, amphipods, and fathead minnows also were done weekly at each site.

Water-quality measurements for $\mathrm{Ph}$, conductivity, dissolved oxygen, and temperature were made with each visit to the sites. Ammonia was measured using an ion-specific electrode for all samples collected for laboratory bioassays and organic extraction. Benthic invertebrate samples were collected monthly at all nine bioassay sites. In August, diel studies were done at all nine bioassay sites plus three additional sites. Measurements were made every 2 hours for $\mathrm{Ph}$, conductivity, dissolved oxygen, and temperature; measurements were made every 4 hours for plant nutrients. Automatic monitors were deployed to supplement data collected with hand-held meters.

Eggs of western grebe, coot, white-faced ibis, and avocets were collected in June and July for analyses of trace elements. Phytoplankton samples were collected in September for analyses of trace elements. Western grebe eggs were collected for analyses of organochlorines to compare breeding areas.

Sediment samples were collected from the nine bioassay sites and from Tule Lake for chironomid bioassays. Porewater and solid-phase Microtox assays were done for sediment. 
An extensive pesticide-use data base was compiled that will be used to interpret the results of field sampling.

Plans for Next Year: Data collection will continue during 1992. Some modifications to the approach will be made after analysis of data from the first data collection.

Reports: None. 


\section{BIBLIOGRAPHY}

\section{REPORTS FOR CALIFORNIA PUBLISHED IN 1991}

Beard, Sherrill, Phillips, S.P., and Gilliom, R.J., 1991, Estimation of the constituent load of groundwater inflow to the San Joaquin River, California: Eos, Transactions of the American Geophysical Union, Abstracts, v. 72, no. 44, p. 187.

Berenbrock, Charles, and Martin, Peter, 1991, The ground-water flow system in Indian Wells Valley, Kern, Inyo, and San Bernardino Counties, California: U.S. Geological Survey Water-Resources Investigations Report 89-4191, 81 p.

Bertoldi, G.L., Johnston, R.H., and Evenson, K.D., 1991, Ground water in the Central Valley, California--A summary report: U.S. Geological Survey Professional Paper 1401-A, 44 p.

Blodgett, J.C., and Galloway, D.L., 1991, Measurement of land subsidence using GPS surveys: Edwards Air Force Base, Antelope Valley, California: Eos, Transactions of the American Geophysical Union, Abstracts, v. 72, no. 44, p. 118.

Bowers, J.C., Jensen, R.M., and Hoffman, E.B., 1991, Water resources data--California, water year 1990. Volume 1. Southem Great Basin from Mexican border to Mono Lake basin, and Pacific slope basins from Tijuana River to Santa Maria River: U.S. Geological Survey Water-Data Report CA-90-1, $289 \mathrm{p}$.

Chin, E.H., Aldridge, B.N., and Longfield, R.J., 1991, Floods of February 1980 in southern California and central Arizona: U.S. Geological Survey Professional Paper 1494, 126 p.

Crepeau, K.L., Kuivila, K.M., and Domagalski, J.L., 1991, Riverine inputs of pesticides to the Sacramento-San Joaquin Delta, California (abs.): Biennial International Conference of the Estuarine Research Federation, 11th, San Francisco Bay and Delta special session, San Francisco, November 10-14, 1991, Program.

Danskin, W.R., 1991, Advice and arbitration: The role of numerical models in the public sector (abs.): Geological Society of America, Cordilleran Section Meeting, 87th, San Francisco, March 25-27, Program.

Danskin, W.R., Farrar, C.D., and Dreiss, S.J., 1991, Ground-water basins along the eastern Sierra Nevada: Tectonics, water, and politics, in Walawender, M.J., and Hanan, B.B., eds., Geological excursions in southern California and Mexico: Geological Society of America, Annual Meeting, San Diego, California, 1991 Guidebook, p. 447-473.

Dettinger, M.D., 1991, A 40-winter chronology of 700-millibar atmospheric circulation patterns associated with warm-wet and cool-wet weather in the Sierra Nevada, California: Eos, Transactions of the American Geophysical Union, Abstracts, v. 72, no. 44, p. 156.

Deverel, S.J., and Fio, J.L., 1991, Groundwater flow and solute movement to drain laterals, western San Joaquin Valley, California. 1. Geochemical assessment: Water Resources Research, v. 27, no. 9, p. 2233-2246.

Domagalski, J.L., and Dubrovsky, N.M., 1991, Regional assessment of nonpoint-source pesticide residues in ground water, San Joaquin Valley, California: U.S. Geological Survey Water-Resources Investigations Report 91-4027, 64 p. 
Domagalski, J.L., and Kuivila, K.M., 1991, Transport and transformation of dissolved rice pesticides in the Sacramento River Delta, California, in Mallard, G.E., and Aronson, D.A., compilers, U.S. Geological Survey Toxic Substances Hydrology Program--Proceedings of the technical meeting, Monterey, California, March 11-15, 1991: U.S. Geological Survey Water-Resources Investigations Report 91-4034, p. 664-666.

1991, Transport and transformation of dissolved rice pesticides in the Sacramento River Delta, California, in Mallard, G.E., and Aronson, D.A., compilers, U.S. Geological Survey Toxic Substances Hydrology Program--Abstracts of the technical meeting, Monterey, California, March 11-15, 1991: U.S. Geological Survey Open-File Report 91-88, p. 117.

Domagalski, J.L., Kuivila, K.M., and Crepeau, K.L., 1991, Transport and transformations of dissolved and particle-bound pesticides in the San Francisco Bay Estuary, California (abs.): Biennial International Conference of the Estuarine Research Federation, 11th, San Francisco Bay and Delta special session, San Francisco, November 10-14, 1991, Program.

Dubrovsky, N.M., 1991, National Water-Quality Assessment Program--The San Joaquin-Tulare Basins: U.S. Geological Survey Open-File Report 91-153, 2 p. (Water Fact Sheet)

Dubrovsky, N.M., Neil, J.M., Welker, M.C., and Evenson, K.D., 1991, Geochemical relations and distribution of selected trace elements in ground water of the northern part of the western San Joaquin Valley, California: U.S. Geological Survey Water-Supply Paper 2380, 51 p.

Duell, L.F.W., Jr., and Kaehler, C.A., 1991, Ground-water data for San Nicolas Island, California, 1989-90: U.S. Geological Survey Open-File Report 91-197, 19 p.

Farrar, C.D., 1991, Hydrogeology of the interstratified volcanic rocks and glacial deposits in Mammoth basin, Mono County, California: Geological Society of America, Abstracts with program, v. 23, no. 5, p. 215.

Farrar, C.D., and Lyster, D.L., 1991, Hydrologic monitoring for effects of geothermal and ground-water development, Long Valley caldera, California, in Symposium on Subsurface injection of geothermal fluids, Santa Rosa, California, October 29-30, 1990, Proceedings: Oklahoma City, Oklahoma, Underground Injection Practices Council, p. 157-171.

Fio, J.L., and Deverel, S.J., 1991, Groundwater flow and solute movement to drain laterals, western San Joaquin Valley, California. 2. Quantitative hydrologic assessment: Water Resources Research, v. 27, no. 9 , p. $2247-2257$.

Fio, J.L., Fujii, Roger, and Deverel, S.J., 1991, Selenium mobility and distribution in irrigated and nonirrigated alluvial soils: Soil Science Society of America Journal, v. 55, no. 5, p. 1313-1320.

Fujii, Roger, and Dickson, A.T., 1991, Distribution of Se and As in ground water, Tulare basin, California (abs.): Soil Science Society of America, Annual Meeting, Denver, Colorado, October $27-$ November 1, 1991, Program.

Gilliom, R.J., 1991, Overview of sources, distribution, and mobility of selenium in the San Joaquin Valley, Califomia, chap. 3 in Dinar, Ariel, and Zilberman, David, eds., The economics and management of water and drainage in agriculture: Boston, Massachusetts, Kluwer Academic Publishers, p. 29-47.

Grillo, D.A., DeBortoli, M.L., and Lee, Arlyn, compilers, 1991, Activities of the Water Resources Division, California District, fiscal years 1988-90: U.S. Geological Survey Open-File Report 91-243, 116 p. (Published annually with various authorship and pagination.) 
Guay, J.R., 1991, Simulation of urban runoff and river water quality in the San Joaquin River near Fresno, California, in Jennings, M.E., ed., Urban Hydrology: Bethesda, Maryland, American Water Resources Association, p. 177-181.

Hollett, K.J., Danskin, W.R., McCaffrey, W.F., and Walti, C.L., 1991, Geology and water resources of Owens Valley, California: U.S. Geological Survey Water-Supply Paper 2370-B, 77 p.

Hunrichs, R.A., 1991, California floods and droughts, in National Water Summary 1988-89--Hydrologic events and floods and droughts: U.S. Geological Survey Water-Supply Paper 2375, p. 197-206.

1991, Droughts in California, 1987-90: U.S. Geological Survey Yearbook, Fiscal Year 1990, p. 57-60.

Hunter, T.C., Mullen, J.R., and Anderson, S.W., 1991, Water resources data--California, water year 1990. Volume 3. Southern Central Valley basins and The Great Basin from Walker River to Truckee River: U.S. Geological Survey Water-Data Report CA-90-3, 402 p.

Ikehara, M.E., 1991, Land subsidence in the Sacramento-San Joaquin Delta, California: U.S. Geological Survey Open-File Report 91-452, 2 p. (Water Fact Sheet).

1991, Repeat of GPS surveying to monitor land subsidence in Sacramento Valley, Califomia: Eos, Transactions of the American Geophysical Union, Abstracts, v. 72, no. 44, p. 118.

Izbicki, J.A., 1991, Chloride sources in a California coastal aquifer: American Society of Civil Engineers, Irrigation and Drainage Division Conference on Ground Water in the Pacific Rim Countries, Honolulu, Hawaii, July 23-25, Proceedings, p. 71-77.

Johnson, J.A., Fong-Frydendal, L.J., and Baker, J.B., 1991, Water resources data--California, water year 1990. Volume 5. Ground-water data for California: U.S. Geological Survey Water-Data Report CA- $90-5,387$ p.

Kaehler, C.A., and Hsieh, P.A., 1991, Hydraulic properties of a fractured-rock aquifer, Lee Valley, San Diego County, California: U.S. Geological Survey Open-File Report 90-592, 94 p.

Kuivila, K.M., and Domagalski, J.L., 1991, Organic contaminants in San Francisco Bay-Estuary (abs.): Geological Society of America, Cordilleran Section Annual Meeting, San Francisco, March 25-27, 1991, Program.

Kuivila, K.M., and Nichols, F.H., 1991, Overview of San Francisco Bay estuary toxic contaminants study, in Mallard, G.E., and Aronson, D.A., compilers, U.S. Geological Survey Toxic Substances Hydrology Program--Abstracts of the technical meeting, Monterey, California, March 11-15, 1991: U.S. Geological Survey Open-File Report 91-88, p. 116.

1991, Overview of San Francisco Bay estuary toxic contaminants study in Mallard, G.E., and Aronson, D.A., compilers, U.S. Geological Survey Toxic Substances Hydrology Program-Proceedings of the technical meeting, Monterey, California, March 11-15, 1991: U.S. Geological Survey Water-Resources Investigations Report 91-4034, p. 659-663.

Laudon, Julie, and Belitz, Kenneth, 1991, Texture and depositional history of late Pleistocene-Holocene alluvium in the central part of the western San Joaquin Valley, California: Bulletin of the Association of Engineering Geologists, v. 28, no. 1, p. 73-88.

Londquist, C.J., and Martin, Peter, 1991, Geohydrology and ground-water-flow simulation of the Surprise Spring basin aquifer system, San Bernardino County, California: U.S. Geological Survey Water-Resources Investigations Report 89-4099, 41 p. 
McCaffrey, W.F., and Rewis, D.L., 1991, Significance of lacustrine sediments underlying Edwards Air Force Base and vicinity, California, to ground-water movement: Geological Society of America, Abstracts with program, v. 23, no. 5, p. 27.

McFadden, M.C., Polinoski, K.G., and Martin, Peter, 1991, Measurement of streamflow gains and losses on Mission Creek at Santa Barbara, California, July and September 1987: U.S. Geological Survey Water-Resources Investigations Report 91-4002, 15 p.

Michel, R.L., Hamlin, S.N., and Phillips, S.P., 1991, Tritium distributions and recharge to ground water in western San Francisco, California: Eos, Transactions of the American Geophysical Union, Abstracts, v. 72, no. 44, p. 206.

Mitten, H.T., and Londquist, C.J., 1991, Documentation of model input and output values for the ground-water resources of Honey Lake Valley, Lassen County, California, and Washoe County, Nevada: U.S. Geological Survey Open-File Report 91-68, 5 p. (Supplement to WRIR 90-4050)

1991, Documentation of model input and output values for the geohydrology and ground-water flow simulation of the Surprise Spring basin aquifer system, San Bernardino County, California: U.S. Geological Survey Open-File Report 91-482, 5 p. (Supplement to WRIR 89-4099)

Mullen, J.R., Shelton, W.F., Markham, K.L., and Anderson, S.W., 1991, Water resources data--California, water year 1990. Volume 4. Northem Central Valley basins and The Great Basin from Honey Lake basin to Oregon State line: U.S. Geological Survey Water-Data Report CA-90-4, 323 p.

Neil, J.M., and Deverel, S.J., 1991, Atmospheric carbon input from decomposing peat soils of the Sacramento-San Joaquin Delta, California, in Global change and the biogeochemistry of radiative trace gases: International Symposium on Environmental Biogeochemistry, 10th, San Francisco, California, August 19-23, Abstracts, p. 30-31.

Nolan, K.M., and Hill, B.R., 1991, Suspended-sediment budgets for four drainage basins tributary to Lake Tahoe, California and Nevada, 1984-87: U.S. Geological Survey Water-Resources Investigations Report 91-4054, 40 p.

Phillips, S.P., Beard, Sherrill, and Gilliom, R.J., 1991, Estimation of the quantity and quality of groundwater inflow to the San Joaquin River, California: Eos, Transactions of the American Geophysical Union, Abstracts, v. 72 , no. 44 , p. 168.

1991, Quantity and quality of ground-water inflow to the San Joaquin River, California: U.S. Geological Survey Water-Resources Investigations Report 91-4019, 64 p.

Phillips, S.P., and Belitz, Kenneth, 1991, Calibration of a texture-based model of a ground-water flow system, western San Joaquin Valley, California: Ground Water, v. 29, no. 5, p. 702-715.

Reichard, E.G., and Martin, Peter, 1991, The role of ground-water modeling in the design of management plans for the control of seawater intrusion: Geological Society of America, Cordilleran Section Meeting, 87th, San Francisco, March 25-27, Abstracts with programs, p. 91.

Reichard, E.G., and Nishikawa, T., 1991, Management of seawater intrusion in Ventura County, California: A multistep simulation-optimization approach: Eos, Transactions of the American Geophysical Union, Abstracts, v. 72, no. 44, p. 201.

Rewis, D.L., and McCaffrey, W.F., 1991, Hydrogeologic evaluation of Edwards Air Force Base, California using geophysical data: Geological Society of America, Abstracts with program, v. 23, no. 5, p. 124. 
Rojstaczer, S.A., Hamon, R.E., Deverel, S.J., and Massey, C.A., 1991, Evaluation of selected data to assess the causes of subsidence in the Sacramento-San Joaquin Delta, California: U.S. Geological Survey Open-File Report 91-193, 16 p.

Schroeder, R.A., Setmire, J.G., and Densmore, J.N., 1991, Use of stable isotopes, tritium, soluble salts, and redox-sensitive elements to distinguish ground water from irrigation water in the Salton Sea basin, in Ritter, W.F., ed., Irrigation and Drainage: American Society of Civil Engineers National Conference on Irrigation and Drainage, Honolulu, Hawaii, July 22-26, Proceedings, p. 524-530.

Shelton, L.R., and Miller, L.K., 1991, Water-quality data, San Joaquin Valley, California, April 1987 to September 1988: U.S. Geological Survey Open-File Report 91-74, 189 p.

Shelton, W.F., Trujillo, L.F., Markham, K.L., and Palmer, J.R., 1991, Water resources data--California, water year 1990. Volume 2. Pacific slope basins from Arroyo Grande to Oregon State line except Central Valley: U.S. Geological Survey Water-Data Report CA-90-2, 333 p.

Smith, P.E., Cheng, R.T., Burau, J.R., and Simpson, M.R., 1991, Gravitational circulation in a tidal strait: American Society of Civil Engineers, National Conference on Hydraulic Engineering, Nashville, Tennessee, July 29-August 2, Proceedings, p. 429-434.

Sorenson, S.K., Dileanis, P.D., and Branson, F.A., 1991, Soil water and vegetation responses to precipitation and changes in depth to ground water in Owens Valley, California: U.S. Geological Survey Water-Supply Paper 2370-G, 54 p.

Yates, E.B., 1991, Droughts in a stream-aquifer system, San Simeon Creek, California, in Kirby, W.H., and Tan, W.Y., compilers, Proceedings of the United States--People's Republic of China bilateral symposium on droughts and arid-region hydrology, September 16-20, 1991, Tucson, Arizona: U.S. Geological Survey Open-File Report 91-244, p. 331-336. 


\section{SOURCES OF WRD PUBLICATIONS AND INFORMATION}

Publications of the U.S. Geological Survey (USGS):--Professional Papers, Water-Supply Papers, Bulletins, Circulars, Water-Resources Investigations Reports, and Open-File Reports are sold by the U.S. Geological Survey, Books and Open-File Reports Section, Federal Center, Box 25425, Denver, CO 80225. Hydrologic Investigations Atlases, Hydrologic Unit Maps, and other maps pertaining to California are sold by the U.S. Geological Survey, Map Distribution Section, Federal Center, Box 25286, Denver, CO 80225.

U.S. Geological Survey Water-Resources Investigations Reports and Open-File Reports are available for inspection at the California District Office, U.S. Geological Survey, Federal Building, Room W-2233, 2800 Cottage Way, Sacramento, CA 95825, and U.S. Geological Survey, 5735 Kearny Villa Road, Suite O, San Diego, CA 92123. Information on their availability may be obtained from the District Chief at the above address.

New reports are announced monthly in "New Publications of the Geological Survey," subscriptions to which are available upon request from the U.S. Geological Survey, 582 National Center, Reston, VA 22092.

Water-Data Program:--Water-data stations at selected locations throughout the Nation are used by the Geological Survey to obtain records on stream discharge (flow) and stage (height), reservoir and lake storage, ground-water levels, well and spring discharge, and the quality of surface and ground water. These data provide a continuing record of the quantity and quality of the Nation's surface- and ground-water resources, and thus provide the hydrologic information needed by Federal, State, and local agencies and the private sector for the development and management of land and water resources. All data collected are stored in the Survey's National Water Data Storage and Retrieval System (WATSTORE) and also are published by water year for each State in a publication series entitled "U.S. Geological Survey Water Resources Data." Information about the Water-Data Program can be obtained from the California District Chief.

NAWDEX:--The National Water Data Exchange was established to assist users of water data to identify, locate, and acquire needed data. It provides a nationwide service for indexing and describing the characteristics of data available from the entire spectrum of data-collection activities throughout the Federal and non-Federal water-data community.

NAWDEX maintains two data bases: (1) a Water-Data Sources Directory and (2) a Master Water-Data Index which identifies and describes available water data. NAWDEX sources can be obtained from the California District Chief. A leaflet explaining NAWDEX services is available from the NAWDEX Program Office, U.S. Geological Survey, 421 National Center, 12201 Sunrise Valley Drive, Reston, VA 22092; phone: (703) 648-5677. 


\section{WHERE TO OBTAIN ADDITIONAL INFORMATION ON}

\section{U.S. GEOLOGICAL SURVEY PROGRAMS}

WATER

California District

U.S. Geological Survey

2800 Cottage Way

Room W-2233, Federal Building

Sacramento, CA 95825

Phone: (916) 978-4643
MAPPING

National Cartographic Information Center

U.S. Geological Survey

345 Middlefield Road, MS 532

Menlo Park, CA 94025

Phone: (415) 329-4353

\section{GEOLOGY}

Assistant Chief Geologist

U.S. Geological Survey

345 Middlefield Road, MS 919

Menlo Park, CA 94025

Phone: (415) 329-5101

\section{WHERE TO OBTAIN ADDITIONAL INFORMATION ON U.S. GEOLOGICAL SURVEY REPORTS}

Earth Science Information Center

U.S. Geological Survey

345 Middlefield Rd., MS 532

Menlo Park, CA 94025

Phone: (415) 329-4390 (to purchase publications)

Phone: (415) 329-4309 (to obtain historical information)

FOR MAIL ORDERS

BOOKS

U.S. Geological Survey

Books and Open-File Reports Section

Federal Center

Box 25425

Denver, CO 80225
MAPS

U.S. Geological Survey

Map Distribution Section

Federal Center

Box 25286

Denver, CO 80225 